\title{
Access to Collateral and The Democratization of Credit: France's Reform of The Napoleonic Security Code
}

DOI:

10.1111/jofi.12846

\section{Document Version}

Accepted author manuscript

Link to publication record in Manchester Research Explorer

\section{Citation for published version (APA):}

Aretz, K., Campello, M., \& Marchica, M. (2020). Access to Collateral and The Democratization of Credit: France's Reform of The Napoleonic Security Code. Journal of Finance, 75(1), 45-90. https://doi.org/10.1111/jofi.12846

\section{Published in:}

Journal of Finance

\section{Citing this paper}

Please note that where the full-text provided on Manchester Research Explorer is the Author Accepted Manuscript or Proof version this may differ from the final Published version. If citing, it is advised that you check and use the publisher's definitive version.

\section{General rights}

Copyright and moral rights for the publications made accessible in the Research Explorer are retained by the authors and/or other copyright owners and it is a condition of accessing publications that users recognise and abide by the legal requirements associated with these rights.

\section{Takedown policy}

If you believe that this document breaches copyright please refer to the University of Manchester's Takedown Procedures [http://man.ac.uk/04Y6Bo] or contact uml.scholarlycommunications@manchester.ac.uk providing relevant details, so we can investigate your claim.

\section{OPEN ACCESS}


$\operatorname{xxxxxxxx-T}$

\title{
Access to Collateral and The Democratization of Credit: France's Reform of The Napoleonic Security Code
}

\author{
KEVIN ARETZ, MURILLO CAMPELLO and MARIA-TERESA MARCHICA*
}

\begin{abstract}
France's Ordonnance 2006-346 repudiated the notion of possessory ownership in the Napoleonic Code, easing the pledge of physical assets in a country where credit was highly concentrated. Using a differences-test strategy, we show that firms operating newly-pledgeable assets significantly increased their borrowing following the reform. Small, young, and financially constrained businesses benefitted the most, observing improved credit access and real-side outcomes. Start-ups operating newly-pledgeable assets emerged with higher "at-inception" leverage, located farther from large cities, with more assets-in-place than before. Their exit and bankruptcy rates declined. Spatial analyses show that the reform reached firms in rural areas, reducing credit access inequality across France's countryside.
\end{abstract}

*Kevin Aretz: Alliance Manchester Business School, Booth Street, Manchester M15 6PB, UK, tel.: +44(0)161 275 6368, e-mail: kevin.aretz@manchester.ac.uk; Murillo Campello (corresponding 
author): Cornell University and NBER, Johnson Graduate School of Management, Cornell University, 369 Sage Hall, Ithaca, NY 14853, tel.: +1(0) 607255 1282, e-mail: campello@cornell.edu; Maria-Teresa Marchica: Alliance Manchester Business School, Booth Street, Manchester M15 6PB, UK, tel.: +44(0)161 275 0121, e-mail: maria.marchica@manchester.ac.uk. We are indebted to two anonymous referees, an anonymous associate editor, and the managing editor (Amit Seru) for helpful and constructive suggestions. We are also indebted to Manuel Adelino, Nittai Bergmann, Charles Calomiris, Gilles Chemla, Alberta Di Giuli, Mara Faccio, Laurent Frésard, Edith Ginglinger, Gaurav Kankanhalli, Mauricio Larrain, Kai Li, Ulf Lilienfeld-Toal, Noel Maurer, Roni Michaely, Matteo Millone, Abhiroop Mukherjee, Giovanna Nicodano, Steven Ongena, Maurizio Pisati, Zacharias Sautner, Reinhard Schmidt, Antoinette Schoar, David Thesmar, Giuseppe Vittucci, and Baolian Wang for their constructive and helpful insights. Comments from participants at the 2015 European Finance Association Meetings (Vienna), the 14th International Conference on Credit Risk Valuation (Venice), the 7th European Banking Center Conference (Tilburg), the 2016 Edinburgh Corporate Finance Conference, the 2016 Financial Intermediation Research Society (FIRS) Conference (Lisbon), the 2016 UBC Summer Finance Conference (Vancouver), the 2016 Western Finance Association Meetings (Park City), the 2018 Finance, Organizations, and Markets (FOM) Conference (Hanover), the 2018 Mitsui Symposium on Comparative Corporate Governance and Globalization (Ann Arbor), as well as seminar participants at American University, Birmingham University, Bristol University, Columbia University, ESCP Paris, the Free University of Bozen, IDC Herzliya, Paris-Dauphine University, St. Andrews University, Strathclyde University, and WHU Koblenz are also acknowledged. We are grateful to Marie-Elodie Ancel from Université Paris Est Créteil, Giuliano Castellano from University 
of Hong Kong, Rod Cork from Allen \& Overy (Paris), and Philip Wood from Allen \& Overy (London) for insightful discussions about French laws; and Annalisa Ferrando from the European Central Bank for sharing the SAFE index. We have read the Journal of Finance's disclosure policy and have no conflicts of interest to disclose. 
"To allow for a more equal access to credit, I wish to see a rapid easing of the pledge regime.

Do I need to remind you that currently a borrower, for example, a company, has to hand over the property that it pledges? Do you know a modern country that works that way?"

- Pascal Clément, Minister of Justice, addressing the French Parliament on June 22, 2005.

Several countries use security laws derived from the Napoleonic Code, a regime predicated on the notion of "possessory ownership." Under the highly-formalized, centuries-old Code, physical assets are deemed to be "unique," "whole," and "non-transferrable" (see Omar (2007) and Ancel (2008)). These legal fictions ultimately limit the types of security interests that can be written on productive assets and favor large, established, well-connected incumbents over small, young, innovative newcomers (see, e.g., Fleisig, Safavian, and de la Peña (2006)). Institutional arrangements of this kind have detrimental consequences for financial markets and economic development, but the critical mechanisms that underlie these connections and their reach — are not fully understood. This paper shows how a recent reform in France informs knowledge about links between the legal contracting framework, access to credit (level and distributional effects), business formation, and real economic outcomes.

Ordonnance 2006-346 derogated the notion of possessory asset ownership in France, in existence since 1804. By doing so, the 2006 reform allowed French firms to control and operate (in-house) physical assets pledged to third parties. This seemingly simple statutory change significantly enlarged the menu of assets that firms could pledge in credit transactions, particularly hard movable assets used in modern business operations (such as machinery and equipment). In addition to expanding the set of assets that could be collateralized, the new regime allowed 
for security interests to be charged to more than one party, making it feasible for loans to be syndicated under multiple creditors, with multiple priority schemes, and multiple maturity structures. In further allowing for rechargeable interests, the reform also critically enhanced the pledgeability of hard immovable assets (land and buildings). The new law had no bearing on firms' ability to offer liquid assets as collateral. Notably, Ordonnance 2006-346 did not introduce changes related to the balance of power between contracting parties, asset seizure procedures, or judicial intervention. This starkly differentiates it from most other credit reforms, which have promoted the notion of "strengthening creditors' rights" as a way to ease credit access.

The wrinkles in the process through which France reformed its security code system allow for unique insights into the distributional and wealth effects of easing access to collateral. Changing the legal framework governing asset ownership and alienability meant that firms were discretely, yet differentially endowed with "new assets" that they could pledge in credit transactions. Nesting pairwise-matching in difference-in-differences (DID) estimations, we build on the prior that firms whose operations relied most intensely on hard assets could be favored by a reform that distinctly enhanced their ability to pledge that class of assets in credit agreements. In this setting, we contrast and compare firms according to the types of assets more intensely used in their production processes (hard versus liquid), according to the nature of the contracts they sign (short- versus long-term), their size, age, and credit access status ("financing constraints"), among several dimensions that help us trace how access to collateral shapes credit taking and corporate outcomes. We also gauge larger economic consequences of this process, including spatial reach and allocation efficiency. Amongst the most innovative margins we consider is the impact of the collateral reform on start-ups, assessing effects that speak to the issues of business formation, growth, and survival. 
We first study the effect of Ordonnance 2006-346 on firm credit using comprehensive data from Bureau van Dijk. We find that the reform significantly increased the debt-taking of French firms with no access to public markets along both the intensive margin (leverage ratios) and the extensive margin (propensity to take out any debt at all). Notably, the reform only affected long-term debt-taking (secured by hard assets). Using firms' fixed assets intensity to identify effect heterogeneity, we show that the increase in debt ratios and the decline in the proportion of "zero-leverage" firms occurred primarily among "high-fixed assets intensity" firms. In particular, while the long-term leverage ratio of high-fixed assets firms rose about 7 percentage points after the reform, the long-term leverage ratio of low-fixed assets firms rose by a mere 1 point. The $6 \%$-point difference is remarkable when compared to the pre-reform average leverage ratio of only 1.4\%. Confirming the logic of our test, short-term debt (which is not secured by hard assets) did not change across high- or low-fixed assets firms. All of the tests we perform have firms matched on several pre-determined dimensions and account for firm- as well as industry-year-fixed effects.

After establishing that firms operating assets contemplated by the 2006 collateral-menu reform are able to issue more secured debt, we look into a number of real-side outcomes. This is an important examination since previous work on credit expansion has warned researchers and policy-makers about credit that is indiscriminately awarded to "marginal borrowers" in the economy. ${ }^{1}$ We examine three sets of real outcomes in our matched-difference-in-differences tests: firm spending, performance, and risk. Regarding the first set, we find that high-fixed

\footnotetext{
${ }^{1}$ Assunção, Benmelech, and Silva (2014), for example, study a reform in Brazil that simplified the sale of repossessed cars used as collateral for auto loans. That reform led to higher credit availability and taking. However, it distinctively allowed for riskier borrowers to obtain loans for more expensive cars, ultimately triggering higher default rates.
} 
assets firms spent significantly more in capital investment and labor employment after the collateral reform. Regarding the second, we find that those same firms observed higher sales and profitability rates in the years following the reform. Finally, we document that high-fixed assets firms observed a significant decline in profit volatility and, ultimately, a comparatively lower probability of filing for bankruptcy after the reform. Our analysis suggests that the 2006 collateral reform benefitted seemingly promising, creditworthy borrowers.

Our next step is to study whether the reform reached firms previously rationed in the credit market ("credit democratization"). We perform several sets of analyses on this front. We first break out our main tests across characteristics that commonly speak to firms' ability to access credit. In particular, we look at whether the collateral reform had significantly differential effects on firms that are small (proxied by asset size and workforce), young (years in operation), or are classified as financially constrained according to a French-specific index of financial constraints based on the European Central Bank (ECB)/European Commission (EC) Survey on Access to Finance of Enterprises (SAFE). A matching-triple-differences test approach shows that these likely credit-rationed firms gained the most access to credit following the repudiation of possessory ownership. As an example, the average increase in the leverage ratios of high-fixed assets firms employing less than 35 employees (bottom quartile of the employment distribution) was twice as high as the leverage increase of high-fixed assets firms with more than 165 employees (top quartile of employment). Similar figures are attached to estimations across samples of firms classified as financially constrained in France vis-à-vis firms that do not fall into that classification. Under the same testing framework, we look at the real outcomes we considered for our aggregate sample (spending, performance, and risk). Our tests show that investment, hiring, sales, and profitability 
were particularly positively affected by the reform among high-fixed assets firms that were small, young, and financially constrained. At the same time, those subsets of firms were differentially more likely to observe reductions in profit volatility and failure rates.

Our base results suggest that Ordonnance 2006-346 helped democratize credit access toward existing firms that likely starved for the funding of viable projects. Yet, the proceeding analysis left out a margin that is often ignored in the examination of credit reforms: the establishment of new firms. We pursue such an examination using additional data from Bureau van Dijk and from the French Census (INSEE). In these tests we are able to match start-ups in the same industry, incorporated in the same year, and located in the same French department.

We first show that "at-inception" leverage ratios of start-up businesses operating more fixed assets increased significantly more following the collateral reform than the leverage ratios of industry-year-location-matched start-ups operating less fixed assets. For instance, the average leverage of high-fixed assets start-ups incorporated after 2006 was 13 percentage points higher than that of similar start-ups incorporated before 2006; this compared to only 5 points higher for low-fixed assets start-ups over the same time window. Next, we dig deeper into post-reform outcomes for start-ups, assessing the reform's impact on metrics that gauge business formation, growth, and survival. Among other results, we show that, after the collateral reform, start-ups operating more fixed assets were geographically born farther away from France's large cities; where access to finance is scarce, and when available, complicated by frictions commonly associated with physical distance between borrowers and financial providers (see, e.g., Agarwal and Hauswald (2010)). We also show that the initial size of start-ups operating more fixed assets increased with the reform (from US\$99 to US\$115 thousand, on average). In contrast, the size 
of industry-year-location-matched start-ups operating fewer fixed assets did not change. Our estimations also show that high-fixed assets start-ups grew faster after the collateral reform; this while the growth rate of matched low-fixed assets start-ups declined. Finally, we look at general exit and bankruptcy rates for start-ups in France around the reform as a function of those firms' fixed-asset usage. General exit and bankruptcy rates of high-fixed assets start-ups became markedly lower than those of low-fixed assets start-ups after Ordonnance 2006-346 (those rates were indistinguishable prior to the reform). ${ }^{2}$

We also look at the issue of credit democratization via a geography-based analysis of the reform's effects. Several studies emphasize the importance of firm location in accessing credit (e.g., Hauswald and Marquez (2006), Agarwal and Hauswald (2010), and Granja, Leuz, and Rajan (2018)). A higher density of financial institutions, in particular in and around urban centers, lowers the informational cost of credit acquisition (e.g., DeYoung, Goldberg, and White (1999)). As such, firms located in rural areas face a significant disadvantage in accessing credit (e.g., Arena and Dewally (2012)). Using spatial-point analyses, we show that firms located away from metropolitan areas gained the most credit access from the collateral reform. We also compute a Gini index of corporate credit to gauge whether the reform reduced inequality in credit access within and across different jurisdictions in France. Before the reform, 90 out of 96 French departments had a Gini index exceeding 0.90, implying that the credit market in virtually every department was dominated by a handful of large firms. ${ }^{3}$ After the reform, only 19 departments registered an

\footnotetext{
${ }^{2}$ Our collateral-menu reform evidence is in tandem with findings by Schmalz, Sraer, and Thesmar (2017) showing that increases in home collateral values lead to increases in the probability of becoming an entrepreneur in France.

${ }^{3}$ France's Gini index of corporate credit inequality was 0.95 before 2006, a high figure when compared to 0.82
} 
index above 0.90. Remarkably, the largest drops occurred in rural departments, far from the main French urban areas and financial centers. The geography-based analysis we present adds to the understanding of how economic policy percolates throughout a country, providing perspective to decision-makers concerning their policy goals.

We end our study tracing the economic effects of the reform at the macro level. We run two sets of tests on this front. First, following Wurgler (2000), we use the sensitivity of capital investment growth to value added growth as metric of the efficiency of the cross-sectoral capital allocation process within a country. Wurgler's efficiency sensitivity metric jumped from 0.48 to a post-reform level of 0.85. Notably, this increase in allocation efficiency was particularly more pronounced across industries with a larger fraction of high-fixed assets firms. We also use the external financing dependence proxy of Rajan and Zingales (1998) as an additional capital allocation efficiency metric. The reform raised long-term borrowing more pronouncedly in sectors that were more highly dependent on external financing. These results, too, are more significant for subsamples of small, young, and financially constrained firms. The bulk of our evidence suggests that the reform-induced changes to France's collateral regime improved that country's capital allocation process.

Our study contributes to the Law and Finance literature on various fronts. Most of the existing studies analyze cross-country bankruptcy regime differences (LaPorta et al. (1998) and Djankov, McLiesh, and Shleifer (2007)) or within-country bankruptcy regime changes (LilienfeldToal, Mookherjee, and Visaria (2012) and Vig (2013)). Our focus, instead, is on collateral contracting, which carries different policy implications. We show how collateral regime changes may spur the democratization of credit, allowing small, young, profitable, start-up firms, and firms located in in other comparable European Civil Law countries (Belgium, Italy, Portugal, and Spain). 
the countryside to access new credit facilities. We also show how collateral regime changes may bring about positive real-side implications at both micro and macroeconomic levels. Critically, these outcomes can be achieved dispensing with the need to introduce often controversial and costly changes to the legal powers of contracting parties or changes to rules governing judicial intervention.

Our study also adds to recent research looking at how collateral affects bank credit. Cerqueiro, Ongena, and Roszbach (2016) show that reductions in collateral values may trigger increases in loan interest rates and reductions in credit limits. Calomiris et al. (2017) show that bank lending secured with movable assets is lower in countries with weaker collateral protection. Our study is different in that we focus on firms rather than banks, allowing us to make inferences about real-side implications of collateralized debt-taking. Closer to our paper, Campello and Larrain (2016) look at a collateral regime change in an emerging market (Romania). In contrast to their paper, our setting and data allow us to study the effects of collateral on several key, deeper dimensions, such as start-ups' access to credit, firm survival, financial constraints, and economy-wide capital allocation. In addition, the spatial analyses we employ provide new insights into the regional dynamics of credit access distribution within a country.

Our paper is also related to the literature linking credit and economic development. Prior studies show that credit expansion may trigger waves of defaults and repossessions (White (2007), Keys et al. (2010), Mian and Sufi (2010), and Assunção, Benmelech, and Silva (2014)). Others show that credit easing may lead to more business entry and higher economic activity (Benmelech and Moskowitz (2010) and Chatterji and Seamans (2012)). We add to this literature by showing how collateral-induced credit creation may shape the capital allocation process. Our analysis shows that when and where credit markets become "deeper" due to an enhanced 
ability to pledge collateral, not only do existing firms use more external credit as a result, but new firms, too, use more debt than before at the start of their operations.

The balance of our article is organized as follows. Section I discusses the French collateral reform. Section II describes our data and empirical methodology. Section III studies the overall effects of the reform on credit access and real-side variables. Section IV discusses credit democratization. Section $\mathrm{V}$ focuses on business formation, growth, and survival (start-up firms). Section VI examines capital allocation efficiency. Section VII contains a series of robustness checks. Section VIII concludes.

\section{Institutional Setting: Security Laws in France}

\section{A. The Napoleonic Code of 1804}

Until recently, security interests in France were governed by the 1804 Napoleonic Code. The codified system was predicated on the notion that borrowers had to be protected from exploitative creditors, while creditors had to be protected from borrowers refusing the surrender of collateral in default. To reconcile these interests, regulators established highly formal, costly procedures for the creation of security rights. As such, the 1804 Code would not recognize non-possessory charges since assets pledged without dispossession could lead future creditors to "misapprehend a borrower's creditworthiness" (see Haimo (1983)). ${ }^{4}$ Ruling out non-possessory charges meant that borrowers had to physically transfer pledged assets for creditors to validate — in the legal jargon,

\footnotetext{
${ }^{4}$ The refusal to recognize non-possessory charges is grounded in the centuries-old notion that only the physical possession of assets would unequivocally demonstrate a borrower's creditworthiness.
} 
"perfect" - a security interest. This statute of the law had profound implications for borrowing. It implied that firms could not pledge assets to third parties while at the same time continuing to freely use and dispose of those assets in their regular (in-house) operations. Because assets were also deemed as "unique" and "non-substitutable" under the Napoleonic Code, firms could not offer similar assets in securing a credit transaction. Security interests over "fungible assets" (such as oil, steel, etc.) or "future assets" (such as machinery and equipment under construction, or inventory in process) were also disallowed because such assets could not be easily identified and physically transferred to creditors. Finally, the Code would not recognize rechargeable mortgages ("hypothecs") since these could lead to conflicts about priority (see Ancel (2008)).

The 1804 Code focused on interests over land. In the early $19^{t h}$ century, the French economic system was centered around land-based activities and lawmakers deemed interests over other production assets as "of little relevance" (see Omar (2007)). As the need for modern financing demanded new securitization techniques, the legislature filled gaps in the law over the years with ad hoc regulation (Haimo (1983)). By the end of the 1990's a total of ten different non-possessory security interests were legally identifiable, each of them pertaining to specific branches of trade or industry (see Goode (1974) and Kieninger (2004)). ${ }^{5}$ Even for those industries, however, a number of aspects of non-possessory interests rendered them as ineffective in accessing credit. For example, as for equipment liens, interests could only be taken out if the borrowed money was used to acquire new equipment (equipment already in place could not serve as collateral). Notably, holders of those liens were junior to a number of other creditors in bankruptcy. Perhaps most trou-

\footnotetext{
${ }^{5}$ Examples include non-possessory security interests issued to the wine industry following the devastating phylloxera plague of the 1860's and to the French moviemaking industry in the 1940's.
} 
bling were difficulties in ascertaining the very definition of equipment. Each one of the existing classes of non-possessory interests had their own independent definition of "securitizable assets."

The cumulative effect of this approach was a lack of consistency in requirements for creating and perfecting security interests over different types of assets. As a result, security interests over fixed assets were hardly ever used. This is made clear by evidence in Davydenko and Franks (2008), who show that less than $20 \%$ of assets pledged as collateral before the 2006 reform were comprised of hard assets such as real estate or machinery and equipment (see Panel A of Table VI of their paper). Likewise, alternative sources of financing not requiring collateral, such as sale-leaseback, and more generally, leasing agreements, were not commonly used in France during that time. This has been attributed to the strong protection afforded to lessees regarding the termination and renewal of lease agreements (see Haimo (1983)). ${ }^{6}$ On average, only $11 \%$ of the country's total gross fixed investment was funded through leasing. This figure is small when compared to $26 \%$ for the US, $17 \%$ for Germany, and $13 \%$ for other European Civil Law countries (see Leaseurope (2009) and White Clark Group (2015)).

\section{B. Reforming the Napoleonic Code: Ordonnance 2006-346}

In the early 2000's, France's outdated security laws became a topic of much policy debate (see Renaudin (2013)). In March 2005, President Chirac asked the Minister of Justice to reform the country's security regime. In June, the French Parliament passed Law 2005-842 on "Trust

\footnotetext{
${ }^{6}$ For example, at the expiration of a commercial lease, the lessee is entitled to an additional term of 9 years provided the lessee has occupied the premises for 3 years. In the US and German systems, in contrast, lessees are only entitled to a new lease at expiration when that option was part of the original agreement; lessors are not obliged to pay any compensation (Lofstedt and Baum (1993)).
} 
and Modernization of the Economy," enabling the government to reform security laws by way of Ordonnance (government order). Under this exceptional mandate, the central government could pass laws on economic matters without further congressional approval. In March 2006, the French government enacted a sweeping reform of the country's security laws.

Ordonnance 2006-346 transformed the law and practice of secured credit transactions in France (Ancel (2008), Renaudin (2013), Castellano (2015), and Riffard (2016)). The reform repudiated the notion of possessory ownership by stating that a charge could be created on any present or future, tangible or intangible, or group of movable assets (Articles 2333 and 2355), provided they could be identified through a written description (Article 2336). The new non-possessory charges were given legal priority over pre-existing possessory charges. Notably, the reform also improved the status of security over immovable assets by allowing rechargeable mortgages. That meant that existing and new mortgages would allow for sequential addition of new creditors, who could be granted rights that were more equal to those of pre-existing lien holders. The rechargeability feature significantly improved the use of immovable assets, such as real estate, as collateral in loan contracts (Omar (2007)).

The new law did not introduce "floating charges" (charges applying to the "general collection" of corporate assets). As such, the formal identification of assets legally recognizable and eligible for collateralized charges remained a key issue for credit access (see Herbet and Sabbah (2006) and Ancel (2008)). This is important for our empirical analysis of the collateral law since this asset-specific eligibility feature (that only concerns movable and immovable fixed assets) can be observed and thus used for test identification. 


\section{Other Law Changes}

Countries reforming their financial architecture often reconsider several existing institutions at the same time. One year before Ordonnance 2006-346, a regulation was introduced in order to allow for preventive resolution of firms' financial difficulties prior to insolvency. The "2005 Safeguard Provision" had ambiguous provisions regarding the bankruptcy process. On the one hand, it made it easier for managers to strategically file for bankruptcy. On the other hand, it gave new powers to creditors in bankruptcy court, such as the appointment of creditors' representatives and inspectors to assist creditors and judges. ${ }^{7}$

By all tangible accounts, the 2005 provision failed to achieve its goals (see, e.g., Plantin, Thesmar, and Tirole (2013)). Government statistics show that less than 500 safeguard procedures opened in each of the first two years after the rule was passed. This figure dwarfs in comparison to about 2,500 standard fillings for in-court resolution recorded annually over the same period (Omar (2014)). Such regulatory failure was so flagrant that it prompted the French Government to reform the 2005 provision several years later (see Plantin, Thesmar, and Tirole for additional discussion). Potential confounding effects of the 2005 provision with Ordonnance 2006-346 seem improbable. ${ }^{8}$

\footnotetext{
${ }^{7}$ Creditor-appointed inspectors retained the right to review any documents they wished to procure and the right to bring actions against the debtor, including claims for fraudulent conveyance. For larger companies (above 250 employees), creditors were represented by two committees, one for financial institutions and another for trade creditors.

${ }^{8}$ To further separate the effects of the two regulations we designed a robustness check for our results on a subsample of French firms unaffected by the 2005 Safeguard Provision (those with less than 150 employees, which account for over $70 \%$ of our sample). Results in Table IA.I in the Internet Appendix show that the 2005 provision has no impact on our inferences.
} 
The 2006 reform itself had originally also aimed at strengthening creditors' rights by lifting a ban on out-of-court seizures of collateral in default. However, the French Parliament appointed two separate groups — accountable to different branches of government — to modernize security laws and bankruptcy laws. No effort was made to ensure that reforms in the two areas would be synchronized. As such, several years after the 2006 reform, the bankruptcy code still suspended a creditor's right to seize collateral out-of-court. The failure to strengthen creditors' rights makes Ordonnance 2006-346 unique: a reform that enlarged the contracting space without altering the balance of power between contracting parties, seizure procedures, or court involvement.

\section{Non-Codified Security Laws and Identification Strategy}

Managers of large companies in major French cities had long recognized that the 1804 Security Code was outdated and costly to work with. In the 1970's and 1980's, their concerted lobbying spurred regulation on securitization practices that were purposefully not added to the Napoleonic Code. ${ }^{9}$ The most popular of these "non-codified laws" were the Dailly Law and the Pledge of Ready Money. The Dailly Law allowed firms to assign their receivables to non-banking financial institutions in securitizing debt contracts. The Pledge of Ready Money allowed them to do the same using cash and cash equivalents. Both laws were remarkably modern insofar as allowing borrowers to take out security interests over fungible assets and future assets, while granting super-priority rights to secured creditors in bankruptcy. In practice, these non-codified credit schemes allowed firms to sell receivables and other liquid assets to factoring companies.

Figure 1 provides an overview of the security law regimes in France since 1804. Relative to

\footnotetext{
${ }^{9}$ Bypassing the formal Code was a way to facilitate their implementation on an "exceptional basis."
} 


\begin{tabular}{|c|c|c|c|c|c|c|}
\hline \multirow{2}{*}{$\begin{array}{l}\text { The regime allows for } \\
\text { security interests that are ... }\end{array}$} & \multicolumn{2}{|c|}{1804 Napoleonic Code Law } & \multicolumn{2}{|c|}{ 1970's/80's Non-Codified Laws } & \multicolumn{2}{|c|}{2006 Security Law } \\
\hline & Liquid Assets & Hard Assets & Liquid Assets & Hard Assets & Liquid Assets & Hard Assets \\
\hline ... non-possessory & NO & $\mathrm{NO}^{*}$ & YES & NO & YES & YES \\
\hline ... rechargeable & NO & $\mathrm{NO}$ & YES & NO & YES & YES \\
\hline
\end{tabular}

Figure 1. Comparison of French Security Law Regimes. The table compares the old French security law introduced by the Napoleonic Civil Law Code in 1804, the non-codified laws enacted in the late 1970's and early 1980's, and the new security law introduced by Ordonnance 2006-346 in 2006.

the Napoleonic Code, the non-codified laws of the 1970's and 1980's enhanced the pledgeability of liquid assets by allowing firms to create security interests over accounts receivables and other cash-like assets. The 2006 reform, subsequently, enhanced the pledgeability of hard assets. It did so by allowing for the creation of non-possessory security interests over hard movable assets, such as equipment and machinery, and by allowing for rechargeable security interests over hard immovable assets, such as land and buildings.

We use the above wrinkles in the French security system to design our base firm-level identification strategy. Simply put, hard assets could not be easily pledged as collateral before the 2006 reform, while liquid assets could be easily pledged. Accordingly, the 2006 reform is expected to have significantly affected the credit capacity of those firms whose pre-reform operations employed more fixed assets relative to firms operating more liquid assets. As we explain in detail below, our testing strategy will be based on a combination of matching and differences-estimation tests in which we look at the impact of Ordonnance 2006-346 on firms of different (pre-reform) asset mix composition, contrasting high- and low-fixed assets usage firms. Additional contrasts are introduced as the analysis considers progressively more granular questions regarding the impact of the 2006 collateral reform in France. ${ }^{10}$

\footnotetext{
${ }^{10} \mathrm{We}$ also exploit the observation that firms needed the services of factoring companies to pledge liquid
} 


\section{Data and Methodology}

\section{A. Data}

Our basic firm-level financial data and geographic information come from Bureau van Dijk's AMADEUS database, which covers the universe of firms from 35 European countries. Each release of the database contains only the most recent eight years of financial data per firm and excludes firms that became inactive more than four years ago. To avoid selection biases, we retrieve all data from each April release of the database between 2001 and 2011. We pool these data and delete duplicates. We collect data on French firms as well as on firms from other European Napoleonic-Code countries (Belgium, Italy, Portugal, and Spain). We exclude firms from the financial, services, utilities, and public administration sectors. Our base sample comprises private French firms with sales above five million euro, total assets above five million euro, and at least ten employees (which is close to the EU's definition of "all firms except micro firms"). The sample contains 46,433 unique firms over the 2001 to 2009 period.

Our dedicated start-up analysis uses a separate database that includes 35,660 unique French firms from AMADEUS over the same sample period. ${ }^{11}$ We also gather information on business assets. Notably, the operations of factoring companies in France were geographically fragmented, concentrated in a small set of departments containing large cities. This condition limited the geography of non-codified credit contracting since factors had a hard time obtaining accurate, timely information about firms located in the countryside (e.g., information about a firm's current accounts receivables is critical for factoring). Based on this additional wrinkle, we use firms' geographic proximity to factoring companies as an added condition modulating the effect of the 2006 reform. The results from this triple-differences test strategy are reported in Table IA.II in the Internet Appendix.

${ }^{11} \mathrm{~A}$ firm is identified as start-up if its year of incorporation corresponds to the year when the firm first appears in the database and if the firm is not the result of a merger. AMADEUS further requires that the new 
formation from France's National Institute of Statistics and Economic Studies (INSEE). Using this Census-type data source, we collect department-level statistics on start-ups. ${ }^{12}$ The relevant business start-up series come from the National Enterprise and Establishment Register Database (SIRENE). Any company, natural person, or legal entity is registered in that database when they first declare the starting of a business enterprise. The concept of start-ups used by INSEE is based on guidelines provided by the statistical office of the European Union (EUROSTAT).

Finally, we collect department-level data on employment from EUROSTAT. We use the United Nations' General Industrial Statistics (UNIDO) database (INDSTAT-4) to obtain data on capital formation and value added for four-digit ISIC industries in France.

\section{B. Variable Construction}

\section{B.1. Firm-Level Variables}

We use a firm's fixed assets intensity in the pre-reform year, 2005, to determine its exposure to the collateral regime ("treatment status"). FixedAssets is fixed assets (mnemonic: fias) divided by total assets (toas). To study the reform's credit-taking effects, we look at total, long-term, and short-term leverage ratios. TotalLeverage is short-term debt (loan) plus long-term debt (ltdb) divided by total assets. ShortTermLeverage (LongTermLeverage) is short-term (long-term) debt divided by total assets. We further define two dummy variables, DummyNoShortTermDebt and DummyNoLongTermDebt, equal to one if the corresponding term-debt variable is zero, and zero otherwise. To study firm-level real-side effects, we consider entity must have some financial data to enter the database.

${ }^{12}$ More information can be found at https://www.insee.fr/en/statistiques/series/102722714. 
firms' investment, employment, sales, profitability, and profit volatility. Investment is the sum of the annual change in fixed capital plus the change in inventories (stock), scaled by total assets. Employees is the log number of employees (emp). Sales is the log of sales (sale). Profitability is earnings before interest and taxes (ebta) divided by total assets. ProfitVolatility is the standard deviation of Profitability over the previous four years.

To study whether the reform led to "credit democratization," we look at subsamples of firms defined according to pre-reform asset size, number of employees, age, and financial constraints. Size is the log of total assets in 2005. Employees is defined as above. CompanyAge is the log difference between 2005 and the year of incorporation. Financial constraints are measured according to the methodology of Ferrando et al. (2015), who create an index of financial constraints based on the ECB/EC SAFE survey. For France, the index is defined as follows:

$$
\begin{aligned}
\text { SAFEIndex }_{i, t}= & \alpha_{s}+0.079 \times \text { FinancialLeverage }_{i t}+0.225 \times \text { CoverageRatio }_{i t} \\
& -0.971 \times \text { ProfitMargin }_{i t}-0.182 \times \text { Tangibility }_{i t}-2.085 \times \text { Cash }_{i t} \\
& -0.134 \times \text { Assets }_{i t},
\end{aligned}
$$

where FinancialLeverage is current liabilities (culi) plus long-term debt divided by total assets, CoverageRatio is interest expenses (inte) scaled by earnings before interest and taxes, ProfitMargin is profit after taxes (plat) divided by total assets, Tangibility is tangible fixed assets (tfas) divided by total assets, Cash is cash (cash) dividend by total assets, and Assets is the log of one plus total assets, all averaged over the pre-reform period. $\alpha_{s}$ is a sector-fixed 
effect. ${ }^{13}$ We classify as severely financially constrained (unconstrained) those firms within the top (bottom) decile of the French SAFE index distribution. ${ }^{14}$

In the start-up analysis, we further study a firm's distance to the closest of the five largest French cities (Paris, Lyon, Marseilles, Toulouse, and Lille; in kilometers) and its asset growth. To calculate DistanceTop5Cities, we measure the spherical distance between points $i$ (a firm's location) and $j$ (the location of the city center of one of the cities) using:

$$
\text { Distance }=\arccos (\text { deglatlon }) \times r \text {, }
$$

where deglatlon is given by: $\cos \left(L A T_{i}\right) \cos \left(L G T_{i}\right) \cos \left(L A T_{j}\right) \cos \left(L G T_{j}\right)+\sin \left(L G T_{i}\right) \sin \left(L G T_{j}\right)$ $+\cos \left(L A T_{i}\right) \sin \left(L G T_{i}\right) \cos \left(L A T_{j}\right) \sin \left(L G T_{j}\right) ; L G T_{x}\left(L A T_{x}\right)$ is the longitude (latitude) of point $x$, and $r$ is the radius of the earth (see Coval and Moskowitz (2001)). We obtain the longitudes and

\footnotetext{
${ }^{13}$ The four sectors used by the ECB are construction, trade, services, and industry.

${ }^{14}$ The ECB categorizes firms as more or less financially constrained based on qualitative information from the SAFE survey. The SAFE survey is stratified across different sectors, euro area countries, firm age, and firm ownership and categorizes firms as more or less financially constrained based on their responses to the following: (a) they report loan applications that were rejected; (b) they report loan applications for which only a limited amount of credit was granted; (c) they report loan applications that were declined by the firms because the borrowing costs were too high; and (d) they did not apply for a loan for fear of rejection ("discouraged borrowers"). Once the firms in the SAFE survey have been matched with the financial data in AMADEUS, the ECB estimates the probability that a firm is financially constrained as a function of its leverage, coverage ratio, profit margin, tangibility, cash holdings, size, and industry using a probit model. We use the estimated coefficients from the probit model to calculate the SAFE index as in Equation (1). A potential limitation of this approach is the stability of the coefficients, which means that the estimated coefficients may not apply to firms outside the estimation sample and the estimation period (see, e.g., Hoberg and Maksimovic (2015)). Results based on the SAFE Index are consistent with those based on alternative proxies of financial constraints.
} 
latitudes of the postal codes of each French firm and the city centers from geonames.org $(4,445$ postal codes). AssetGrowth is the annual log percentage change in fixed assets from the year of incorporation. Continuous variables are winsorized at the first and last percentiles each year.

\section{B.2. Industry-Level Variables}

We use four-digit ISIC sector-level data to study capital allocation efficiency. InvestmentGrowth (ValueAddedGrowth) is the natural log of the ratio of current gross fixed capital formation (value added) to its one year-lagged value. ${ }^{15}$ We also create an industry-level external financial dependence index according to Rajan and Zingales (1998). That index is calculated as the median ratio of capital expenditures net of cash flows to total capital expenditures within each three-digit SIC industry, averaged over the 1975-2005 period.

\section{Methodology}

We use mean-differences estimators to gauge the debt financing- and real-effects of the collateral reform, comparing outcome variables across high- versus low-fixed assets utilization firms over the pre- (2001 to 2005) versus post-reform (2006 to 2009) period. In particular, we estimate a series of multivariate regressions including fixed effects that can be compactly

\footnotetext{
${ }^{15}$ Both variables are GDP-deflated. Gross fixed capital formation is defined as the cost of new and used fixed assets minus the value of sales of used fixed assets, where fixed assets include land, buildings, and machinery and equipment. Value added is the value of shipments of goods (output) minus the cost of intermediate goods and required services, with adjustments made for inventories of finished goods, work-in-progress, and raw materials. Following Wurgler (2000), both variables are trimmed to correct for extreme outliers.
} 
written as:

$$
Y_{i, t}=\alpha_{i}+\alpha_{k, t}+\beta \text { Post }_{t} \times \text { Treated }_{i}+\varepsilon_{i, t},
$$

where $Y_{i, t}$ is the value of the outcome variable for firm $i$ in year $t$; with $Y_{i, t} \in\{$ LongTermLeverage, ShortTermLeverage, DummyNoLongTermDebt, DummyNoShortTermDebt, Investment, Employment, Sales, Profitability, ProfitVolatility $\}$. Post is a dummy variable that equals one for year 2006 onward, else zero. Treated is a dummy variable that equals one if firm $i$ 's 2005 fixed assets-to-total assets ratio is in the top quartile of that distribution, else zero. ${ }^{16} \alpha_{i}$ and $\alpha_{k, t}$ are firm- and interacted industry-year-fixed effects, respectively. The industry-fixed effects are based on French NAIF industry codes, equivalent to two-digit US SIC codes. We cluster standard errors at the firm level. The $\beta$ coefficient in Equation (3) can be interpreted as a regression-based difference-in-differences (DID) estimate after accounting for a host of fixed effects.

To ensure that our treated (high-fixed assets) firms and non-treated (low-fixed assets) firms are similar along important dimensions, we estimate DID regression (3) on a propensity-score (PS) matched sample. To create the PS-matched sample, we estimate a logit model of Treated on Size, CompanyAge, Employees, Profitability, and TotalLeverage, using data from the prereform year, 2005. We then match each firm from the top fixed assets quartile with a unique firm from the lower three quartiles according to the fitted value of the logit model, excluding pairs for which the distance exceeds 0.005 in the common support of the PS-matching line.

We also examine corporate default rates. Changes in default rates following a credit reform are arguably a direct measure of whether the reform may have inadvertently extended credit

\footnotetext{
${ }^{16}$ Using alternative quantiles (such as quintiles or terciles) does not alter our inferences. The choice for our identification variable is guided by the natural trade-off between bias and efficiency one faces in these cases.
} 
to risky marginal borrowers. We use a proportional Cox hazard model to fit the number of years until a firm fails. The model assumes that the hazard rate is given by:

$$
\lambda_{i, t}=\phi_{t} \exp \left(\beta \text { Treated }_{i}+\gamma \text { Post }_{t} \times \text { Treated }_{i}\right),
$$

where the hazard rate, $\lambda_{i, t}$, is the probability of firm $i$ failing at time $t$ conditional on surviving until that time. We set the failure year equal to the year in which a firm's legal status changes from an active status to one of the failure statuses in AMADEUS (if it does so). ${ }^{17} \phi_{t}$ is the baseline hazard rate common to all firms. The exponential function allows for cross-sectional variation in the hazard rate. Using a partial likelihood estimator, we obtain estimates for $\beta$ and $\gamma$ without imposing any structure on $\phi_{t}$, but accounting for right-censoring of the data. To ensure that the treated and control firms have a similar default risk before the reform, we also estimate hazard model (4) on a PS-matched sample.

\section{Financial and Real Effects of the Collateral Reform}

In this section, we analyze the effects of Ordonnance 2006-346 on the average private French firm. We first verify that our treated and matched control firms are similar across observable characteristics in the pre-reform year. We then look at the credit-contracting effects of the reform. We conclude by examining the real effects spurred by the reform.

\footnotetext{
${ }^{17}$ The failure statuses in the AMADEUS dataset are: "default of payment," "insolvency proceedings," "receivership," "bankruptcy," "dissolved (bankruptcy)," "dissolved (liquidation)," and "in liquidation."
} 


\section{A. Pre-Reform Characteristics of Treated and Control Firms}

Table I provides descriptive statistics for the treated, non-treated, and matched control firms calculated from pre-reform-year data. Panel A contrasts the mean values of the matching covariates across treated and non-treated firms, while Panel B contrasts covariates across treated and matched control firms. The table confirms that our matching procedure effectively reduces the differences between treated and control firms along critical observable dimensions. While Panel A shows that the treated firms are generally larger, younger, more profitable, and more levered than the non-treated firms, Panel B shows that the treated and matched control firms are statistically identical across the observable characteristics we consider, with all $p$-values above 0.20.

TABLE I ABOUT HERE

\section{B. Effects on Credit}

\section{B.1. Univariate Results}

Figures 2 through 4 take a first look at the debt financing effects of the collateral reform. Figure 2 depicts the mean total leverage ratios of firms in different fixed assets quartiles over our sample period. The figure suggests that the reform triggered an upward jump in debt-taking by French firms starting in 2006. The total debt-to-total assets ratio of our sample firms increased from a pre-reform average of $9 \%$ to a post-reform average of $12 \%$. Remarkably, the effect of the reform is monotonically increasing in the rate with which firms employ fixed assets in their production process: the higher the use of fixed assets, the larger the debt-taking after the reform. 


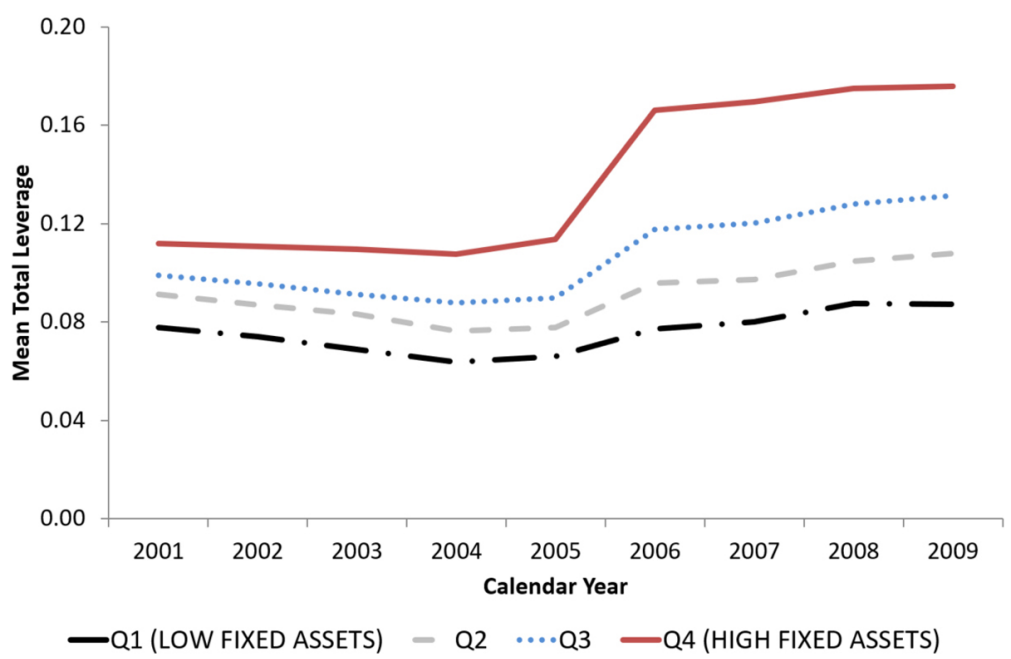

Figure 2. Evolution of Mean Total Leverage. This figure shows the evolution of the mean total leverage ratio by fixed assets quartile (Q) over the 2001 to 2009 period. Q1, Q2, Q3, and Q4 indicate the first, second, third, and fourth fixed assets quartile, respectively.
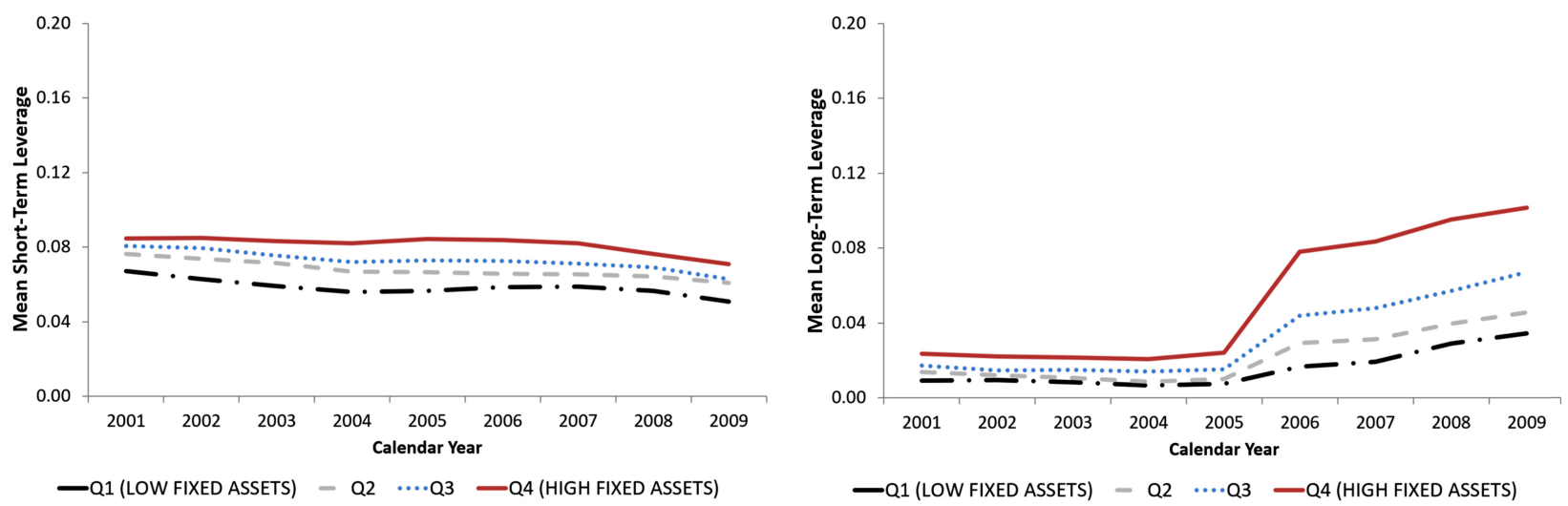

Figure 3. Evolution of Mean Short-Term vs. Mean Long-Term Leverage. This figure shows the evolution of mean short-term and mean long-term leverage by fixed assets quartile (Q) over the 2001 to 2009 period. Q1, Q2, Q3, and Q4 indicate the first, second, third, and fourth fixed assets quartile, respectively.

We next split total leverage into short-term and long-term leverage. Short-term debt in France is secured by liquid — rather than hard — assets (see Vernimmen, Quiry, and Le Fur (2015)). As such, one would not expect short-term debt to be directly affected by the reform. Accordingly, Figure 3 shows that the mean short-term leverage ratios of all fixed assets quartiles remain stable over our sample period. Long-term leverage ratios, in contrast, jump from a pre- 

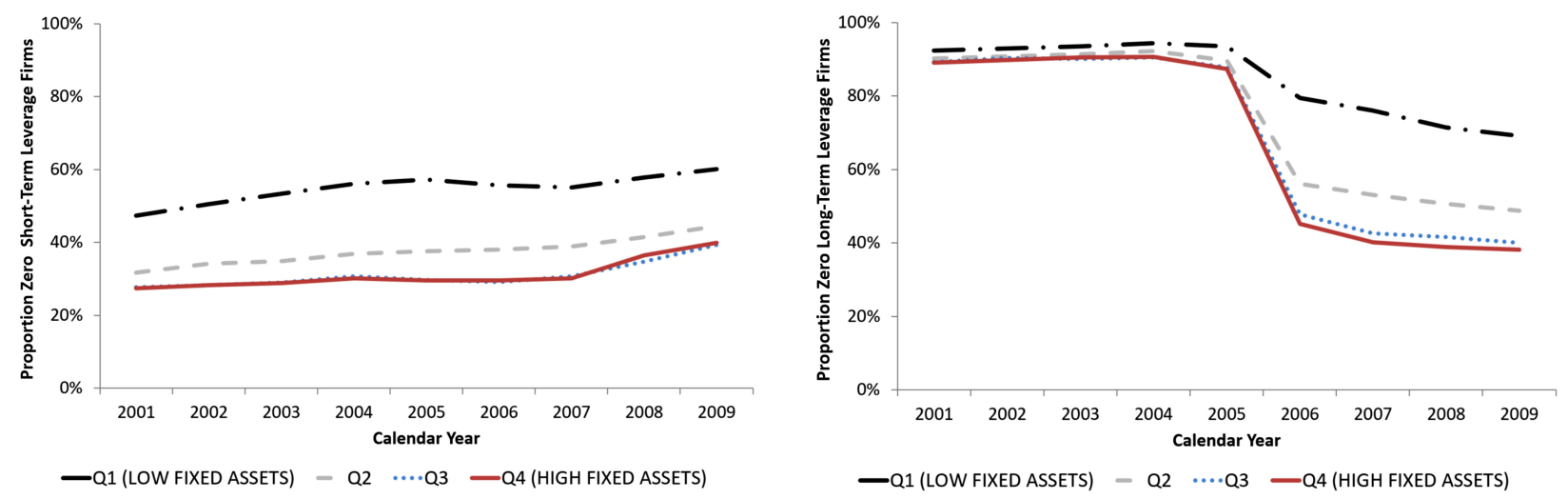

Figure 4. Evolution of the Proportions of Zero Short-Term Leverage vs. Zero-Long-Term Leverage Firms. This figure shows the evolution of the proportion of zero short-term and zero-long-term leverage firms by fixed assets quartile (Q) over the 2001 to 2009 period. Q1, Q2, Q3, and Q4 indicate the first, second, third, and fourth fixed assets quartile, respectively.

reform average of $1 \%$ to a post-reform average of $5 \%$. As in Figure 2, effect magnitudes increase monotonically over the range of fixed assets quartiles. While the long-term leverage ratio of firms in the highest fixed assets quartile rises seven percentage points from the pre-reform to the post-reform period, that of firms in the lowest quartile rises by less than two points.

We also study the reform's effect on corporate debt-taking along the extensive margin. To do so, we consider the evolution of firms with no short-term or no long-term leverage (zeroleverage firms). Figure 4 reveals that the proportion of zero short-term leverage firms across all fixed-assets quartiles remains low and stable throughout the sample period. In contrast, there are striking reductions in the proportions of zero-long-term leverage firms in the reform year. In particular, the proportion of zero-long-term leverage firms in our sample decreases from a pre-reform average of $91 \%$ to a post-reform average of $52 \%$. As in Figures 2 and 3 , the magnitude of the reductions increase monotonically over the range of the fixed-assets quartiles, with the highest fixed assets quartile firms observing the largest reduction (from $90 \%$ to $40 \%$ ). 


\section{B.2. Regression Results}

Table II presents the results of the DID regression model (3) using all our debt-taking variables as outcomes. The table points to positive and significant effects of the reform on long-term debt-taking of high-fixed assets firms. The estimate on Post $\times$ Treated in column (1) implies that high-fixed assets firms raised their long-term leverage by 2.6 percentage points more than their matched low-fixed assets firms following the reform. This is notable when compared to the average long-term leverage of high-fixed assets firms prior to the reform, which was $2.3 \%$. We further look at the effect of the 2006 reform on firms that did borrow before the reform (which we label "intensive margin") and those that did not borrow before the reform ("extensive margin"). The long-term leverage of high-fixed assets firms that borrowed long-term before the reform increased by 1.1 percentage points from before to after the reform (column (2)). While economically significant, this estimate is smaller than the total sample effect of $2.6 \%$, suggesting that leverage ratio increases were particularly significant for firms that had not borrowed prior to the reform. Indeed, the proportion of high-fixed assets zero-long-term leverage firms dropped by 10.8 percentage points more than the proportion of low-fixed assets zero-long-term leverage firms (column (3)). Notably, columns (4)-(6) suggest that the reform did not change firms' short-term debt-taking. This corroborates the internal logic of our tests in that short-term debt is not secured by hard 
assets, and as such should not respond to the reform. ${ }^{18}$

\section{TABLE II ABOUT HERE}

\section{Real Effects}

We next study how firms used the credit made available by the reform. If firms used their new financing to invest into profitable projects, the resulting changes in their performance could be seen as positive consequences of the credit reform. If, on the other hand, the impact of the reform was simply that of increasing firm indebtness, one would worry about increased corporate default rates and other negative consequences of extending credit to marginal firms.

Table III shows the results from estimating regression model (3) using investment, employment, sales, profitability, and profit volatility as outcome variables in columns (1) through (5), respectively, and from estimating hazard model (4) in column (6). High- and low-fixed assets firms are again matched based on their pre-reform characteristics. Our estimates suggest that high-fixed assets firms, which are the firms that gained most credit access from the reform, invested more and hired more workers than matched low-fixed assets firms following the reform. The estimate under column (2), for example, suggests that high-fixed assets firms observed a 3-percentage point higher employment growth than low-fixed assets firms. High-fixed assets firms

\footnotetext{
${ }^{18}$ The Internet Appendix explores alternative specifications of the models in Table II. Table IA.IV reports results from models featuring 2005 control variables interacted with year dummies; Table IA.V those from models using a more comprehensive set of Post dummies; and Table IA.VI those from models explaining net long-term leverage, defined as long-term debt minus cash scaled by total assets.
} 
also observed higher sales and profitability (see columns (3) and (4), respectively). Finally, those same firms seemingly became less risky (see column (5)), and ultimately, their default rates dropped by about 70 percent $\left(e^{-1.169}\right)$ more than those of low-fixed assets firms (see column (6)).

$\overline{\text { TABLE III ABOUT HERE }}$

Taken together, our results suggest that Ordonnance 2006-346 allowed firms operating more fixed assets to significantly raise their long-term debt-taking. Notably, the effects were more pronounced for those firms that did not borrow before the reform. Ordonnance 2006-346 had markedly less pronounced effects on the long-term debt-taking of low-fixed assets firms, and it did not affect the short-term debt financing of either high- or low-fixed assets firms. Finally, the reform allowed high-fixed assets firms to invest into additional capital and labor, with these investments likely having spurred firms' sales and profitability and decreased volatility and default risk in the years following the reform.

\section{Credit Democratization}

The term "credit democratization" has been used by policy-makers and academics in reference to the increased access to credit by individual borrowers and home buyers commonly neglected in loan markets (see, e.g., Grogan and Proscio (2000), Assunção, Benmelech, and Silva (2014), and Livshits, Mac Gee, and Tertilt (2016)). Building on previous narrative in the literature, we extend the scope of credit democratization to privately-held firms in France, which have been traditionally owned by 
individuals or families (see, e.g., Bloch and Kremp (2002) and Sraer and Thesmar (2007)). Firm location (their distance from urban/financial centers), as well as characteristics such as size and age, have been identified as likely sources of financing frictions in markets such as the US (e.g., Agarwal and Hauswald (2010) and Hadlock and Pierce (2010)) and France (Dietsch (2003) and Fonseca, Michaud, and Sopraseuth (2007)). As such, we start this section by investigating the geography of the distributional effects of Ordonnance 2006-346 on long-term debt-taking and credit access inequality across France. We next look at the differential effects of the reform on firms classified according to their asset size, number of employees, age, and a French-specific index of financing constraints.

\section{A. The Geography of the Reform's Effects}

We use spatial-point analysis to study the distributional effects of the 2006 reform (see, e.g., Kaboski and Townsend (2012)). This geography-based investigation sheds light into how policy decisions carry different implications for various regions of a country (e.g., urban versus rural areas, economically developed versus under-developed areas). We do so at a granular level, estimating the probability distribution of changes in corporate credit-contracting across different areas in France around the collateral reform. ${ }^{19}$

Spatial-point analysis allows us to determine and describe the extent to which the distribution of an event $s$ in a geographic surface $R$ exhibits regional heterogeneity ("clustering"). The function $p(s)$ defines the probability of observing the event of interest in a certain location within $R$ and can be estimated by means of non-parametric methods (e.g., kernel estimations).

\footnotetext{
${ }^{19}$ Figure IA.1 in the Internet Appendix shows further analysis on the distribution of debt-taking variables across departments before and after the reform.
} 
In our case, the surface $R$ represents the French European territory, which we divide into a set of contiguous cells ("grid"). We choose to identify and analyze the following credit events around the reform: (1) companies with large increases in their long-term leverage ratios (5\% or more); and (2) companies that did not have long-term leverage before the reform, but have positive long-term leverage every year after the reform.

The French European territory is divided in 96 fairly uniformly-sized departments. We first compute the frequency of companies satisfying condition (1) (alternatively, (2)) above in each of the 96 departments. We then compute the median value of that frequency across all departments. Next, we identify the geographic coordinates of the "centroids" of those departments with a frequency value above the median. ${ }^{20}$ Based on those coordinates, we follow Bailey and Gatrell (1995) in using kernel estimations to generate a spatially-smooth estimate of $p(s)$ over the entire grid of cells covering $R$. Each cell in the grid can comprise an arbitrarily small area. We divide the French territory in 30,000 cells and as a result each cell covers about 20 square kilometers. The estimation of the likelihood that firms in an area increase their long-term leverage according to the credit criteria we consider above allows us to build "heat maps" of the change in debt-taking across the French territory around the 2006 collateral reform. ${ }^{21}$

Figure 5 shows the heat maps one can generate with the procedure described above, with the map in Panel A focusing on increases in long-term leverage and the map in Panel B on declines in the proportion of zero-long-term leverage firms. A deeper red in either map

\footnotetext{
${ }^{20}$ Centroids are the points at the center of each department. Figure IA.2 in the Internet Appendix shows that French departments' capital cities are often located in the geographical center of their jurisdictions.

${ }^{21}$ Differently put, we estimate the probability of observing a credit event of interest across each $20 \mathrm{Km}^{2}$ of the French territory and map the results.
} 

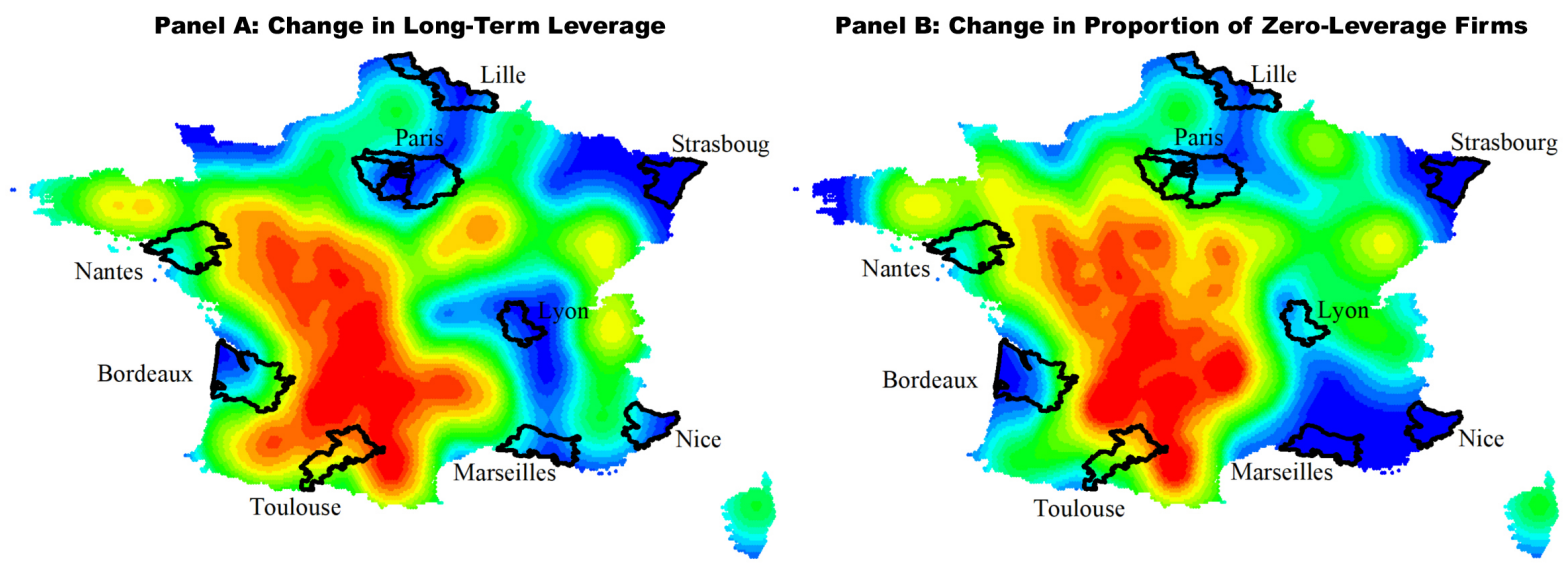

Figure 5. The Effects of the Reform on Long-Term Leverage Financing. The maps depict the probability that the proportion of firms that experienced an above five percentage points increase in long-term leverage from before to after the reform lies above the median across departments in an area (Panel A) and that the proportion of firms with no long-term leverage before the reform, but with a positive long-term leverage after the reform lies above the median across departments in an area (Panel B). The deeper red (blue) an area's color in the maps, the higher (lower) is the probability of an above median change. The black-rimmed departments contain cities with more than one million inhabitants.

indicates an area with a higher probability that the firms located in the area experienced a large increase in their long-term debt-taking from before to after the reform. For geographic context, the black-rimmed areas represent those departments containing cities with more than one million inhabitants. Both maps clearly suggest that Ordonnance 2006-346 produced significant increases in long-term debt-taking along the intensive and extensive margin across firms located in rural areas; away from the large cities and the traditional credit markets. In fact, firms located in France's South West region - an area seen as least economically developed (see, e.g., Dormard (2004)) — seem to have gained the most credit access from the reform.

We use Moran's I statistic to examine whether the visual color clusterings in our maps are 
statistically significant. ${ }^{22}$ To do so, we construct a $Z$-Score based on the mean and variance of Moran's I as:

$$
Z \text {-Score }=\frac{I-E(I)}{\sqrt{\operatorname{Var}(I)}},
$$

where $E(I)$ is the expected value of Moran's I under the null hypothesis of no spatial correlation. In other words, $E(I)$ represents the case where observations of the variable of interest (e.g., the fraction of firms with a $5 \%$ or more change in leverage) are randomly distributed across departments with no identifiable pattern. $\operatorname{Var}(I)$ is the variance of Moran's I.

Both maps in Figure 5 have positive and highly significant Moran's Z-Scores, with the left map yielding a Z-Score of 12.9 and the right map a Z-Score of 8.9. In words, the geographic distribution of high and low values of the credit events of interest is far more spatially clustered than would be expected under a random process, implying that the firms observing the largest increases in long-term debt-taking after Ordonnance 2006-346 are physically close to each other

${ }^{22}$ Moran's I statistic is calculated as:

$$
I=\frac{n \sum_{k=1}^{N} \sum_{m=1}^{N} w_{(k, m)}\left(y_{k}-\bar{y}\right)\left(y_{m}-\bar{y}\right)}{\left(\sum_{k=1}^{N} \sum_{m=1}^{N} w_{(k, m)}\right) \sum_{k=1}^{N}\left(y_{k}-\bar{y}\right)^{2}}
$$

where $n$ is the total number of observations for variable $y$. Variable $y$ represents either: (1) the fraction of firms in each department with a five or more percentage points increase in long-term leverage from the preto the post-reform period; or (2) the fraction of firms in each department with no long-term leverage before the reform, but with positive long-term leverage ratio after the reform. $k$ and $m$ are department indexes, and $w$ denotes a row-standardized binary weighted matrix, in which each element $w_{(k, m)}$ is equal to one if departments $k$ and $m$ are less than 150 miles apart from each other, else zero. We use one observation of $y$ for each department. Moran's I measures the spatial correlation between the value of each departmental observation with those of its neighbors. If the departmental observations of $y$ are independent and identically distributed (iid), then Moran's I is asymptotically normal with expected value of $\frac{-1}{n-1}$ (see Ward and Gleditsch (2008)). 
and located in specific regions of the country. To corroborate our inferences about the reform's effect on corporate credit-taking on intensive and extensive margins, we calculate the degree of overlapping across the two maps in Figure 5 using the kernel estimates of the probability of occurrence of the two credit-taking events in each single cell. ${ }^{23}$ Figure IA.3 in the Internet Appendix shows that the largest degree of overlapping between the two maps occurs precisely in their deeper red areas (84\%) and deeper blue ares (38\%). The correlation between the probability distributions underlying the two maps is equal to 0.8 , with a $p$-value of less than $0.01 \%$.

\section{B. The Reform's Effects on Credit Access Inequality}

Our prior results suggest that Ordonnance 2006-346 produced the largest increases in longterm debt-taking across rural firms that traditionally have less access to credit markets, consistent with the idea that the reform spurred a democratization of credit. To investigate this idea in more depth, we compute a Gini index of long-term debt usage to compare credit access inequality across France's regions before and after the reform. The Gini index is computed as follows:

$$
\text { GiniIndex }_{k, t}=\frac{1}{2 \mu_{k, t} N_{k, t}^{2}} \sum_{i=1}^{N_{k, t}} \sum_{j=1}^{N_{k, t}} \mid \text { LongTermDebt }_{i, t}-\text { LongTermDebt }_{j, t} \mid,
$$

where GiniIndex $x_{k, t}$ is department $k$ 's Gini index in year $t, \mu_{k, t}$ is the average long-term debt of the firms in department $k, i$ and $j$ are firm indexes, and $N_{k, t}$ is the number of firms in department $k$. We first calculate GiniIndex ${ }_{k, t}$ for each department $k$ in each year $t$. We then average the index by department over the pre- and the post-reform periods. Our calculations use a fixed

\footnotetext{
${ }^{23}$ Additional details on the construction of the overlapping measure are in the Internet Appendix.
} 
Panel A: Before Ordonnance 2006-346

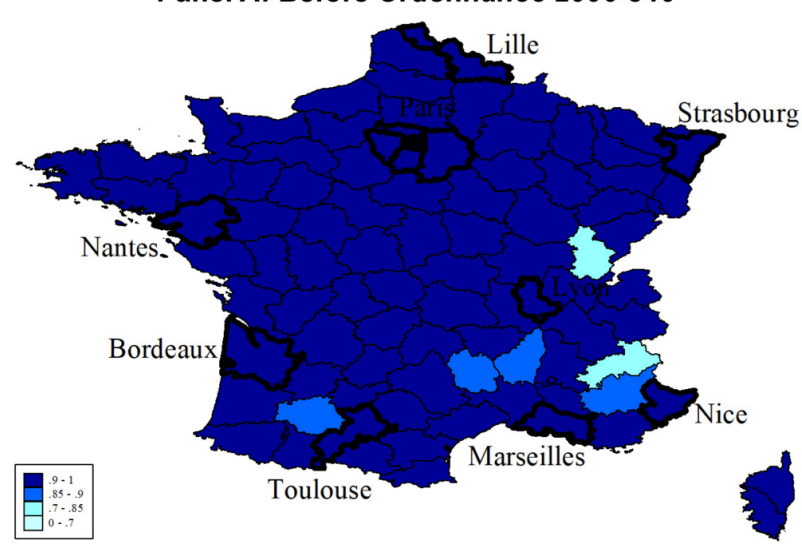

Panel B: After Ordonnance 2006-346

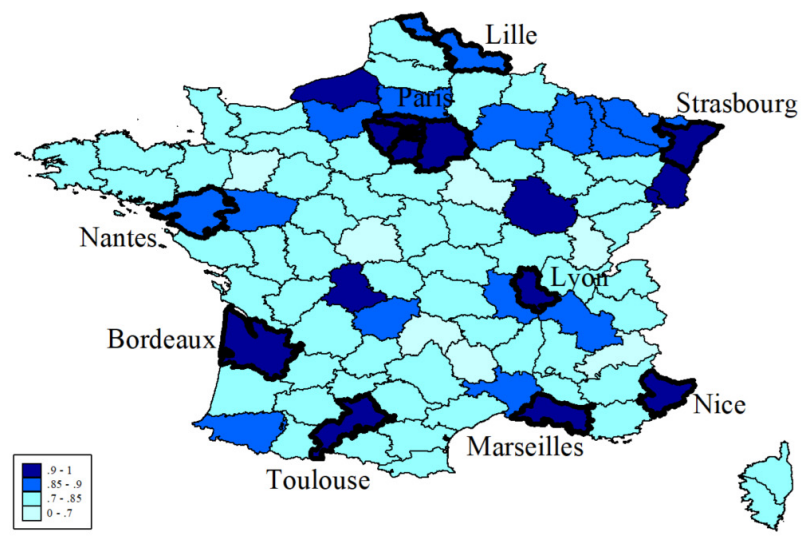

Figure 6. The Effects of the Reform on Credit Access Inequality, by Department. The maps depict each department's long-term debt Gini index for the pre-reform (Panel A) and the post-reform period (Panel B). We first calculate the Gini index by department and year, and then average by department over the pre- (2001 to 2005) or the post-reform (2006 to 2009) period. Darker (lighter) blue departments have a higher (lower) Gini index value. The black-rimmed departments are those containing cities with more than one million inhabitants.

number of observations (the 20,000 largest firms by total assets) in each year to ensure that our results are not driven by changes in sample size. The Gini index ranges from zero to one. A higher value indicates a more unequal distribution of long-term debt usage by firms in a department.

Figure 6 shows each department's Gini index, with Panel A focusing on the pre-reform period and Panel B on the post-reform period. Darker (lighter) blue departments have a relatively higher (lower) index value. Before the reform, 90 out of the 96 French departments had a Gini index above 0.90, suggesting that long-term debt was heavily concentrated in the hands of a few large firms. Following the reform, the Gini index dropped significantly to 0.82. ${ }^{24}$ Most notably, while all departments observed declines in their index values, it was

\footnotetext{
${ }^{24}$ The computed Gini index values can be interpreted as follows. Recall, before 2006 more than $90 \%$ of the firms in the country did not have any long-term debt. A Gini index of about 0.95 before 2006 is consistent with the illustrative case where $1 \%$ of the firms in the population held almost $60 \%$ of debt, $9 \%$ of the firms held the remaining 40\%, and $90 \%$ had no access to debt financing. After the reform, about $48 \%$ of the firms
} 
the rural departments that experienced the most dramatic drops. The results are notable in suggesting that the collateral reform reduced inequalities in the access to credit, with firms in the countryside experiencing the greatest gains in local credit access.

\section{The Reform's Effects on Small, Young, and Constrained Firms}

We now study whether the reform-led credit access reached firms traditionally rationed in the loan market. We first investigate the effects on firm debt taking. Table IV presents the results from the long-term leverage regression of column (1) in Table II estimated separately on subsamples of firms characterized according to their pre-reform asset size (Panel A), number of employees (Panel B), company age (Panel C), and the SAFE index-based measure of financial constraints (Panel D). The table contrasts small versus large firms, firms with few versus many employees, young versus old firms, and constrained versus unconstrained firms. ${ }^{25,26}$ The regression held some debt. A Gini index of about 0.82 after 2006 is then consistent with the case where $1 \%$ of the firms held $30 \%$ of debt, $9 \%$ held slightly more than $30 \%$, and $38 \%$ held the remaining $38 \%$.

${ }^{25}$ To define these subsamples we use the bottom/top quartile of the Size distribution; the bottom/top quartile of Employees; the below/above 30 years cut-off of CompanyAge; and the top/bottom decile of the SAFE index. In case of the company age contrasts, we omit firms with an age implying that they could have been born within our sample period. We do so to avoid that results are driven by start-ups, which we separately analyze in Section V. Also, in case of the hazard model estimations, we always contrast the bottom size-, bottom number of employees-, and top SAFE index-quartiles with all remaining quartiles since there are too few failures in the top size-, top number of employees-, and bottom SAFE index-quartiles to exclusively rely on these as contrasts.

${ }^{26} \mathrm{~A}$ confounding effect we may face in our proposed subsample contrasts comes from the fact that the control firms were not completely unaffected by the reform. To deal with this issue, we choose to contrast the treated firms from each subsample against the control firms from both subsamples. We do so by estimating regression model (3) on pooled data adding a triple interaction between Post, Treated, and a dummy variable equal to one if a firm comes from one of the treated subsamples of interest and else zero. 
estimates reveal that the collateral reform led to significantly larger increases in long-term debttaking among smaller firms, firms with fewer employees, younger firms, and more financially constrained firms. For example, the reform increased the long-term leverage of high-fixed assets firms employing less than 35 employees by an additional 1.7 percentage points compared to the long-term leverage of high-fixed assets firms with more than 165 employees (see Panel B).

\section{TABLE IV ABOUT HERE}

We also investigate whether the greater gains in long-term leverage financing observed by small, young, and financially constrained firms had a positive effect on their real business activities. Table V reports the results of the real outcomes and hazard model regressions of Table III, re-estimated across the same subsamples of firms featured in Table IV. The estimations show that small, young, and financially constrained firms experienced significantly larger increases in investment and hiring, as well as sales and profitability than large, old, and unconstrained companies (see columns (1) through (4)). Panel A, for example, suggests that small high-fixed assets firms observed a 0.9-percentage point greater investment growth and a 12.5-point greater employment growth than large high-fixed assets firms following the reform. They also experienced larger increases in their sales and profit rates. Those same firms also observed a decline in profit volatility and default rates (see columns (5) and (6)). Results in Panel D suggest that the collateral reform reduced the default rates of financially constrained high-fixed 
assets firms by an additional $25 \%$ compared to those of unconstrained high-fixed assets firms. ${ }^{27}$

TABLE V ABOUT HERE

The bulk of our evidence suggests that Ordonnance 2006-346 helped democratize credit access toward existing firms that starved for the funding of viable projects; in particular, firms located in the rural part of the country, small, young, and financially constrained firms. Those same firms became then able to increase their capital and labor investments, sales and profitability, and reduce their overall risk and default rates.

\section{Enlarged Credit Access and Entrepreneurship: How Ordonnance 2006-346 Affected Start-ups}

Our analysis so far has focused on the impact of a collateral reform on firms that were already in existence. The results showed that enlarging the contracting space with the insertion of new categories of recognizable collateral allowed firms that are traditionally constrained to obtain more credit, with measurable positive effects on activities such as investment, employment, and growth. Notably, many of those firms — often young, small, located in the countryside -

\footnotetext{
${ }^{27}$ Some estimates in Table V suggest that the operating performance of large, old, and financially unconstrained firms declined after the reform. While the "partial equilibrium effect" we describe is that the reform expanded the menu of pledgeable assets — increasing the demand for debt across the board — a likely "general equilibrium effect" is that it allowed smaller, younger, and previously constrained firms to compete more aggressively with their larger, older, and unconstrained counterparts, cutting into the operating margins of the latter set of firms.
} 
contracted debt financing for the first time. These results paint a picture consistent with the idea that Ordonnance 2006-346 helped democratize credit access toward firms that starved for the funding of viable projects. Yet, the prior analysis left out a margin that often simultaneously speaks to the issues of age, size, and financial constraints: the establishment of new firms. In this section, we study the impact of Ordonnance 2006-346 on business formation.

Using department-level data on start-ups from INSEE and employment from EUROSTAT, we start off with a spatial analysis of business formation in France around the reform, showing the relevant mapping of firm births. The heat map in Figure 7 highlights those areas in France with a high probability that the change in the ratio of start-up businesses per 1,000 workers from the pre- to the post-reform period exceeds that of the top decile across all departments, which is $4.2 .^{28}$ The deeper red (blue) an area's color in the map, the higher (lower) is the probability of observing significantly large occurrences of new business entries in a locality. The black-rimmed departments contain cities with more than one million inhabitants.

Figure 7 reveals striking similarities with Figure 5 in Section IV.A, which maps increases in credit access across France. These patterns are confirmed by spatial and panel data econometrics. First, the Moran's Z-Score is 2.9, pointing to a significant geographical clustering of business formation in the areas highlighted in red (significant at the $1 \%$ level). Second, the correlation between the distributions of the kernel estimates of the probability of start-up emergence event (mapped in Figure 7) and the event of long-term leverage change (mapped in Figure 5)

\footnotetext{
${ }^{28}$ We use department-level data from 2001 to 2008 since INSEE modified its coverage methods in 2009. After aggregating the monthly series of business start-ups in each year, we compute for each department each year the ratio of start-up businesses per 1,000 workers by dividing the number of start-ups by the number of employed workers (expressed in thousands).
} 


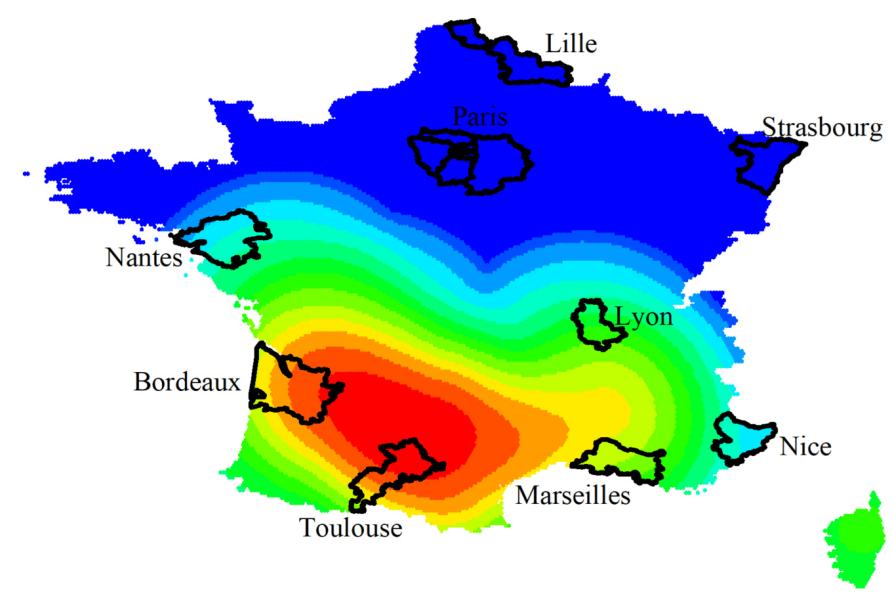

Figure 7. The Effects of the Reform on Enterprise Birth Rates. The map depicts the probability that the department median change in the ratio of start-up businesses per 1,000 workers from before to after the reform lies above the top decile across all departments. The deeper red (blue) an area's color in the map, the higher (lower) is the probability. The black-rimmed departments contain cities with more than one million inhabitants.

is 0.5 (also significant at 1\%). Panel data tests further show that the departments with red areas in common across the maps in Figures 5 and 7 ("overlapping departments") experienced the most significant positive increase in new business entries. ${ }^{29}$

We next turn our analysis to firm-level data from AMADEUS. Our raw start-up dataset contains about one hundred thousand observations across a number of industries over the 2001 to 2009 period. We are left with 35,660 observations after assigning start-ups to "treatment" and "control" groups according to whether they are in the top quartile of the distribution of fixed assets usage. In this analysis, we match treated and control start-ups at a very granular level. Specifically, we ensure that they are both in the same industry, incorporated in the same year, and located in the same French department. Table VI looks at the change in leverage ratios from before to after the reform. Panel A shows that "at-inception" leverage

\footnotetext{
${ }^{29}$ These tests are reported in Table IA.III in the Internet Appendix. Our department-level panel data analysis follows the logic of the state-level analyses contained in Kerr and Nanda (2009).
} 
ratios of start-up businesses operating more fixed assets increased significantly more around the collateral reform than the leverage ratios of industry-year-location-matched start-ups operating less fixed assets. While the leverage ratios of the treated start-ups increased by more than 13 percentage points, the leverage ratios of the control start-ups increased only by 5.5 points; an overall positive and significant difference of 7.5 points ( $t$-statistic of 11.62).

\section{TABLE VI ABOUT HERE}

The following two panels in Table VI contain an extension of our baseline test that speaks to the question of whether the reform was pronouncedly beneficial to start-ups in France. In particular, we further compare changes in start-up leverage around the reform against changes in the leverage of "matched pre-existing firms" operating in the same industry, observed in the same year, and located in the same department. With standard controls considered, this tripledifferences strategy allows us to assess whether the gains to credit access that are observed by start-ups surpassed those of their pre-existing "comparables" in the economy. Panel B shows that, while the treated start-ups observed a 7.5-percentage point increase in their leverage relative to the control start-ups from before to after the reform, the treated matched pre-existing firms observed an increase of only 4.3 points relative to the matched pre-existing control firms. Panel $\mathrm{C}$ shows that the difference in the reform-induced leverage effects between start-ups and matched pre-existing firms is 3.3 points, which is both economically and statistically significant.

We next dig deeper into post-reform outcomes for start-ups, assessing the reform's impact on metrics that speak to the issues of business formation, growth, and survival. To guide our 
work, we look at the recent literature on start-ups. Robb and Robinson (2014) describe the capital structure of newly-formed firms in the US. The authors report that those firms rely heavily on formal (outside) debt financing: business bank loans, business credit lines, and owner-backed bank loans. Critically, they find that having a capital structure that is tilted toward formal credit channels leads to a greater likelihood of business success (the outside debt ratio has a positive effect on metrics such as operating performance and size). Kerr and Nanda (2009) report a positive impact of bank branch deregulation on entrepreneurship rates in the US. Their results show that while deregulation reduced the number of small banks, it enlarged the number of branches across states, ultimately increasing access to bank credit. Interestingly, these authors report an increase in closure rates of newly-incorporated companies following deregulation: very small start-ups tended to fail within three years. In subsequent work, Kerr and Nanda (2010) show that bank deregulation also had an impact on start-up entry size.

In Table VII, we report the results from additional start-up tests adopting the matchingdifferences estimation approach used in prior sections to facilitate comparisons. Panel A suggests that, after the collateral reform, start-ups operating more fixed assets were (geographically) born farther away from France's larger cities. Specifically, the original establishments of startups operating more fixed assets observe a $12 \%$ increase in their distance to the closest of the five largest French cities (Paris, Lyon, Marseilles, Toulouse, and Lille); with that distance increasing from an average of 55 to 61 kilometers. The birthplace location of matched start-ups operating less fixed assets, in contrast, seems unaffected by the reform. To put these numbers in context, we note that ample evidence from the banking literature stresses that increases in bank-firm distances as small as one kilometer are associated with a higher likelihood of loan 
applications being rejected (see Agarwal and Hauswald (2010)). ${ }^{30}$

\section{TABLE VII ABOUT HERE}

Panel B looks at firm size at birth. The size of start-ups operating more fixed assets increased significantly with the collateral reform (from US $\$ 99$ to US $\$ 115$ thousand, on average). In contrast, the size of industry-year-location-matched start-ups operating fewer fixed assets did not materially change. Panel $\mathrm{C}$ looks at firm growth, measured by fixed asset growth over the first year following incorporation. The estimates suggest that high-fixed assets start-ups grew faster after the reform, while the growth rate of matched low-fixed assets start-ups declined. In particular, while start-ups operating more fixed assets observed an increase in their asset growth of 6.3 percentage points, start-ups operating fewer fixed assets observed a decline of 2.2 points. ${ }^{31}$

Finally, Panels D and E look at a key metric of entrepreneurial success: survival rates. Panel D reports the probability that a start-up born in the pre-reform or in the post-reform period has exited the sample at the end of that period. Analogously, Panel E reports the probability that a start-up has formally filed for bankruptcy at the end of the relevant period. The two panels do so separately

\footnotetext{
${ }^{30}$ The literature suggests that the geographic distance between a firm and a financial service provider is negatively related to credit access (see, e.g., Brevoort-Hannah (2006), Bellucci, Borisov, and Zazzaro (2013), and Lee and Brown (2017)). Looking at Italian SMEs, Bellucci, Borisov, and Zazzaro (2013) estimate that a seven-kilometer increase in the distance between a firm and a branch of its main bank increases the likelihood of significantly tighter credit terms (including credit availability).

${ }^{31}$ To avoid confounding effects arising from the global financial crisis, we run the asset growth tests in Table VII on the shorter sample period from 2003 to 2007. Running these tests on our full sample from 2001 to 2009, we, however, continue to find a significantly positive DID coefficient.
} 
for high- and low-fixed assets start-ups matched on various at-inception characteristics. While the general exit (formal bankruptcy) probability of high-fixed assets start-ups declined by about 3.3 (1.0) percentage points from the pre- to the post-reform period, the general exit (formal bankruptcy) probability of their matched low-fixed assets start-ups increased by about $2.6(0.8)$ points. The relevant difference-tests statistics are significant, but the economics of the results we show are particularly interesting in pointing out that while the levels of general exit and bankruptcy rates were indistinguishable across high- and low-fixed assets start-ups before the reform, they became markedly lower for high-fixed assets start-ups after Ordonnance 2006-346. ${ }^{32}$

The evidence of this section is novel in showing that a reform that allows parties to contract on a larger collateral menu may have important implications for business formation, growth, and survival. Notably, it suggests that the democratization of the collateral regime may lead not only to an increase in the entry of business ventures in the economy, but also to an increase in entry of what appear to be "better" entrepreneurs - entrepreneurs that are better able to grow their nascent businesses and survive more. Coming from a different perspective and setting, our results echo Robb and Robinson's (2014, p. 153) argument that: "The reliance on external debt underscores the importance of credit markets for the success of nascent business activity." Allowing start-ups to tap external debt markets appears to be an important feature of credit reforms that ultimately aim at boosting business formation and growth.

\footnotetext{
${ }^{32}$ Given the sophisticated matching used in the survival analysis in Table VII, and the fact that failure is a low probability event (e.g., less than $2 \%$ of start-ups file for bankruptcy in each year), we define treated firms as firms with an above-median fixed assets ratio in that analysis, so as to not lose too many observations.
} 


\section{Capital Allocation Efficiency}

Our evidence suggests that Ordonnance 2006-346 made creditors more willing to lend to small, young, and rural firms, usually disadvantaged in credit markets. A broader question is whether the reform led to a more efficient allocation of capital in the French economy. We use two approaches to tackle this issue.

First, we follow Wurgler's (2000) argument that an efficient capital allocation process implies that corporate investment increases in sectors with better growth opportunities and decreases in sectors with poorer opportunities. Using industry value added as proxy for growth opportunities, we estimate the elasticity of value added to investment as a way to gauge capital allocation efficiency. In our base test, we study how the overall sensitivity changes from the preto the post-reform period. We do this running the following regression on industry-level data:

$$
\text { InvestmentGrowth }_{s, t}=\alpha+\beta \text { ValueAddedGrowt } h_{s, t}+\varepsilon_{s, t},
$$

where InvestmentGrowth Ist $_{\text {is }}$ the percentage change in industry s's gross fixed capital formation from year $t-1$ to year $t$, and ValueAddedGrowt $h_{s, t}$ is the percentage change in value added over the same period. We next study whether the reform had a differential effect on the elasticity of value added to investment across industries treated by the reform (industries with high-fixed assets utilization) and those not treated by the reform (industries with low-fixed assets utilization). To do so, we run the following regression:

$$
\begin{aligned}
\text { InvestmentGrowt }_{s, t}= & \alpha+\beta \text { ValueAddedGrowt } h_{s, t}+\gamma \text { Treated }_{s} \\
& +\delta \text { ValueAddedGrowt }_{s, t} \times \text { Treated }_{s}+\varepsilon_{s, t},
\end{aligned}
$$


where Treated $_{s}$ is a dummy variable equal to one if industry s's 2005 fixed-assets ratio is in the top quartile of the fixed-assets ratio distribution of all industries, else zero.

Table VIII suggests that the sensitivity of investment to value added in France jumps from 0.48 before the reform (column (1)) to 0.85 after the reform (column (2)), with the difference, 0.36, being highly significant. More interestingly, results in columns (3) and (4) suggest that the increase in the sensitivity is almost exclusively driven by the reform-treated industries. We build on Wurgler (2000) to provide economic intuition for our estimates. Consider a shock causing value added growth to increase by $10 \%$ (e.g., a technology shock that improves the production process in an industry). Column (3) suggests that, before the reform, investment would increase by roughly $4.5 \%$ in response to the shock in industries treated by the reform and by about $5 \%$ in industries not treated by the reform. The difference between these two effects is not significant. The estimates in column (4), in contrast, suggest that, after the reform, investment in the treated industries would increase by about $15.5 \%$ (a 3-fold increase), but only by $6 \%$ in the non-treated industries. The difference in the elasticity of value added to investment across the treated and non-treated industries becomes significant in both economic and statistical terms.

$\overline{\text { TABLE VIII ABOUT HERE }}$

Our second proxy for capital allocation efficiency is the external financial dependence measure of Rajan and Zingales (1998). This measure captures an industry's technology-driven demand for external financing. In an efficient economic system, capital should be directed toward those sectors that need more external funding. If the reform relaxed credit constraints, 
one should observe significantly larger increases in borrowing among firms operating in sectors highly dependent on external financing. To test this hypothesis, we split our sample into two groups, one including sectors with a high dependence on external financing (proxy value above median) and one including sectors with a low dependence (below median). Next, we split the firms in the subsamples into "treated" and "control" firms, where treatment status is assigned to firms with a fixed assets-to-total assets ratio within the top quartile in 2005. Control status is assigned to propensity-score matched firms. We take one step further and re-run the same tests on subsamples of firms separated according to their asset size, number of employees, age, and financial constraints, similarly to what we do in Section IV.C.

Table IX suggests that treated firms with a high dependence on external financing observed greater reform-induced increases in their long-term leverage than other firms. In particular, Panel A reports that the increase in long-term leverage following the reform is larger for the highly dependent firms with a high-fixed assets intensity, 7.9 percentage points. In contrast, weakly dependent firms with a high-fixed assets intensity observe a lower average increase in long-term leverage of 5.1 percentage points.

\section{TABLE IX ABOUT HERE}

Notably, when we contrast the increases in long-term leverage of highly-dependent-highfixed assets firms across different subsamples, we find that they are economically larger among firms with smaller asset size, fewer workers, younger, and more financial constraints (see Panels B through I). For example, column (1) of Panel B shows that the mean long-term leverage of 
small highly-dependent-high-fixed assets firms increased after the reform by 10 percentage points, while for their large counterparts the increase was about 5.8 points (see Panel C column (1)). Similar figures are attached to the differences across samples of firms classified as financially constrained vis-à-vis firms that do not fall into that classification.

Taken together, our tests suggest that Ordonnance 2006-346 helped the French economy to move toward allocating more capital to high value added sectors as well as sectors that require more external financing. Our findings are consistent with the idea that the collateral reform produced positive welfare gains by reducing allocative credit distortions.

\section{Robustness}

In this section, we offer results of several robustness tests. Section A starts with parallel trends tests. Section B repeats our main debt financing regressions on placebo countries. Section C examines whether our finding that rural firms benefitted more from the collateral reform than urban firms is attributable to a tendency of rural firms to be smaller or to have a higher fixed-assets intensity than urban firms. In Table IA.VIII in the Internet Appendix, we further offer the results from repeating our main regressions on collapsed data and on public French firms.

\section{A. Parallel Trends}

The validity of DID tests rests on several assumptions; one of which is referred to as "parallel trends" assumption. To ensure that our tests yield valid results, it is important to

show that treated and control firms display conformable trends in outcome variables before 

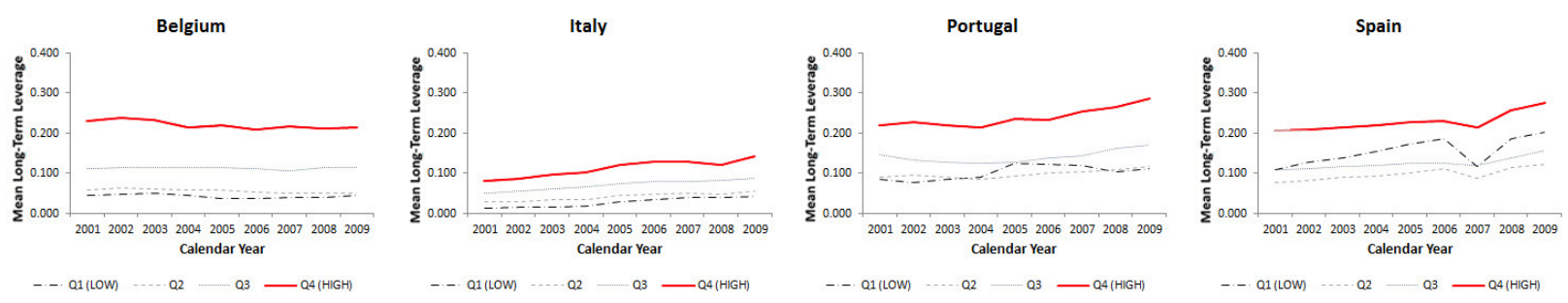

Figure 8. Evolution of Mean Long-Term Leverage in the Placebo Countries. The figure shows the evolution of mean long-term leverage for each placebo country and fixed assets quartile (Q) over the 2001 to 2009 period. The placebo countries are Belgium, Italy, Portugal, and Spain. Q1, Q2, Q3, and Q4 indicate the first, second, third, and fourth fixed assets quartile, respectively.

the reform. We have already offered some informal evidence suggesting that this is the case in Figures 2 and 3, which show that neither high- nor low-fixed assets firms observe significant trends in total, long-term, and short-term leverage over the pre-reform period. We offer more formal evidence in Table X, which shows the changes in our leverage and real effects outcome variables over the pre-reform period separately for treated and control firms. The table confirms that the changes in no single variable are significantly different across the two groups of firms. ${ }^{33}$

\section{TABLE X ABOUT HERE}

\section{B. Other Civil Law Countries}

One potential concern with our results is that West Europe-wide changes in 2006 - and not Ordonnance 2006-346 - could potentially explain the growth in long-term debt-taking by high-fixed assets firms in France. As a falsification test, we repeat our analysis using data from European Civil Law countries that had already reformed their security laws at the start

\footnotetext{
${ }^{33}$ In Table IA.VII in the Internet Appendix, we demonstrate that the size-, number of employees-, company age-, and financial constraints-subsamples used in our analysis also do not violate the parallel trends assumption.
} 
of our sample period: Belgium (a neighbor with close economic ties), Italy, Portugal, and Spain. Figure 8 offers graphical evidence that neither of those countries displayed debt-taking behaviors similar to those found in France around 2006. Regression-based evidence leading us to draw the same conclusion is offered in Table IA.IX in the Internet Appendix.

\section{Underlying Industry and Size Spatial Distribution}

One observation about our inferences regarding the geography of the effects of Ordonnance 2006-346 is that it could reflect the underlying distribution of industrial activity in France, or that rural areas may have a higher concentration of smaller companies. To examine these potential dynamics, we construct two heat maps, one representing the intensity of hard-assetusage across France before the reform, and the other tracing the distribution of firm size across the country in that same period. ${ }^{34}$ The new maps are contained in Figure 9 . We conjecture that if our central results were driven either by underlying industry-mix or firm-size distributions, we would expect to see these new heat maps displaying red areas concentrated in the rural parts of the country and blue areas in the main urban departments. We would also observe a

\footnotetext{
${ }^{34}$ Following Campello and Larrain (2016), we proceed as follows to identify and map heavy-asset industry intensity. First, using Compustat data over the 1985-2005 period, we compute the firm-level time-average ratio of PP\&E to total assets ("fixed-to-total asset ratio"). Next, we divide the sample into the 7 industry groups with SIC codes that have an international counterpart. They are: (1) 0100-0999 Agriculture, Forestry and Fishing; (2) 1000-1499 Mining; (3) 1500-1799 Construction; (4) 2000-3999 Manufacturing; (5) 4000-4999 Transportation and Communications; (6) 5000-5199 Wholesale Trade; and (7) 5200-5999 Retail Trade. For each industrial group, we identify the representative fixed-to-total asset ratio to be that of the median firm operating in the industry. Finally, we rank the industries based on the industry-median values of the fixed-to-total asset ratio. To map firms based on size, we define a firm as "small" if its number of employees from 2001 to 2005 is in the bottom $5 \%$ of the distribution.
} 

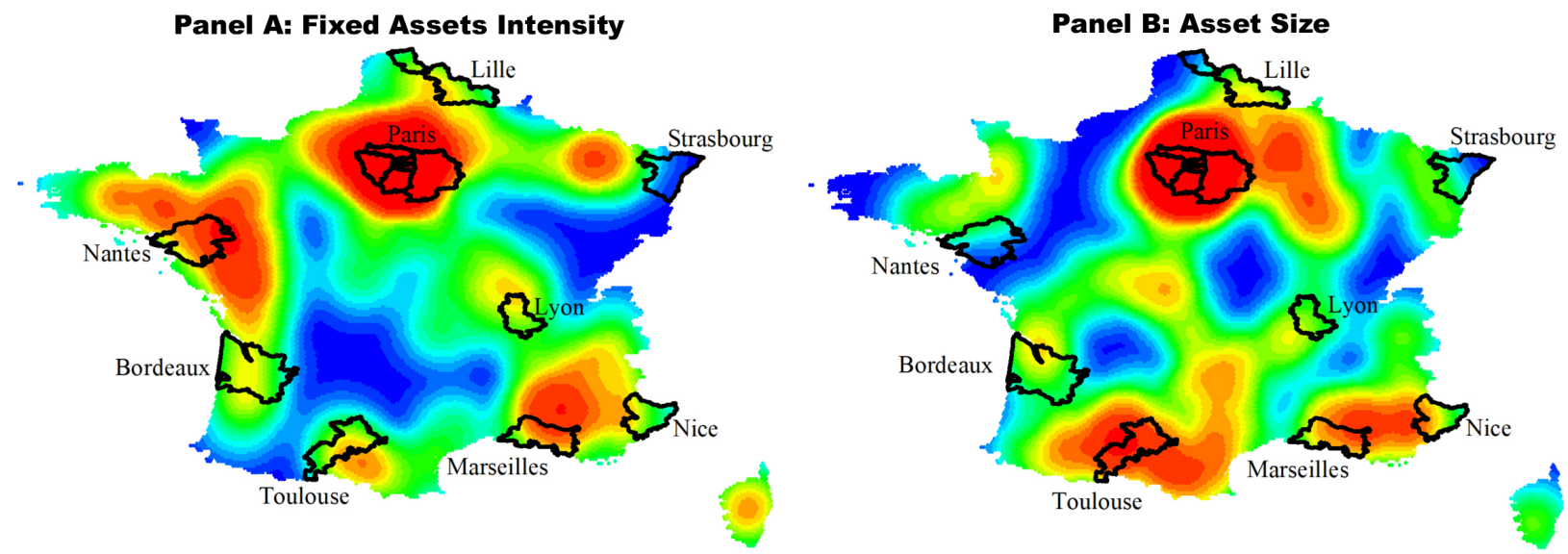

Figure 9. Pre-Reform Fixed Assets Intensity and Asset Size Distributions. The maps depict the probability that the fraction of firms operating in the three industries relying most heavily on fixed assets exceeds the median across departments (Panel A), and that the fraction of small firms exceeds the median across departments (Panel B) in 2005. The deeper red (blue) an area's color in the maps, the higher (lower) is the probability of being above the median. The black-rimmed departments contain cities with more than one million inhabitants.

high degree of color-code overlapping between these maps and the credit maps in Figure 5. We find no such patterns, nonetheless. To substantiate this inference, we conducted a series of spatial correlation analyses between the relevant sets of maps. The degree of overlapping between the map in Panel A (B) of Figure 9 and the map in Panel A of Figure 5, for example, is close to zero (zero) in the deeper red areas and $8 \%(1 \%)$ in the deeper blue areas. Indeed, the correlation between the two probability distributions is equal to $-0.4(-0.1)$, with a $p$-value of less than $1 \%$. The heat maps suggest that firms in different parts of the country may use more fixed assets in their production process, and may also be small. However, there is no evidence to suggest that firms in/close to bigger cities use less fixed assets, or are mostly large firms. 


\section{Concluding Remarks}

We examine France's Ordonnance 2006-346 to assess how reforms that ease credit access by enlarging collateral menus change the depth and demographics of corporate debt utilization. We show that the reform significantly increased the debt-taking of French firms with no access to public security markets along both the intensive and the extensive margins with positive repercussions on fixed capital investment, employment, sales growth, and profitability. We also document significant declines in profit volatility and, ultimately, a lower probability of filling for bankruptcy after the reform. More importantly, we find that the reform-led access reached firms previously rationed in the credit market. We find that the reform benefitted particularly firms that are small, young, or are classified as financially constrained, and generally located in the rural parts of the country (far away from financial centers). We also show novel evidence that a reform that improved the efficiency of the collateral regime had important implications for business formation, growth, and survival, suggesting that the democratization of the collateral regime may lead not only to an increase in the entry of business ventures in the economy, but also to an increase in entry of promising new entrepreneurs.

The derogation of the anachronic Napoleonic security code led to far reaching changes in the make up of investment and growth in the French economy. It prompted an increase in the elasticity between investment and value added, in particular in those industries mostly affected by the reform. It also allowed for more borrowing by firms operating in industries heavily reliant on external financing. All combined, our results point to a significant improvement in capital allocation efficiency in the economy. This is an important effect from a policy-making perspective 
since reforms of this nature may require fewer resources to implement and maintain than reforms that focus, for example, on law enforcement and judicial intervention. 


\section{REFERENCES}

Agarwal, Sumit, and Robert Hauswald, 2010, Distance and private information in lending, Review of Financial Studies 23, 2757-2788.

Ancel, Marie-Elodie, 2008, Recent reform in France: The renaissance of a civilian collateral regime, in Frederique Dahan, and John Simpson, eds.: Secured Transaction Reform and Access to Credit (Edward Elgar Publishing, Cheltenham).

Arena, Matteo P., and Michaël Dewally, 2012, Firm location and corporate debt, Journal of Banking \& Finance 36, 1079-1092.

Assunção, Juliano J., Efraim Benmelech, and Fernando S. S. Silva, 2014, Repossession and the democratization of credit, Review of Financial Studies 27, 2661-2689.

Bailey, Trevor C., and Anthony C. Gatrell, 1995, Interactive Spatial Data Analysis (Routledge, Essex).

Bellucci, Andrea, Alexander Borisov, and Alberto Zazzaro, 2013, Do banks price discriminate spatially? Evidence from small business lending in local credit markets, Journal of Banking \& Finance 37, 4183-4197.

Benmelech, Efraim, and Tobias J. Moskowitz, 2010, The political economy of financial regulation: Evidence from US state usury laws in the 19th century, Journal of Finance 65, 1029-1073.

Bloch, Laurence, and Elisabeth Kremp, 2002, Ownership and voting power in France, in Fabrizio Barca, and Macro Becht, eds.: The Control of Corporate Europe (Oxford University Press, New York).

Brevoort, Kenneth P., and Timothy H. Hannan, 2006, Commercial lending and distance: Evidence from Community Reinvestment Act data, Journal of Money, Credit and Banking 38, 1991-2012. 
Calomiris, Charles W., Mauricio Larrain, José Liberti, and Jason Sturgess, 2017, How collateral laws shape lending and sectoral activity, Journal of Financial Economics 123, 163-188.

Campello, Murillo, and Mauricio Larrain, 2016, Enlarging the contracting space: Collateral menus, access to credit, and economic activity, Review of Financial Studies 29, 349-383.

Castellano, Giuliano G., 2015, Reforming non-possessory secured transactions laws: A new strategy?, The Modern Law Review 78, 611-640.

Cerqueiro, Geraldo, Steven Ongena, and Kasper Roszbach, 2016, Collateralization, bank loan rates, and monitoring, Journal of Finance 71, 1295-1322.

Chatterji, Aaron K., and Robert C. Seamans, 2012, Entrepreneurial finance, credit cards, and race, Journal of Financial Economics 106, 182-195.

Coval, Joshua D., and Tobias J. Moskowitz, 2001, Home bias at home: Local equity preference in domestic portfolios, Journal of Finance 54, 2045-2073.

Davydenko, Sergei A., and Julian R. Franks, 2008, Do bankruptcy codes matter? A study of defaults in France, Germany, and the UK, Journal of Finance 63, 565-608.

DeYoung, Robert, Lawrence G. Goldberg, and Lawrence J. White, 1999, Youth, adolescence, and maturity of banks: Credit availability to small business in an era of banking consolidation, Journal of Banking \&3 Finance 23, 463-492.

Dietsch, Michel, 2003, Financing small businesses in France, European Investment Bank Papers 8, 93-119.

Djankov, Simeon, Caralee McLiesh, and Andrei Shleifer, 2007, Private credit in 129 countries, Journal of Financial Economics 84, 299-329.

Dormard, Serge, 2004, Economic development and regional disparities in France, in Helmut Karl, and Philippe Rollet, eds.: Employment and Regional Development Policy: Market Efficiency Versus Policy Intervention (Verlag der ARL - Akademie für Raumforschung und Landesplanung, Hannover). 
Ferrando, Annalisa, Matteo Iudice, Carlo Altomonte, Sven Blank, Marie-Hélène Felt, Philipp Meinen, Katja Neugebauer, and Iulia Siedschlag, 2015, Assessing the financial and financing conditions of firms in Europe: The financial module in CompNet, ECB Working Paper 1836.

Fleisig, Heywood, Mehnaz Safavian, and Nuria de la Peña, 2006, Reforming Collateral Laws to Expand Access to Finance (The World Bank, Washington).

Fonseca, Raquel, Pierre-Carl Michaud, and Thepthida Sopraseuth, 2007, Le travail indépendant passé 50 ans: Le rôle de la richesse individuelle et des coûts de création d'entreprise, Économie et Statistique 403, 63-82.

Goode, Royston M., 1974, A credit law for Europe?, International and Comparative Law Quarterly 23, 227-291.

Granja, João, Christian Leuz, and Raghuram Rajan, 2018, Going the extra mile: Distant lending and credit cycles, Working Paper, National Bureau of Economic Research.

Grogan, Paul S., and Tony Proscio, 2000, Comeback Cities: A Blueprint for Urban Neighborhood Revival (Westview Press, Boulder).

Hadlock, Charles J., and Joshua R. Pierce, 2010, New evidence on measuring financial constraints: Moving beyond the KZ Index, Review of Financial Studies 23, 1909-1940.

Haimo, Stephan H., 1983, A practical guide to secured transactions in France, Tulane Law Review 58, 1163-1205.

Hauswald, Robert, and Robert Marquez, 2006, Competition and strategic information acquisition in credit markets, Review of Financial Studies 19, 968-1000.

Herbet, Jerome, and Carole Sabbah, 2006, Will secured lending in France benefit from the recent overhaul of civil code provisions relating to security interests?, International Business Law Journal 6, 853-859. 
Hoberg, Gerard, and Vojislav Maksimovic, 2015, Redefining financial constraints: A text-based analysis, Review of Financial Studies 28, 1312-1352.

Kaboski, Joseph P., and Robert M. Townsend, 2012, The impact of credit on village economies, American Economic Journal: Applied Economics 4, 98-133.

Kerr, William R., and Ramana Nanda, 2009, Democratizing entry: Banking deregulation, financing constraints, and entrepreneurship, Journal of Financial Economics 94, 124-149.

Kerr, William R., and Ramana Nanda, 2010, Banking deregulations, financing constraints, and firm entry size, Journal of the European Economic Association 8, 582-593.

Keys, Benjamin J., Tanmoj Mukherjee, Amit Seru, and Vikrant Vig, 2010, Did securitization lead to lax screening? Evidence from subprime loans, Quarterly Journal of Economics $125,307-362$.

Kieninger, Eva-Maria, 2004, Introduction: Security rights in movable property within the common market and the approach of the study, in Eva-Maria Kieninger, ed.: Security Rights in Movable Property in European Private Law (Cambridge University Press, New York).

La Porta, Rafael, Florencio Lopez-de-Silanes, Andrei Shleifer, and Robert W. Vishny, 1998, Law and finance, Journal of Political Economy 106, 1113-1155.

Lee, Neil, and Ross Brown, 2017, Innovation, SMEs, and the liability of distance: The demand and supply of bank funding in UK peripheral regions, Journal of Economic Geography 17, 233-260.

Lilienfeld-Toal, Ulf, Dilip Mookherjee, and Sujata Visaria, 2012, The distributive impact of reforms in credit enforcement: Evidence from Indian debt recovery tribunals, Econometrica $80,497-558$.

Livshits, Igor, James C. Mac Gee, and Michèle Tertilt, 2016, The democratization of credit and the rise in consumer bankruptcies, Review of Economic Studies 83, 1673-1710. 
Lofstedt, Charles, and Andrew Baum, 1993, A comparative study of commercial leasing structures in selected European countries and in the USA, Centre for European Property Research.

Mian, Atif, and Amir Sufi, 2010, The great recession: Lessons from microeconomic data, American Economic Review: Papers 83 Proceedings 100, 51-56.

Omar, Paul J., 2007, Updating the framework for asset security in France: The reforms of 2006, Journal of Comparative Law 2, 189-209.

Omar, Paul J., 2014, A reform in search of a purpose: French insolvency law changes (again!), International Insolvency Review 23, 201-220.

Plantin, Giullaume, David Thesmar, and Jean Tirole, 2013, Reforming French bankruptcy law, Notes du Conseil D'Analyse Économique 7, 1-12.

Rajan, Raghuram G., and Luigi Zingales, 1998, Financial dependence and growth, American Economic Review 88, 559-586.

Renaudin, Muriel, 2013, The modernisation of French secured credit law: Law as a competitive tool in global markets, International Company and Commercial Law Review 24, 385-392.

Riffard, Jean-Francois, 2016, The still uncompleted evolution of the French law on secured transactions towards modernity, in Louise Gullifer, and Orkun Akseli, eds.: Secured Transactions Law Reform: Principles, Policies, and Practice (Hart Publishing, Oregon).

Robb, Alicia M., and David T. Robinson, 2014, The capital structure decisions of new firms, Review of Financial Studies 27, 153-179.

Schmalz, Martin C., David A. Sraer, and David Thesmar, 2017, Housing collateral and entrepreneurship, Journal of Finance 72, 99-132.

Sraer, David, and David Thesmar, 2007, Performance and behavior of family firms: Evidence from the French stock market, Journal of the European Economic Association 5, 709-751. 
Vernimmen, Pierre, Pascal Quiry, and Yann Le Fur, 2014, Finance d'Enterprise (Dalloz-Sirey, Paris).

Vig, Vikrant, 2013, Access to collateral and corporate debt structure: Evidence from a natural experiment, Journal of Finance 68, 881-928.

Ward, Michael D., and Kristian S. Gleditsch, 2008, Spatial Regression Models (Sage Publicatons, London).

White, Michelle J., 2007, Bankruptcy reform and credit cards, Journal of Economic Perspectives 21, 175-199.

Wurgler, Jeffrey, 2000, Financial markets and the allocation of capital, Journal of Financial Economics 58, 187-214. 


\section{Table I}

\section{Comparison of High- and Low-Fixed Assets Firms in the Pre-Reform Year}

This table shows the mean values of several firm characteristics for the full sample of treated and non-treated firms (Panel A) and a propensity score (PS) matched sample of treated and control firms (Panel B) in the pre-reform year (2005). The firm characteristics are size, company age, number of employees, profitability, and total leverage. Size is the log of total assets. Company age is the log difference between 2005 and the year of incorporation. Number of employees is the log of the number of employees. Profitability is earnings before interest and taxes scaled by assets. Total leverage is the sum of short-term and long-term debt scaled by assets. The treated firms are those with a 2005 fixed-to-total assets ratio in the top quartile of that distribution; the non-treated firms are all other firms. Each treated firm is matched with one unique control firm. The table also shows the mean difference in the firm characteristics across the treated and non-treated or matched control firms, with the $p$-value of the difference given in square brackets.

\begin{tabular}{lccccc}
\hline & Size & $\begin{array}{c}\text { Company } \\
\text { Age }\end{array}$ & $\begin{array}{c}\text { Number } \\
\text { Employees }\end{array}$ & $\begin{array}{c}\text { Prof- } \\
\text { itability }\end{array}$ & $\begin{array}{c}\text { Total } \\
\text { Leverage }\end{array}$ \\
\hline Panel A: Means for Treated and Non-Treated Firms in 2005 & & & \\
\hline Treated & 9.586 & 2.817 & 4.374 & 0.102 & 0.114 \\
Non-Treated & 9.116 & 2.866 & 3.945 & 0.095 & 0.078 \\
Difference & 0.470 & -0.049 & 0.429 & 0.007 & 0.036 \\
$p$-value & {$[0.00]$} & {$[0.00]$} & {$[0.00]$} & {$[0.00]$} & {$[0.00]$} \\
\hline Panel B: Means for Treated and PS-Matched Control Firms in 2005 & & \\
\hline Treated & 9.578 & 2.885 & 4.362 & 0.103 & 0.103 \\
Controls & 9.585 & 2.884 & 4.362 & 0.100 & 0.105 \\
Difference & -0.007 & 0.001 & 0.000 & 0.003 & -0.002 \\
$p$-value & {$[0.77]$} & {$[0.95]$} & {$[0.99]$} & {$[0.20]$} & {$[0.57]$} \\
\hline
\end{tabular}




\section{Table II}

\section{The Effect of the Collateral Reform on Leverage: Difference-in-Differences Matching Estimations}

This table shows the results from the following model estimation:

$$
Y_{i, t}=\alpha_{i}+\alpha_{k, t}+\beta \text { Post }_{t} \times \text { Treated }_{i}+\varepsilon_{i, t},
$$

where $Y$ is: the long-term leverage ratio (columns (1)-(2)), a no long-term debt dummy (column (3)), the short-term leverage ratio (columns (4)-(5)), or a no short-term debt dummy (column (6)). Post is a dummy equal to one starting from 2006 onwards, else zero. Treated is a dummy equal to one for firms with a 2005 fixed-to-total assets ratio in the top quartile of that distribution, else zero. $\alpha_{i}$ and $\alpha_{k, t}$ indicate firm-fixed and industry-year-fixed effects, respectively. The "Intensive Margin" ("Extensive Margin") regressions in columns (2) and (5) (columns (3) and (6)) exclude firms with zero (firms with positive) pre-reform debt. All regressions are run on a propensity-score-matched sample using 2005 values of size, age, number of employees, profitability, and total leverage as covariates. Each treated firm is matched with one unique control firm. $T$-statistics (in parentheses) are calculated from standard errors clustered at the firm level.

\begin{tabular}{|c|c|c|c|c|c|c|}
\hline & \multicolumn{3}{|c|}{$\begin{array}{c}\text { Long-Term Leverage } \\
\text { (Treated by the Reform) }\end{array}$} & \multicolumn{3}{|c|}{$\begin{array}{c}\text { Short-Term Leverage } \\
\text { (Not Treated by the Reform) }\end{array}$} \\
\hline & Total & $\begin{array}{l}\text { Intensive } \\
\text { Margin }\end{array}$ & $\begin{array}{l}\text { Extensive } \\
\text { Margin }\end{array}$ & Total & $\begin{array}{l}\text { Intensive } \\
\text { Margin }\end{array}$ & $\begin{array}{l}\text { Extensive } \\
\text { Margin }\end{array}$ \\
\hline & (1) & $(2)$ & $(3)$ & (4) & $(5)$ & (6) \\
\hline Post $\times$ Treated & $\begin{array}{l}0.026^{* * *} \\
(14.54)\end{array}$ & $\begin{array}{l}0.011^{* * *} \\
(2.98)\end{array}$ & $\begin{array}{l}-0.108^{* * *} \\
(-9.90)\end{array}$ & $\begin{array}{r}0.000 \\
(0.08)\end{array}$ & $\begin{array}{r}0.000 \\
(0.00)\end{array}$ & $\begin{array}{l}-0.029 \\
(-0.97)\end{array}$ \\
\hline Adj. R-squared & 0.07 & 0.02 & 0.34 & 0.01 & 0.01 & 0.04 \\
\hline Observations & 89,826 & 25,470 & 64,356 & 89,826 & 86,457 & 3,369 \\
\hline
\end{tabular}

${ }^{* * *},{ }^{* *}$, and ${ }^{*}$ indicate significance at the $99 \%, 95 \%$, and $90 \%$ confidence levels, respectively. 


\section{Table III \\ The Effect of the Collateral Reform on Firm Performance: Difference-in-Differences Matching Estimations}

The first five columns of this table show the results from the following model estimation:

$$
Y_{i, t}=\alpha_{i}+\alpha_{k, t}+\beta \text { Post }_{t} \times \text { Treated }_{i}+\varepsilon_{i, t},
$$

while the final column shows the results from the following proportional Cox hazard model estimation:

$$
\lambda_{i, t}=\phi_{t} \exp \left(\text { Breated }_{i}+\gamma \text { Post }_{t} \times \text { Treated }_{i}\right)
$$

$Y$ is: investment, employment, sales, profitability, or profit volatility. Investment is the sum of the annual change in fixed capital plus the change in inventories, scaled by total assets. Employment is the log of the number of employees. Sales is the log of sales. Profitability is earnings before interest and taxes scaled by assets. Profit volatility is the standard deviation of profitability over the most recent four fiscal years. The hazard rate $\lambda_{i, t}$ is the probability of firm $i$ failing at time $t$ conditional on surviving until then, and $\phi_{t}$ is the baseline hazard rate common to all firms. We set a firm's failure year to the calendar year in which its legal status changes from an active status to one of the following failure statuses: "default of payment," "insolvency proceedings," "receivership," "bankruptcy," "dissolved," and "in liquidation." Post is a dummy equal to one starting from 2006 onwards, else zero. Treated is a dummy equal to one for firms with a 2005 fixed-to-total assets ratio in the top quartile, else zero. $\alpha_{i}$ and $\alpha_{k, t}$ indicate firm-fixed and industry-year-fixed effects, respectively. The regressions in columns (1) to (5) are run on a propensity-score-matched sample using 2005 values of size, age, number of employees, profitability, and total leverage as covariates. The estimation in column (6) is run on a within-year-andindustry propensity-score-matched sample using pre-reform average values of profitability, total leverage, and profit volatility as covariates. Each treated firm is matched with one unique control firm. T-statistics (in parentheses) are calculated from standard errors clustered at the firm level.

\begin{tabular}{lcccccc}
\hline & $\begin{array}{c}\text { Invest- } \\
\text { ment }\end{array}$ & $\begin{array}{c}\text { Employ- } \\
\text { ment }\end{array}$ & Sales & $\begin{array}{c}\text { Prof- } \\
\text { itability }\end{array}$ & $\begin{array}{c}\text { Profit } \\
\text { Volatility }\end{array}$ & $\begin{array}{c}\text { Hazard } \\
\text { Rate }\end{array}$ \\
\hline Post $\times$ Treated & $(1)$ & $(2)$ & $(3)$ & $(4)$ & $(5)$ & $(6)$ \\
\hline Adj. R-squared & $0.005^{* * *}$ & $0.030^{* * *}$ & $0.033^{* * *}$ & $0.004^{* *}$ & $-0.003^{* * *}$ & $-1.169^{* * *}$ \\
Observations & $(3.87)$ & $(2.91)$ & $(2.68)$ & $(2.25)$ & $(-2.85)$ & $(-4.74)$ \\
\hline
\end{tabular}

${ }^{* * *},{ }^{* *}$, and ${ }^{*}$ indicate significance at the $99 \%, 95 \%$, and $90 \%$ confidence levels, respectively. 


\section{Table IV}

\section{The Effect of the Collateral Reform on Leverage: Cross-Subsample Difference-in-Differences Matching Estimations}

This table shows the results from the following model estimation:

$$
Y_{i, t}=\alpha_{i}+\alpha_{k, t}+\beta \text { Post }_{t} \times \text { Treated }_{i}+\varepsilon_{i, t},
$$

separately estimated on subsamples of firms characterized according to asset size (Panel A), number of employees (Panel B), company age (Panel C), and financial constraints (Panel D), with, however, the fixed effects restricted to be identical across the subsamples. $Y$ is the long-term leverage ratio. Post is a dummy equal to one starting from 2006 onwards, else zero. Treated is a dummy equal to one for firms with a 2005 fixed-to-total assets ratio in the top quartile of that distribution, else zero. $\alpha_{i}$ and $\alpha_{k, t}$ indicate firm-fixed and industry-year-fixed effects, respectively. The subsamples are firms with a 2005 total assets value in the bottom ("Small") or top quartile ("Large"), a pre-reform number of employees in the bottom ("Few") or top quartile ("Many"), a 2005 company age below ("Young") or above 30 years ("Old"), and a pre-reform financial constraints value above ("Constrained") or below ("Unconstrained") a critical value. We use the SAFE index to measure financial constraints. The table reports each subsample $\beta$ as well as the cross-subsample difference in $\beta$ ("Diff."). All regressions are run on a propensity-score-matched sample using 2005 values of size, age, number of employees, profitability, and total leverage as covariates. Each treated firm is matched with one unique control firm. $T$-statistics (in parentheses) are calculated from standard errors clustered at the firm level.

\begin{tabular}{lccc}
\hline Panel A: Size-Based Subsample Contrasts & & \\
\hline & Small & Large & Diff. \\
\hline Post $\times$ Treated & $(1)$ & $(2)$ & $(1)-(2)$ \\
& $0.032^{* * *}$ & $0.024^{* * *}$ & $0.008^{* *}$ \\
\hline Adj. R-squared & $(9.72)$ & $(7.59)$ & $(2.09)$ \\
Observations & 0.14 & 0.03 & \\
\hline Panel B: Number of Employees-Based Subsample Contrasts & 22,440 & \\
\hline & Few & Many & Diff. \\
\hline & $(1)$ & $(2)$ & $(1)-(2)$ \\
\hline Post $\times$ Treated & $0.032^{* * *}$ & $0.015^{* * *}$ & $0.017^{* * *}$ \\
& $(10.01)$ & $(5.10)$ & $(4.28)$ \\
\hline Adj. R-squared & 0.01 & 0.01 & \\
Observations & 22,468 & 22,438 & (continued on next page)
\end{tabular}


Table IV

The Effect of the Collateral Reform on Leverage: Cross-Subsample Difference-in-Differences Matching Estimations (cont.)

\begin{tabular}{|c|c|c|c|}
\hline \multicolumn{4}{|c|}{ Panel C: Company Age-Based Subsample Contrasts } \\
\hline & Young & Old & Diff. \\
\hline & (1) & (2) & $(1)-(2)$ \\
\hline Post $\times$ Treated & $\begin{array}{l}0.028^{* * *} \\
(11.46)\end{array}$ & $\begin{array}{l}0.020^{* * * *} \\
(7.68)\end{array}$ & $\begin{array}{l}0.008^{* *} \\
(2.46)\end{array}$ \\
\hline Adj. R-squared & 0.05 & 0.10 & \\
\hline Observations & 43,457 & 27,056 & \\
\hline \multicolumn{4}{|c|}{ Panel D: Financial Constraints-Based Subsample Contrasts } \\
\hline & Constrained & Unconstrained & Diff. \\
\hline & (1) & $(2)$ & $(1)-(2)$ \\
\hline Post $\times$ Treated & $\begin{array}{l}0.026^{* * *} \\
(5.16)\end{array}$ & $\begin{array}{l}0.015^{* * *} \\
(2.96)\end{array}$ & $\begin{array}{l}0.011^{*} \\
(1.76)\end{array}$ \\
\hline Adj. R-squared & 0.05 & 0.07 & \\
\hline Observations & 8,857 & 8,856 & \\
\hline
\end{tabular}

${ }^{* * *},{ }^{* *}$, and ${ }^{*}$ indicate significance at the $99 \%, 95 \%$, and $90 \%$ confidence levels, respectively. 
Table V

\section{The Effect of the Collateral Reform on Firm Performance: Cross-Subsample Difference-in-Differences Matching Estimations}

The first five columns of this table show the results from the following model estimation:

$$
Y_{i, t}=\alpha_{i}+\alpha_{k, t}+\beta \text { Post }_{t} \times \text { Treated }_{i}+\varepsilon_{i, t},
$$

while the final column shows the results from the hazard model estimation:

$$
\lambda_{i, t}=\phi_{t} \exp \left(\beta \text { Treated }_{i}+\gamma \text { Post }_{t} \times \text { Treated }_{i}\right),
$$

separately estimated on subsamples of firms characterized according to asset size (Panel A), number of employees (Panel B), company age (Panel C), and financial constraints (Panel D), with, however, the fixed effects restricted to be identical across the subsamples. $Y$ is: investment, employment, sales, profitability, or profit volatility. See the caption of Table III for more details about these variables, the hazard rate $\lambda_{i, t}$, and our choice of failure year. Post is a dummy equal to one starting from 2006 onwards, else zero. Treated is a dummy equal to one for firms with a 2005 fixed-to-total assets ratio in the top quartile, else zero. $\alpha_{i}$ and $\alpha_{k, t}$ indicate firm-fixed and industry-year-fixed effects, respectively. The regressions in columns (1) to (5) are run on a propensity-score-matched sample using 2005 values of size, age, number of employees, profitability, and total leverage as covariates. The estimation in column (6) is run on a within-year-and-industry propensity-score-matched sample using pre-reform average values of profitability, total leverage, and profit volatility as covariates. Each treated firm is matched with one unique control firm. The subsamples are firms with a 2005 total assets value in the bottom ("Small") or top quartile ("Large"); a pre-reform number of employees in the bottom ("Few") or top quartile ("Many"); a 2005 company age below ("Young") or above 30 years ("Old"); and a pre-reform financial constraints value above ("Constrained") or below ("Unconstrained") a critical value, where we use the SAFE index to measure financial constraints. The table reports each subsample $\beta$ as well as the cross-subsample difference in $\beta$ ("Diff."). $T$-statistics (in parentheses) are calculated from standard errors clustered at the firm level.

\begin{tabular}{lcccccc}
\hline & $\begin{array}{c}\text { Invest- } \\
\text { ment }\end{array}$ & $\begin{array}{c}\text { Employ- } \\
\text { ment }\end{array}$ & Sales & $\begin{array}{c}\text { Prof- } \\
\text { itability }\end{array}$ & $\begin{array}{c}\text { Profit } \\
\text { Volatility }\end{array}$ & $\begin{array}{c}\text { Hazard } \\
\text { Rate }\end{array}$ \\
\hline & $(1)$ & $(2)$ & $(3)$ & $(4)$ & $(5)$ & $(6)$ \\
\hline Panel A: Size-Based Subsample Contrasts & & & & \\
\hline Small & $0.010^{* * *}$ & $0.106^{* * *}$ & $0.179^{* * *}$ & $0.011^{* * *}$ & $-0.005^{* *}$ & $-1.786^{* * *}$ \\
& $(4.35)$ & $(5.09)$ & $(7.29)$ & $(3.15)$ & $(-2.44)$ & $(-3.72)$ \\
Large & 0.001 & -0.019 & $-0.069^{* * *}$ & 0.001 & $-0.003^{* *}$ & $-0.896^{* * *}$ \\
& $(0.29)$ & $(-1.00)$ & $(-3.26)$ & $(0.32)$ & $(-2.08)$ & $(-2.99)$ \\
Diff. Small-Large & $0.009^{* * *}$ & $0.125^{* * * *}$ & $0.248^{* * *}$ & $0.010^{* * *}$ & -0.002 & $-0.890^{* *}$ \\
& $(3.84)$ & $(5.07)$ & $(8.97)$ & $(2.78)$ & $(-0.92)$ & $(-2.06)$ \\
\hline
\end{tabular}


Table V

The Effect of the Collateral Reform on Firm Performance: Cross-Subsample Difference-in-Differences Matching Estimations (cont.)

\begin{tabular}{|c|c|c|c|c|c|c|}
\hline & $\begin{array}{l}\text { Invest- } \\
\text { ment }\end{array}$ & $\begin{array}{c}\text { Employ- } \\
\text { ment }\end{array}$ & Sales & $\begin{array}{l}\text { Prof- } \\
\text { itability }\end{array}$ & $\begin{array}{c}\text { Profit } \\
\text { Volatility }\end{array}$ & $\begin{array}{c}\text { Hazard } \\
\text { Rate }\end{array}$ \\
\hline & (1) & $(2)$ & (3) & (4) & $(5)$ & (6) \\
\hline \multicolumn{7}{|c|}{ Panel B: Number of Employees-Based Subsample Contrasts } \\
\hline Few & $\begin{array}{l}0.012^{* * *} \\
(5.13)\end{array}$ & $\begin{array}{l}0.237^{* * *} \\
(9.66)\end{array}$ & $\begin{array}{c}0.281^{* * *} \\
(10.53)\end{array}$ & $\begin{array}{l}0.012^{* * *} \\
(4.01)\end{array}$ & $\begin{array}{l}-0.005^{* * *} \\
(-3.29)\end{array}$ & $\begin{array}{l}-1.858^{* * *} \\
(-4.05)\end{array}$ \\
\hline Many & $\begin{array}{c}0.003 \\
(1.51)\end{array}$ & $\begin{array}{l}-0.095^{* * *} \\
(-6.08)\end{array}$ & $\begin{array}{l}-0.131^{* * *} \\
(-6.61)\end{array}$ & $\begin{array}{l}-0.005^{*} \\
(-1.69)\end{array}$ & $\begin{array}{l}-0.001 \\
(-0.98)\end{array}$ & $\begin{array}{l}-0.992^{* * *} \\
(-3.90)\end{array}$ \\
\hline Diff. Few-Many & $\begin{array}{l}0.009^{* * *} \\
(3.90)\end{array}$ & $\begin{array}{l}0.332^{* * * *} \\
(13.14)\end{array}$ & $\begin{array}{c}0.412^{* * * *} \\
(14.93)\end{array}$ & $\begin{array}{l}0.016^{* * *} \\
(5.10)\end{array}$ & $\begin{array}{l}-0.004^{* *} \\
(-2.23)\end{array}$ & $\begin{array}{l}-0.865^{* *} \\
(-2.02)\end{array}$ \\
\hline \multicolumn{7}{|c|}{ Panel C: Company Age-Based Subsample Contrasts } \\
\hline Young & $\begin{array}{l}0.004^{* * *} \\
(3.26)\end{array}$ & $\begin{array}{l}0.065^{* * *} \\
(5.26)\end{array}$ & $\begin{array}{l}0.072^{* * *} \\
(5.10)\end{array}$ & $\begin{array}{l}0.005^{* *} \\
(2.49)\end{array}$ & $\begin{array}{l}-0.005^{* * *} \\
(-4.55)\end{array}$ & $\begin{array}{l}-1.159^{* * *} \\
(-3.26)\end{array}$ \\
\hline Old & $\begin{array}{l}0.002^{*} \\
(1.69)\end{array}$ & $\begin{array}{l}-0.033^{* * *} \\
(-2.66)\end{array}$ & $\begin{array}{l}-0.044^{* * *} \\
(-3.00)\end{array}$ & $\begin{array}{r}0.001 \\
(0.60)\end{array}$ & $\begin{array}{r}0.000 \\
(-0.36)\end{array}$ & $\begin{array}{l}-0.906^{* * *} \\
(-2.62)\end{array}$ \\
\hline Diff. Young-Old & $\begin{array}{c}0.002 \\
(1.37)\end{array}$ & $\begin{array}{l}0.098^{* * *} \\
(7.04)\end{array}$ & $\begin{array}{l}0.117^{* * *} \\
(7.33)\end{array}$ & $\begin{array}{l}0.004^{*} \\
(1.74)\end{array}$ & $\begin{array}{l}-0.004^{* * *} \\
(-4.12)\end{array}$ & $\begin{array}{l}-0.253 \\
(-0.89)\end{array}$ \\
\hline \multicolumn{7}{|c|}{ Panel D: Financial Constraints-Based Subsample Contrasts } \\
\hline Constrained & $\begin{array}{l}0.009^{* *} \\
(2.37)\end{array}$ & $\begin{array}{l}0.113^{* * *} \\
(3.49)\end{array}$ & $\begin{array}{l}0.209^{* * *} \\
(5.82)\end{array}$ & $\begin{array}{l}0.013^{* * *} \\
(2.66)\end{array}$ & $\begin{array}{r}0.001 \\
(0.25)\end{array}$ & $\begin{array}{l}-1.999^{* * * *} \\
(-4.34)\end{array}$ \\
\hline Unconstrained & $\begin{array}{r}0.002 \\
(0.66)\end{array}$ & $\begin{array}{l}-0.019 \\
(-0.72)\end{array}$ & $\begin{array}{l}-0.084^{* *} \\
(-2.56)\end{array}$ & $\begin{array}{r}0.001 \\
(0.16)\end{array}$ & $\begin{array}{l}-0.002 \\
(-0.86)\end{array}$ & $\begin{array}{l}-0.901 * * * \\
(-3.54)\end{array}$ \\
\hline $\begin{array}{l}\text { Diff. Constrained- } \\
\text { Unconstrained }\end{array}$ & $\begin{array}{l}0.007^{*} \\
(1.75)\end{array}$ & $\begin{array}{l}0.132^{* * *} \\
(3.58)\end{array}$ & $\begin{array}{l}0.292^{* * *} \\
(6.82)\end{array}$ & $\begin{array}{l}0.012^{* *} \\
(2.15)\end{array}$ & $\begin{array}{r}0.003 \\
(0.90)\end{array}$ & $\begin{array}{l}-1.098^{* * *} \\
(-2.55)\end{array}$ \\
\hline
\end{tabular}

\footnotetext{
${ }^{* * *},{ }^{* *}$, and ${ }^{*}$ indicate significance at the $99 \%, 95 \%$, and $90 \%$ confidence levels, respectively.
} 


\section{Table VI}

\section{The Effect of the Collateral Reform on the Leverage of Start-Ups}

This table reports the mean leverage ratios of start-ups (Panel A), matched non-start-ups (Panel B), and the differences between the mean leverage ratios of start-ups and non-start-ups (Panel C) before and after the collateral reform, using only data from the year of incorporation for the start-ups. Using either start-ups or non-start-ups, we separately consider the full sample, the treated subsample ("High-Fixed Assets Firms"), and the control subsample ("Low-Fixed Assets Firms"). The treated start-ups are those with a fixed-to-total assets ratio in the top quartile in their year of incorporation. In Panel A, we match each treated start-up with a unique start-up from the lower fixed-to-total assets quartiles from the same industry, incorporated in the same year, and located in the same French Department. Analogously, in Panel B, we match each treated (control) start-up on a unique treated (control) non-start-up from the same industry, in the same year, and located in the same French Department. The table reports means over the pre-reform period (2001-2005), the post-reform period (2006-2009), and the difference between the two periods. The final column displays the differences across treated and control firms. $T$-statistics are given in parentheses.

\begin{tabular}{|c|c|c|c|c|}
\hline & $\begin{array}{c}\text { Full } \\
\text { Sample }\end{array}$ & $\begin{array}{l}\text { High-Fixed } \\
\text { Assets Firms }\end{array}$ & $\begin{array}{l}\text { Low-Fixed } \\
\text { Assets Firms }\end{array}$ & $\begin{array}{c}\text { Diff. } \\
\text { High-Low }\end{array}$ \\
\hline & (1) & (2) & (3) & $(2)-(3)$ \\
\hline \multicolumn{5}{|l|}{ Panel A: Start-Ups } \\
\hline Pre-Reform Period (1) & 0.225 & 0.317 & 0.133 & $0.184^{* * *}$ \\
\hline Post-Reform Period (2) & 0.318 & 0.448 & 0.189 & $0.259^{* * *}$ \\
\hline Difference $(2)-(1)$ & $\begin{array}{l}0.093^{* * *} \\
(26.62)\end{array}$ & $\begin{array}{l}0.131^{* * * *} \\
(25.49)\end{array}$ & $\begin{array}{l}0.055^{* * *} \\
(13.95)\end{array}$ & $\begin{array}{l}0.075^{* * *} \\
(11.62)\end{array}$ \\
\hline \multicolumn{5}{|c|}{ Panel B: Matched Non-Start-Ups } \\
\hline Pre-Reform Period (3) & 0.115 & 0.147 & 0.082 & $0.066^{* * *}$ \\
\hline Post-Reform Period (4) & 0.147 & 0.201 & 0.092 & $0.108^{* * *}$ \\
\hline Difference (4)-(3) & $\begin{array}{l}0.032^{* * *} \\
(15.79)\end{array}$ & $\begin{array}{l}0.053^{* * *} \\
(16.78)\end{array}$ & $\begin{array}{l}0.011^{* * *} \\
(4.62)\end{array}$ & $\begin{array}{l}0.043^{* * *} \\
(11.02)\end{array}$ \\
\hline \multicolumn{5}{|c|}{ Panel C: Difference Between Start-Ups and Non-Start-Ups } \\
\hline $\begin{array}{l}\text { Difference-in-Differences } \\
{[(2)-(1)]-[(4)-(3)]}\end{array}$ & $\begin{array}{c}0.061^{* * *} \\
(15.24)\end{array}$ & $\begin{array}{l}0.077^{* * *} \\
(12.87)\end{array}$ & $\begin{array}{l}0.045^{* * *} \\
(9.99)\end{array}$ & $\begin{array}{l}0.033^{* * *} \\
(4.23)\end{array}$ \\
\hline
\end{tabular}


Table VII

\section{The Effect of the Collateral Reform on Start-Up Emergence, Growth, and Survival}

This table reports the mean distance to the closest top 5 cities (Panel A), the mean size (Panel B), the mean asset growth (Panel C), the proportion of exits (Panel D), and the proportion of bankruptcies (Panel E) for start-ups before and after the reform. Distance to the closest top 5 cities is the log distance to the closest of the five largest French cities in kilometers, and size is the $\log$ of total assets, both measured in the year of incorporation. Asset growth is log growth in fixed assets from the year of incorporation to one year later. The proportion of exits (bankruptcies) is the fraction of start-ups incorporated in the pre-reform or post-reform period that have disappeared from our sample (gone bankrupt) by the end of the corresponding period. We define a bankruptcy as a start-up whose status is equal to "default of payment," "insolvency proceedings," "receivership," "bankruptcy," "dissolved," and "in liquidation." The table considers the full sample, the treated subsample ("High-Fixed Assets Firms"), and the control subsample ("LowFixed Assets Firms") separately. The treated start-ups are those with a fixed-to-total assets ratio in the top quartile in their year of incorporation. In Panel A, we match each treated start-up with a unique start-up from the lower fixed-to-total assets quartiles by choosing a start-up from the same industry and incorporated in the same year. In Panel B, we follow a similar strategy, but match within industry, year of incorporation, and French department. In Panels C through $\mathrm{E}$, we run our tests on a propensity-score-matched sample, using size, number of employees, profitability, and total leverage in the year of incorporation as covariates and matching within year and French department. The table reports the statistics over the pre-reform period (2001-2005), the post-reform period (2006-2009), and the difference between the periods. The final column shows the differences across treated and control firms. T-statistics are given in parentheses.

\begin{tabular}{lcccc}
\hline & $\begin{array}{c}\text { Full } \\
\text { Sample }\end{array}$ & $\begin{array}{c}\text { High-Fixed } \\
\text { Assets Firms }\end{array}$ & $\begin{array}{c}\text { Low-Fixed } \\
\text { Assets Firms }\end{array}$ & $\begin{array}{c}\text { Diff. } \\
\text { High-Low }\end{array}$ \\
\hline & $(1)$ & $(2)$ & $(3)$ & $(2)-(3)$ \\
\hline Panel A: Distance to Top 5 Cities & & & & \\
\hline Pre-Reform Period (1) & 4.044 & 4.003 & 4.086 & $-0.083^{* * *}$ \\
Post-Reform Period (2) & 4.085 & 4.098 & 4.071 & 0.026 \\
\hline Difference (2)-(1) & $0.041^{* *}$ & $0.095^{* * *}$ & -0.015 & $0.109^{* * *}$ \\
& $(2.48)$ & $(4.01)$ & $(-0.55)$ & $(3.24)$ \\
\hline Panel B: Size & & & & $0.702^{* * *}$ \\
\hline Pre-Reform Period (1) & 4.601 & 4.952 & 4.250 & $0.946^{* * *}$ \\
Post-Reform Period (2) & 4.744 & 5.217 & 4.271 & $0.244^{* * *}$ \\
\hline Difference (2)-(1) & $0.143^{* * *}$ & $0.265^{* * *}$ & 0.021 & $(1.00)$ \\
& $(8.84)$ & $(12.07)$ & (continued on next page)
\end{tabular}


Table VII

The Effect of the Collateral Reform on Start-Up Emergence, Growth, and Survival (cont.)

\begin{tabular}{lcccc}
\hline & $\begin{array}{c}\text { Full } \\
\text { Sample }\end{array}$ & $\begin{array}{c}\text { High-Fixed } \\
\text { Assets Firms }\end{array}$ & $\begin{array}{c}\text { Low-Fixed } \\
\text { Assets Firms }\end{array}$ & $\begin{array}{c}\text { Diff. } \\
\text { High-Low }\end{array}$ \\
\hline Panel C: Asset Growth & $(1)$ & $(2)$ & $(3)$ & $(2)-(3)$ \\
\hline Pre-Reform Period (1) & 0.118 & 0.033 & 0.208 & $-0.175^{* * *}$ \\
Post-Reform Period (2) & 0.139 & 0.096 & 0.187 & $-0.091^{* * *}$ \\
\hline Difference (2)-(1) & 0.021 & $0.063^{* * *}$ & -0.022 & $0.085^{* * *}$ \\
& $(1.46)$ & $(5.00)$ & $(-0.82)$ & $(2.89)$ \\
\hline Panel D: General Exits & & & & \\
\hline Pre-Reform Period (1) & 0.310 & 0.309 & 0.312 & -0.003 \\
Post-Reform Period (2) & 0.307 & 0.276 & 0.338 & $-0.062^{* * *}$ \\
\hline Difference (2)-(1) & -0.004 & $-0.033^{* * *}$ & $0.026^{* *}$ & $-0.059^{* * *}$ \\
& $(-0.46)$ & $(-2.85)$ & $(2.13)$ & $(-3.52)$ \\
\hline Panel E: Bankruptcies & \multicolumn{5}{c}{} & \\
\hline Pre-Reform Period (1) & 0.027 & 0.023 & 0.031 & $-0.008^{*}$ \\
Post-Reform Period (2) & 0.026 & 0.013 & 0.039 & $-0.026^{* * *}$ \\
\hline Difference (2)-(1) & -0.001 & $-0.010^{* * *}$ & $0.008^{*}$ & $-0.018^{* * *}$ \\
& $(-0.28)$ & $(-2.84)$ & $(1.73)$ & $(-3.07)$ \\
\hline
\end{tabular}

${ }^{* * *},{ }^{* *}$, and ${ }^{*}$ indicate significance at the $99 \%, 95 \%$, and $90 \%$ confidence levels, respectively. 
Table VIII

\section{Cross-Industry Investment Allocation Efficiency Tests}

Following Wurgler (2000), the first three columns of this table report the results from the panel-data regression:

$$
\text { InvestmentGrowt }_{s, t}=\alpha+\beta \text { ValueAddedGrowt } h_{s, t}+\varepsilon_{s, t},
$$

while the final three columns report the results from the regression:

$$
\begin{aligned}
\text { InvestmentGrowth }_{s, t} & =\alpha+\beta \text { ValueAddedGrowt } \\
s, t & +\gamma \text { Treated }_{s} \\
& +\delta \text { ValueAddedGrowt }_{s, t} \times \text { Treated }_{s}+\varepsilon_{s, t}
\end{aligned}
$$

where InvestmentGrowth is the percentage change in gross fixed capital formation in industry $s$ from year $t-1$ to year $t$. ValueAddedGrowth is the percentage change in value-added in industry $s$ from year $t-1$ to year $t$. Treated is a dummy equal to one if the sector-level fixed-assets ratio in 2005 is in the top quartile of the fixed-assets ratio distribution of all ISIC industries, else zero. We estimate the regressions separately using pre- and post-reform data. The table also reports the differences in estimates across the pre- and post-reform periods (Diff.). $T$-statistics (in parentheses) are calculated from robust standard errors.

\begin{tabular}{lcccccc}
\hline & \multicolumn{5}{c}{ Sample Period } \\
\cline { 2 - 7 } & $\begin{array}{c}\text { Pre- } \\
\text { Reform }\end{array}$ & $\begin{array}{c}\text { Post- } \\
\text { Reform }\end{array}$ & $\begin{array}{c}\text { Diff. } \\
\text { Reform }\end{array}$ & $\begin{array}{c}\text { Post- } \\
\text { Reform }\end{array}$ & Diff. \\
\hline & $(1)$ & $(2)$ & $(2)-(1)$ & $(3)$ & $(4)$ & $(4)-(3)$ \\
\hline ValueAddedGrowth & $0.481^{* * *}$ & $0.845^{* * *}$ & $0.364^{* *}$ & $0.509^{* * *}$ & $0.598^{* * *}$ & 0.088 \\
& $(4.87)$ & $(6.20)$ & $(2.16)$ & $(3.59)$ & $(2.26)$ & $(0.30)$ \\
Treated & & & & -0.012 & -0.055 & -0.043 \\
& & & & $(-0.47)$ & $(-1.7)$ & $(-1.05)$ \\
ValueAddedGrowth $\times$ & & & & -0.057 & $0.964^{* *}$ & $1.020^{* * *}$ \\
Treated & & & & $(-0.21)$ & $(2.94)$ & $(2.42)$ \\
\hline Adj. R-Squared & 0.06 & 0.16 & & 0.07 & 0.17 & \\
Observations & 517 & 217 & & 349 & 144 & \\
\hline
\end{tabular}

${ }^{* * *},{ }^{* *}$, and ${ }^{*}$ indicate significance at the $99 \%, 95 \%$, and $90 \%$ confidence levels, respectively. 


\section{Table IX}

\section{The Effect of the Collateral Reform on the Leverage of Firms with High and Low External Financial Dependence}

This table shows the mean long-term leverage ratio for firms with high or low external financial dependence. Firms are further classified based on whether they have a high- ("treated") or low-fixed assets intensity ("controls"). The tests are run on all firms (Panel A); firms with a 2005 total assets value in the bottom ("Small;" Panel B) or top quartile ("Large;" Panel C); firms with a pre-reform number of employees in the bottom ("Few;" Panel D) or top quartile ("Many;" Panel E); a 2005 company age below ("Young;" Panel F) or above 30 years ("Old;" Panel G); and a pre-reform financial constraints value above ("Constrained;" Panel H) or below ("Unconstrained;" Panel I) a critical value, where we use the SAFE index to measure financial constraints. Long-term leverage is long-term debt scaled by assets. We proxy for external financial dependence by calculating the median proportion of capital expenditure not financed by cash flows from operations for US public firms over the 1975-2005 period, classifying firms in industries with an above (below) median value as high (low) dependence firms. We classify as high- (low-) fixed assets firms those with a 2005 fixed-to-total assets ratio above (below) the third quartile. The table reports averages over the pre-reform period (2001-2005), the post-reform period (2006-2009), and their differences. The final two columns show the difference in means between high and low external financial dependence firms separately for treated and control firms. All estimations are run on a propensity-score-matched sample using 2005 values of size, age, number of employees, profitability, and total leverage as covariates. Each treated firm is matched with one unique control firm.

\begin{tabular}{|c|c|c|c|c|c|c|}
\hline & \multicolumn{4}{|c|}{ External Financial Dependence } & \multirow{2}{*}{\multicolumn{2}{|c|}{$\begin{array}{c}\text { Diff. High-Low } \\
\text { Dependence }\end{array}$}} \\
\hline & \multicolumn{2}{|c|}{ High Dependence } & \multicolumn{2}{|c|}{ Low Dependence } & & \\
\hline & Treated & Controls & Treated & Controls & Treated & Controls \\
\hline & $(1)$ & $(2)$ & $(3)$ & $(4)$ & $(1)-(3)$ & $(2)-(4)$ \\
\hline \multicolumn{7}{|l|}{ Panel A: All } \\
\hline Mean 2001-2005 (1) & 0.019 & 0.014 & 0.021 & 0.015 & & \\
\hline Mean 2006-2009 (2) & 0.099 & 0.046 & 0.072 & 0.039 & & \\
\hline Diff. (2)-(1) & $0.079 * * *$ & $0.032^{* * *}$ & $0.051^{* * *}$ & $0.025^{* * *}$ & $0.028^{* * *}$ & $0.007^{* * *}$ \\
\hline \multicolumn{7}{|l|}{ Panel B: Small } \\
\hline Mean 2001-2005 (1) & 0.023 & 0.011 & 0.016 & 0.015 & & \\
\hline Mean 2006-2009 (2) & 0.124 & 0.053 & 0.074 & 0.040 & & \\
\hline Diff. $(2)-(1)$ & $0.100^{* * *}$ & $0.042^{* * *}$ & $0.059^{* * *}$ & $0.025^{* * *}$ & $0.042^{* * *}$ & $0.017^{* * *}$ \\
\hline \multicolumn{7}{|l|}{ Panel C: Large } \\
\hline Mean 2001-2005 (1) & 0.018 & 0.014 & 0.023 & 0.015 & & \\
\hline Mean 2006-2009 (2) & 0.076 & 0.040 & 0.070 & 0.036 & & \\
\hline Diff. (2)-(1) & $0.058^{* * *}$ & $\begin{array}{r}0.026^{* * * *} \\
70\end{array}$ & $0.047^{* * *}$ & $0.022^{* * *}$ & $0.010^{* * *}$ & 0.004 \\
\hline
\end{tabular}


Table IX

The Effect of the Collateral Reform on the Leverage of Firms with High and Low External Financial Dependence (cont.)

\begin{tabular}{|c|c|c|c|c|c|c|}
\hline & \multicolumn{4}{|c|}{ External Financial Dependence } & \multirow{2}{*}{\multicolumn{2}{|c|}{$\begin{array}{c}\text { Diff. High-Low } \\
\text { Dependence }\end{array}$}} \\
\hline & \multicolumn{2}{|c|}{ High Dependence } & \multicolumn{2}{|c|}{ Low Dependence } & & \\
\hline & Treated & Controls & Treated & Controls & Treated & Controls \\
\hline & (1) & $(2)$ & $(3)$ & $(4)$ & $(1)-(3)$ & $(2)-(4)$ \\
\hline \multicolumn{7}{|l|}{ Panel D: Few } \\
\hline Mean 2001-2005 (1) & 0.022 & 0.013 & 0.018 & 0.013 & & \\
\hline Mean 2006-2009 (2) & 0.110 & 0.045 & 0.073 & 0.044 & & \\
\hline Diff. $(2)-(1)$ & $0.088^{* * *}$ & $0.031^{* * *}$ & $0.056^{* * *}$ & $0.032^{* * *}$ & $0.032^{* * *}$ & 0.000 \\
\hline \multicolumn{7}{|l|}{ Panel E: Many } \\
\hline Mean 2001-2005 (1) & 0.017 & 0.014 & 0.023 & 0.016 & & \\
\hline Mean 2006-2009 (2) & 0.069 & 0.040 & 0.068 & 0.039 & & \\
\hline Diff. $(2)-(1)$ & $0.052^{* * *}$ & $0.026^{* * *}$ & $0.045^{* * *}$ & $0.023^{* * *}$ & $0.007^{* *}$ & 0.003 \\
\hline \multicolumn{7}{|l|}{ Panel F: Young } \\
\hline Mean 2001-2005 (1) & 0.017 & 0.015 & 0.022 & 0.014 & & \\
\hline Mean 2006-2009 (2) & 0.104 & 0.047 & 0.072 & 0.041 & & \\
\hline Diff. $(2)-(1)$ & $0.086^{* * *}$ & $0.032^{* * *}$ & $0.050^{* * *}$ & $0.027^{* * *}$ & $0.036^{* * *}$ & $0.005^{* *}$ \\
\hline \multicolumn{7}{|l|}{ Panel G: Old } \\
\hline Mean 2001-2005 (1) & 0.022 & 0.013 & 0.021 & 0.013 & & \\
\hline Mean 2006-2009 (2) & 0.083 & 0.043 & 0.069 & 0.045 & & \\
\hline Diff. (2)-(1) & $0.061^{* * *}$ & $0.030^{* * *}$ & $0.048^{* * *}$ & $0.032^{* * *}$ & $0.013^{* * *}$ & -0.002 \\
\hline \multicolumn{7}{|l|}{ Panel H: Constrained } \\
\hline Mean 2001-2005 (1) & 0.020 & 0.017 & 0.023 & 0.024 & & \\
\hline Mean 2006-2009 (2) & 0.120 & 0.059 & 0.089 & 0.044 & & \\
\hline Diff. (2)-(1) & $0.100^{* * *}$ & $0.042^{* * *}$ & $0.065^{* * *}$ & $0.021^{* * *}$ & $0.035^{* * *}$ & $0.021^{* * *}$ \\
\hline \multicolumn{7}{|l|}{ Panel I: Unconstrained } \\
\hline Mean 2001-2005 (1) & 0.013 & 0.014 & 0.015 & 0.008 & & \\
\hline Mean 2006-2009 (2) & 0.074 & 0.032 & 0.058 & 0.027 & & \\
\hline Diff. $(2)-(1)$ & $0.061^{* * *}$ & $0.019^{* * *}$ & $0.043^{* * *}$ & $0.019^{* * *}$ & $0.018^{* * *}$ & 0.000 \\
\hline
\end{tabular}

${ }^{* * *},{ }^{* *}$, and ${ }^{*}$ indicate statistical significance at the $99 \%, 95 \%$, and $90 \%$ confidence levels, respectively. 


\section{Table X \\ Parallel Trends Tests}

This table shows the changes in our outcome variables over the pre-reform period (2001-2005) for high- ("Treated") and low-fixed assets firms ("Control") plus the differences in the changes across the two types of firms ("Difference"). We classify as high- (low-) fixed assets firms those with a 2005 fixed-to-total assets ratio above (below) the third quartile. Long-Term Leverage is long-term debt scaled by total assets. Proportion Zero-Leverage Firms is a dummy variable equal to one for firms with no long-term leverage, else zero. Investment is the sum of the annual change in fixed capital plus the change in inventories, scaled by total assets. Employment is the log of the number of employees. Sales is the log of sales. Profitability is earnings before interest and taxes scaled by assets. Profit volatility is the standard deviation of profitability over the most recent four fiscal years. The parallel trends tests exclude firms that do not have complete data over the entire sample period. Also, they are run on a propensity-score-matched sample using 2005 values of size, age, number of employees, profitability, and total leverage as covariates. Each treated firm is matched with one unique control firm.

\begin{tabular}{lcccc}
\hline & & \multicolumn{3}{c}{ Difference } \\
& & & $\begin{array}{c}\text { Treated } \\
\text { Minus }\end{array}$ & Difference \\
& & & Control & $p$-value \\
Pre-Reform Period Change in & Treated & Control & 0.000 & {$[0.88]$} \\
Long-Term Leverage & 0.002 & 0.002 & 0.003 & {$[0.73]$} \\
Proportion Zero-Leverage Firms & 0.004 & 0.001 & 0.003 & {$[0.50]$} \\
Investment & 0.022 & 0.019 & -0.001 & {$[0.98]$} \\
Employment & -0.658 & -0.657 & -0.054 & {$[0.30]$} \\
Sales & -0.502 & -0.448 & -0.004 & {$[0.37]$} \\
Profitability & -0.101 & -0.097 & -0.001 & {$[0.70]$} \\
Profit Volatility & -0.047 & -0.047 & & \\
\hline
\end{tabular}




\title{
Internet Appendix for
}

\section{Access to Collateral and The Democratization of Credit: France's Reform of The Napoleonic Security Code}

\author{
KEVIN ARETZ, MURILLO CAMPELLO and MARIA-TERESA MARCHICA*
}

This Internet Appendix includes the results from supplementary tests, robustness tests, and placebo tests not reported in the paper. Sections IA.I and IA.II provide evidence that our results are robust to the enactment of the "2005 Safeguard Provision" (Table IA.I) and to an alternative identification strategy based on a firm's distance to factoring companies (Table IA.II), respectively. Section IA.III includes further details on the spatial-point analysis and tests on the geographic effects of Ordonnance 2006-346 on long-term leverage and the proportion of zero-long-term leverage firms variables (Figures IA.1, IA.2, and IA.3) and on new business formation (Table IA.III). Section IA.IV reports robustness tests using interacted control variables (Table IA.IV); a more comprehensive set of Post dummy variables (Table IA.V); and

${ }^{*}$ Citation format: Aretz, Kevin, Murillo Campello, and Maria-Teresa Marchica, Internet Appendix for "Access to Collateral and the Democratization of Credit: France's Reform of The Napoleonic Security Code," Journal of Finance [DOI String]. Please note: Wiley-Blackwell is not responsible for the content or functionality of any additional information provided by the authors. Any queries (other than missing material) should be directed to the authors of the article. 
the alternative dependent variables Cash and NetLongTermLeverage (Table IA.VI). Finally, Section IA.V closes with the results of parallel trends tests across subsamples of firms studied in the paper (Table IA.VII), collapsed data tests (Table IA.VIII), and placebo tests conducted on public French firms (Table IA.VIII) or other Napoleonic-Code countries (Table IA.IX).

\section{IA.I. The Effects of the 2005 Safeguard Provision}

In this section, we show that the enactment of the 2005 Safeguard Provision does not confound our conclusions about Ordonnance 2006-346. That provision gave new powers to both borrowers and creditors. On the one hand, it strengthened borrowers by allowing not-yet-insolvent firms to strategically file for bankruptcy. On the other, it awarded creditors the right to appoint a creditors' representative as well as "inspectors" to assist the creditors' representative and the judge in bankruptcy. Crucially, however, the provision applied only to firms with more than 150 employees. We use this insight to repeat our tests in Table II of the paper on a sample of firms with less than 150 employees (slightly more than $70 \%$ of the original sample). Table IA.I shows that this modification has virtually no effect on our debt-taking estimates. For example, while high-fixed assets firms with less than 150 employees raised their long-term leverage by 2.7 percentage points, the corresponding estimate for the full sample is 2.6 points. We conclude that it is unlikely that the 2005 Safeguard Provision produced any confounding effects.

TABLE IA.I ABOUT HERE 


\section{IA.II. Alternative Identification Strategy: The Geographic Distance to Factoring Companies}

In this section, we show that using an alternative identification strategy based on factoring companies yields conclusions about the debt financing effects of Ordonnance 2006-346 similar to those generated by the identification strategy used in the paper. Firms were already able to pledge their liquid assets to factoring companies before the Ordonnance (see Section I.D of the paper). Given their need for timely and accurate information about their clients, most factoring companies are, however, only willing to conduct business with firms located physically close to them. Since the operations of French factoring companies were legally constrained to identifiable geographic areas and targeted businesses locally, firms located in areas with no offerings of factoring services thus had a difficult time pledging any of their assets — either liquid or hard — before Ordonnance 2006-346. ${ }^{1}$ We use this insight to build an alternative identification strategy based on the distance of firms to factoring companies. To do so, we construct a dummy variable equal to one if a firm is registered in a geographic area (postal code) without factoring companies and zero otherwise (Treated $\left.{ }^{\text {NoFactor }}\right)$. We then estimate the following model:

$$
Y_{i, t}=\alpha_{i}+\alpha_{k, t}+\beta \text { Post }_{t} \times \text { Treated }_{i}^{\text {NoFactor }}+\varepsilon_{i, t} .
$$

Table IA.II suggests that the alternative identification strategy based on distance to factoring companies yields results similar to the strategy based on fixed assets. Panel A shows that after

\footnotetext{
${ }^{1}$ To date, over $90 \%$ of French factoring companies have only one physical branch. Only one factoring company had more than a couple dozen branches in 2006, all confined to three large cities.
} 
the reform firms located in areas without factoring companies observe an almost one percentage point greater increase in long-term debt-taking compared to firms located in areas with factoring companies (see column (1)). As in the case of the fixed-assets identification strategy, the increase in long-term debt-taking is predominantly driven by the increase in the extensive margin (see columns (2)-(3)). Further, the effects of the reform on the short-term debt-taking variables are much smaller and not significant at the $99 \%$ confidence level (see columns (4)-(6)).

\section{TABLE IA.II ABOUT HERE}

Panel B of Table IA.II reports the results of DIDID regressions combining our two identification strategies, using the distance to factoring companies to modulate the debt-taking effects of the 2006 collateral reform. In particular, we run the model:

$$
\begin{aligned}
Y_{i, t} & =\alpha_{i}+\alpha_{k, t}+\beta \text { Post }_{t} \times \text { Treated }_{i}^{\text {HighFixedAssets }} \\
& +\gamma \text { Post }_{t} \times \text { Treated }_{i}^{\text {NoFactor }} \times \text { Treated }_{i}^{\text {HighFixedAssets }}+\varepsilon_{i, t},
\end{aligned}
$$

where Treated $^{\text {HighFixedAssets }}$ is a dummy variable equal to one for firms with a 2005 fixed-to-total assets ratio in the top quartile, else zero. In areas with factoring companies, high-fixed assets firms observe a 1.9 percentage point greater increase in their long-term leverage ratios than low-fixed assets firms after the reform (see the slope coefficient of Post $\times$ Treated HighFixedAssets $^{\text {in }}$ column (1)). In contrast, in areas without factoring companies, high-fixed assets firms observe a 3.2 points greater increase in their long-term leverage than low-fixed assets firms (note the sum of 
the slope coefficients on all interaction terms), with the 1.3 point difference being significant (see column (1)). More remarkable, while the proportion of high-fixed assets firms with no long-term leverage before the reform drops by 2.8 percentage points more than the proportion of low-fixed assets firms with no long-term leverage in areas with factoring companies, that drop is 15.7 points in areas without factoring companies, with the -12.9 point difference being significant (see column (3)). We find no such effects for short-term debt usage (see columns (4)-(6)). Overall, the triple differences tests suggest that Ordonnance 2006-346 had the most positive leverage financing effects on high-fixed assets firms located far away from factoring companies.

\section{IA.III. The Geography of the Reform's Debt-Taking and New Business Formation Effects}

This section includes additional tests on the geographic effects of Ordonnance 2006-346 on both debt-taking and new business formation. In particular, Figure IA.1 depicts the distributions of departments' mean firm-level long-term leverage ratios (Panel A) and proportions of zero-long-term leverage firms (Panel B) before and after Ordonnance 2006-346. Before the reform, the vast majority of departments had a mean leverage ratio between $1 \%$ and $3 \%$ and a mean proportion of zero-leverage firms ranging between $80 \%$ and $90 \%$. These figures changed significantly with the 2006 reform. Notably, the reform shifted the bulk of the mean leverage distribution to the right (see right-side histogram in Panel A), so that after 2006 most departments registered a mean leverage ratio between $4 \%$ and $9 \%$. Likewise, the reform 

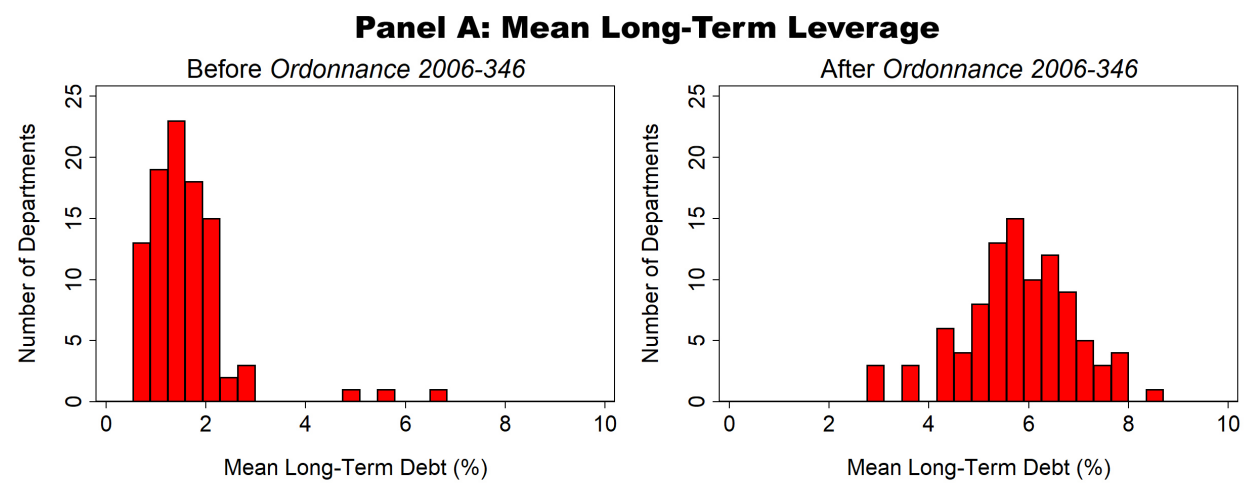

Panel B: Proportion Zero-Long-Term Leverage Firms
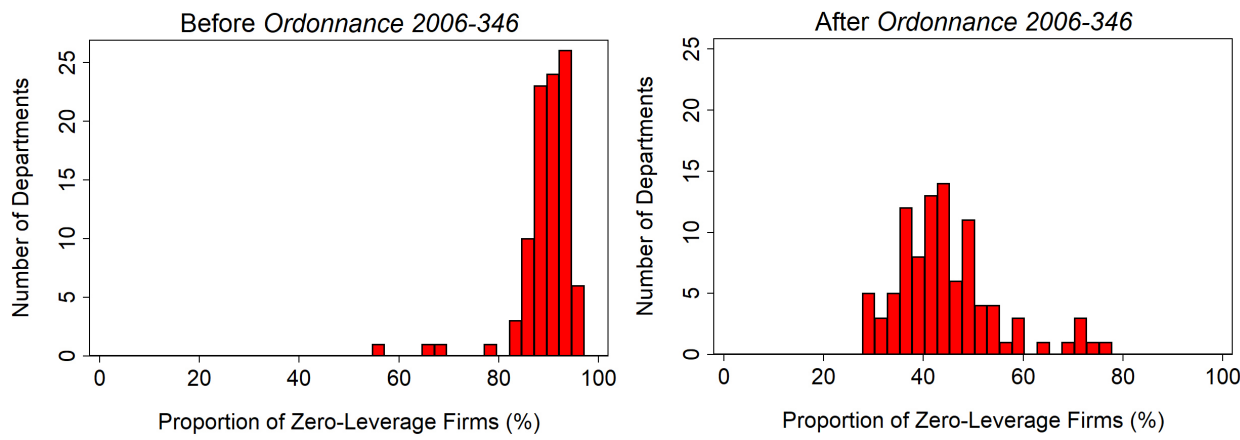

Figure IA.1. The Long-term Leverage Distribution of French Departments Before and After the Reform. The histograms show the distribution of mean long-term leverage and the distribution of the proportion of zero-long-term leverage firms for the 96 French departments and the pre- or post-reform period. The histogram entries are the mean of long-term leverage and the proportion of zero-long-term leverage firms by department and year, separately averaged over the pre-reform and the post-reform years.

shifted the bulk of the proportion of zero-leverage firms distribution to the left (see right-side histogram in Panel B), so that after 2006 most departments registered a mean proportion of zero-leverage firms between $30 \%$ and $50 \%$. Overall, our conclusion is that the collateral reform reshaped the distribution of long-term debt usage across virtually all French departments.

Next, we provide further details and geographical tests on the heat maps showing the increases in long-term leverage (Panel A of Figure 5 in Section IV.A of the paper) and the decreases in the proportion of zero-long-term leverage firms (Panel B) across France.

Spatial-point analysis allows us to determine whether the distribution of an event $s$ in a 
geographic surface $R$ exhibits clustering, as opposed to being random. To identify and measure clustering across the surface $R$, we use the probability density function $\mathrm{p}(s)$ which defines the probability of observing the event $s$ in a certain location within $R$. This function can be estimated by means of non-parametric methods, such as kernel estimations. Kernel estimators generate a spatially-smooth estimate of $\mathrm{p}(s)$ over a fine grid of cells $(g=1,2, \ldots, G)$ covering the surface $R$. Cells in the grid can be arbitrarily-small defined.

In our case, the surface $R$ represents the French European territory. We divide $R$ into 30,000 contiguous cells. Each cell $g$ covers an area that is approximately 20 square kilometers. Next, we define the event $s$ of interest as: (1) companies with large changes in mean long-term leverage (5\% or more); or (2) companies that did not have long-term leverage before the reform, but have positive long-term leverage every year after the reform. For each of the 96 departments that form the French European territory, we compute the frequency of companies that satisfy criterion (1) (alternatively, (2)) and compute the median values of those frequencies across all departments; which are $22 \%$ and $25 \%$ for (1) and (2), respectively.

Next, we identify the geographic coordinates of the "centroids" of the departments that show a frequency value above the median. Centroids are the geographic points at the center of each department and represent the location of event $s$. Figure IA.2 shows that centroids generally correspond to the location of departmental capital cities in France. Based on these coordinates, we use kernel estimations to generate a spatially-smooth estimate of $\mathrm{p}(s)$ over each cell $g$ of the grid covering $R$ (see, e.g., Bailey and Gatrell (1995) and Waller and Gotway (2004)). In other words, we estimate the probability of observing event $s$ of interest across each of the 30,000 cells that cover the French European territory. For each event s, we obtain 


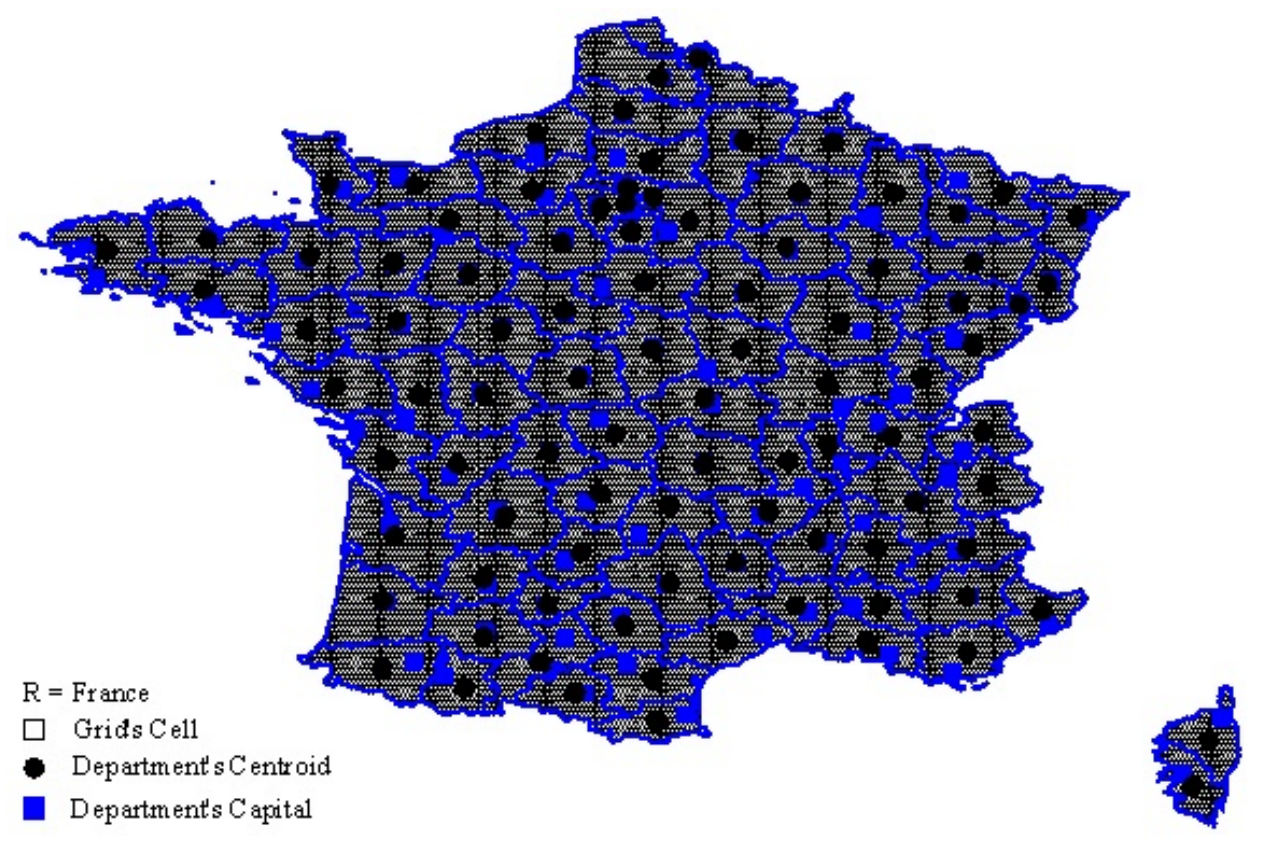

Figure IA.2. Centroids and Capitals across French Departments. The graph shows the surface $R$ corresponding to the French European territory, which is divided in 30,000 (grey-rimmed) cells and 96 (blue-rimmed) departments. Black circles indicate the location of each department's centroids; while blue squares indicate the location of each department's capital city.

a probability distribution that we divide into 20 quantiles, where each quantile is assigned a different color: deeper red (blue) is associated with higher (lower) probability of occurrence of event $s$. Heat maps display the color-coded results of this estimation.

To corroborate our inferences about the reform's effect on debt-taking along the intensive and extensive margins, we calculate the degree of overlapping across the two maps, using the kernel estimates of the probability of occurrence of either large increases in long-term leverage or large decreases in the proportion of zero-long-term leverage firms for each cell in the maps. For each of the 20 quantiles that divide each probability distribution, we calculate the fraction of cells in common across the maps over the total number of cells in the quantile. The higher the fraction, the larger is the degree of overlap between the maps. 


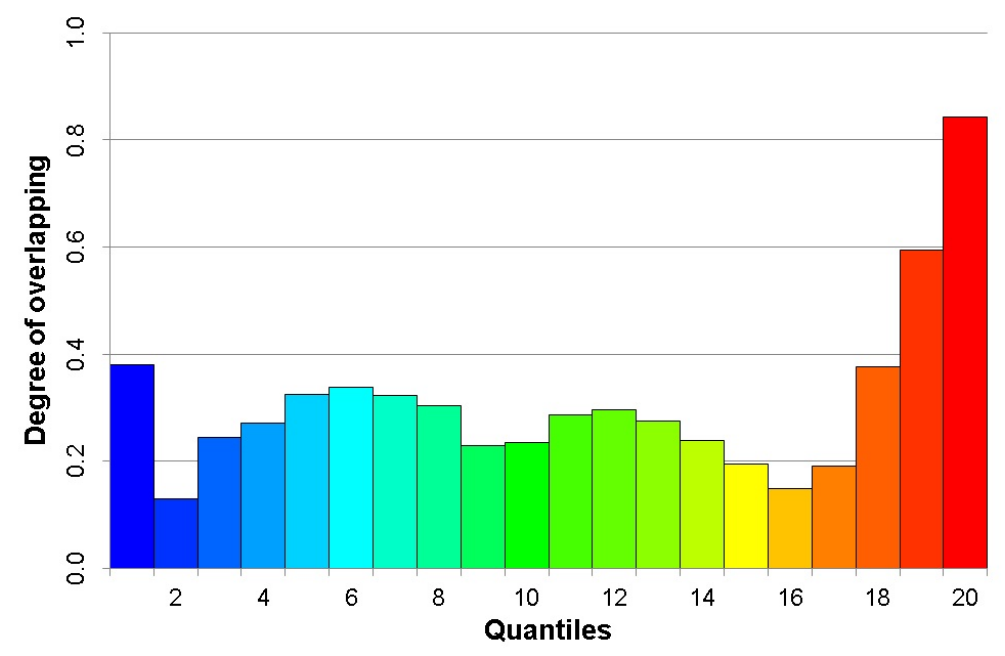

Figure IA.3. Degree of Overlapping between the Maps in Figure 5 (Section IV.A). The graph shows the degree of overlapping between the maps in Panels A and B of Figure 5. The horizontal axis shows the 20 quantiles into which each probability distribution is divided (one for each color in the heat map). The vertical axis reports the fraction of cells in each quantile that are in common across the two maps.

Figure IA.3 shows strong evidence that the largest degree of overlap between the two maps occurs in the deeper red (84\%) and deeper blue (38\%) areas.

Finally, we run one more test related to the heat map of the distribution of firm births across France (Figure 7 in Section V of the paper). This map highlights areas in France where the change in the ratio of start-up businesses per 1,000 workers from pre- to post-reform lies above the top decile across all French departments. To validate the similarities between this map and the map showing increases in long-term debt-taking (Panel A in Figure 5 in Section IV.A in the paper), we run panel data tests. In particular, we identify those departments that are deep red in both maps and compare their increase in new business formation with the increase in new business formation in departments that are deep red in only one of the two 
maps. We estimate the following model on department-level data from INSEE:

$$
Y_{d, t}=\alpha_{d}+\alpha_{t}+\beta \text { Post }_{t} \times \text { Overlapping Department }_{d}+\varepsilon_{d, t},
$$

where $Y$ is the number of new businesses per 1,000 employees for each department $d$ in each year. Post is a dummy equal to one starting from 2006 onwards, else zero. OverlappingDepartment is a dummy equal to one for departments that are deep red in both the map showing increases in long-term debt-taking (Panel A of Figure 5 in the paper) and the map showing firm births (Figure 7) and zero for departments that are deep red in only one of the two maps. Table IA.III shows that the DID estimate on Post $\times$ OverlappingDepartment is almost equal to one (see column 2), suggesting that after the reform the departments with common red areas experienced an increase of one new entry per 1,000 employees relative to the control departments. This result further confirms that those departments observing the largest increases in new business formation were also those observing the largest increases in debt-taking.

\section{TABLE IA.III ABOUT HERE}

\section{IA.IV. Alternative Regression Specifications}

This section includes the results from estimations of alternative specifications of the leverage tests in Table II in the paper, where we run all our estimations on a sample of treated and control firms matched on firm fundamentals. To avoid the concern of endogenous firm 
fundamentals confounding our results ("bad control problem," see Angrist and Pischke (2009, 64-66)), in the paper we use a sample matched on pre-reform characteristics. As an alternative, we rerun those leverage regressions on the full sample, augmenting the model with 2005 control variables interacted with year dummies as follows:

$$
Y_{i, t}=\alpha_{i}+\alpha_{k, t}+\beta \text { Post }_{t} \times \text { Treated }_{i}+\delta_{t}^{\prime} \text { Control }_{i}+\varepsilon_{i, t},
$$

where Control $_{i}$ is a vector of control variables measured in 2005, and the subscript in the $\delta_{t}$ slope coefficient vector indicates that the slope coefficients are allowed to vary over time. The controls are identical to the covariates used to create the PS-matched sample: Size, CompanyAge, Employees, Profitability, and TotalLeverage. Table IA.IV suggests that using control variables interacted with year dummies generates almost the same estimates as in Table II. For example, while the original Post $\times$ Treated estimate in the total long-term leverage regression in column (1) of Table II is 0.026 , the corresponding estimate in Table IA.IV is 0.028.

\section{TABLE IA.IV ABOUT HERE}

Next, we dig deeper into the timing of the effects of Ordonnance 2006-346 on debt-taking. To do so, we replicate the tests in Table II of the paper using a more comprehensive set of Post dummy variables. In particular, we run the model:

$$
Y_{i, t}=\alpha_{i}+\alpha_{k, t}+\sum_{q=2002}^{2009} \beta_{q} \text { Post }_{t}^{(q)} \times \text { Treated }_{i}+\varepsilon_{i, t},
$$


where Post $^{(q)}$ is a dummy variable equal to one starting from year $q$ onwards, else zero. Noting that our sample period ranges from 2001 to 2009, the slope coefficient on Post $^{(q)}, \beta_{q}$, can be interpreted as the change in the mean outcome variable value for the treated firms from year $q-1$ to $q$ minus the change in the mean outcome variable value for the control firms over the same period, after accounting for firm- and industry-year-fixed effects. In other words, $\beta_{q}$ is the DID coefficient contrasting only years $q-1$ and $q$. Table IA.V shows that the effects of Ordonnance 2006-346 emerge only in the reform year, 2006, across almost all debt-taking variables.

\section{TABLE IA.V ABOUT HERE}

Finally, we investigate the effect of the collateral reform on net long-term leverage. To this end, we repeat the regression in column (1) of Table II by replacing LongTermLeverage with Cash (column (1)) or NetLongTermLeverage (column (2)). We define NetLongTermLeverage as long-term debt minus cash reserves scaled by total assets. Column (1) of Table IA.VI suggests that the reform did not affect cash balances, with the estimate on Post $\times$ Treated being a highly insignificant -0.003 . Accordingly, column (2) suggests that the reform's effect on net long-term leverage, 0.028 , was virtually identical to its effect on total long-term leverage, 0.026 .

\section{TABLE IA.VI ABOUT HERE}




\section{IA.V. Parallel Trends, Autocorrelation, and Placebo Tests}

This section offers the results from robustness tests omitted from the paper. We first replicate the parallel trends test in Table $\mathrm{X}$ of the paper on the subsamples of firms also studied in our empirical work. Table IA.VII reports the results of these tests for the subsamples of small versus large firms, firms with few versus many employers, young versus old firms, and financially constrained versus unconstrained firms. In line with the full-sample parallel trends tests, there is no evidence to suggest that any of the subsamples violate the parallel trends assumption.

TABLE IA.VII ABOUT HERE

We next address the concern that autocorrelation in the outcome variable can create upward-biased inference levels in DID tests, as shown by Bertrand, Duflo, and Mullainathan (2004). To achieve that goal, we follow these authors and separately average the long-term leverage outcome variable over the pre-reform and post-reform periods. We then repeat our longterm leverage DID regression using the collapsed data. Column (2) of Table IA.VIII suggests that this modification does not materially affect either our estimates or our inference levels.

$\overline{\text { TABLE IA.VIII ABOUT HERE }}$

We finally offer the results from two placebo tests. We start by using the insight that public firms in France only take on secured credit facilities under exceptional circumstances (e.g., when they are in financial distress) to replicate our tests on public firms, expecting 
that their long-term debt-taking is less affected by the reform than the long-term debttaking of private firms. In accordance with our expectations, we find that public firms observed only a slight increase in their long-term leverage from the pre- to the post-reform period, and that there is no evidence to suggest that the increase is driven by high-fixed assets firms. In particular, column (3) of Table IA.VIII offers evidence that high-fixed assets public firms did not benefit more from the reform than low-fixed assets public firms, neither in total nor along the intensive or extensive margins.

We next also run placebo tests on other Napoleonic-Code countries in Europe, including Belgium, Italy, Portugal, and Spain. To this end, we replicate the base case test in column (1) of Table II in the paper using matched data from these countries. Table IA.IX shows that, in line with Figure 9 in the paper, none of these countries observed an either statistically or economically significant increase in long-term debt-taking similar to that we found for France in 2006.

\section{TABLE IA.IX ABOUT HERE}




\section{REFERENCES}

Angrist, Joshua D., and Jörn-Steffen Pischke, 2009, Mostly Harmless Econometrics: An Empiricist's Companion (Princeton University Press, Princeton).

Bailey, Trevor C., and Anthony C. Gatrell, 1995, Interactive Spatial Data Analysis (Routledge, Essex).

Bertrand, Marianne, Esther Duflo, and Sendhil Mullainathan, 2004, How much should we trust differences-in-differences estimates?, Quarterly Journal of Economics 119, 249-275.

Waller, Lance A., and Carol A. Gotway, 2004, Applied Spatial Statistics for Public Health Data (Wiley, Hoboken). 


\section{Table IA.I}

\section{The Effect of the Collateral Reform on Leverage: Difference-in-Differences Matching Estimations Excluding Firms with More than 150 Employees}

This table shows the results from the following model estimation:

$$
Y_{i, t}=\alpha_{i}+\alpha_{k, t}+\beta \text { Post }_{t} \times \text { Treated }_{i}+\varepsilon_{i, t},
$$

where $Y$ is: the long-term leverage ratio (columns (1)-(2)), a no long-term debt dummy (column (3)), the short-term leverage ratio (columns (4)-(5)), or a no short-term debt dummy (column (6)). Post is a dummy equal to one starting from 2006 onwards, else zero. Treated is a dummy equal to one for firms with a 2005 fixed-to-total assets ratio in the top quartile, else zero. $\alpha_{i}$ and $\alpha_{k, t}$ indicate firm-fixed and industry-year-fixed effects, respectively. The "Intensive Margin" ("Extensive Margin") regressions in columns (2) and (5) (columns (3) and (6)) exclude firms with zero (firms with positive) pre-reform debt. All regressions exclude firms with more than 150 employees in 2005. The regressions are run on propensity-score-matched samples using 2005 values of size, age, number of employees, profitability, and total leverage as covariates. Each treated firm is matched with one unique control firm. T-statistics (in parentheses) are calculated from standard errors clustered at the firm level.

\begin{tabular}{|c|c|c|c|c|c|c|}
\hline & \multicolumn{3}{|c|}{$\begin{array}{l}\text { Long-Term Leverage } \\
\text { (Treated by the Reform) }\end{array}$} & \multicolumn{3}{|c|}{$\begin{array}{l}\text { Short-Term Leverage } \\
\text { (Not Treated by the Reform) }\end{array}$} \\
\hline & Total & $\begin{array}{l}\text { Intensive } \\
\text { Margin }\end{array}$ & $\begin{array}{l}\text { Extensive } \\
\text { Margin }\end{array}$ & Total & $\begin{array}{l}\text { Intensive } \\
\text { Margin }\end{array}$ & $\begin{array}{l}\text { Extensive } \\
\text { Margin }\end{array}$ \\
\hline & (1) & (2) & (3) & (4) & (5) & (6) \\
\hline Post $\times$ Treated & $\begin{array}{l}0.027^{* * * *} \\
(12.36)\end{array}$ & $\begin{array}{l}0.010^{* *} \\
(2.15)\end{array}$ & $\begin{array}{l}-0.126^{* * *} \\
(-9.83)\end{array}$ & $\begin{array}{r}0.001 \\
(0.63)\end{array}$ & $\begin{array}{l}0.001 \\
(0.62)\end{array}$ & $\begin{array}{l}-0.022 \\
(-0.62)\end{array}$ \\
\hline Adj.R-squared & 0.09 & 0.03 & 0.35 & 0.01 & 0.01 & 0.05 \\
\hline Observations & 64,047 & 16,829 & 47,218 & 64,047 & 61,314 & 2,733 \\
\hline
\end{tabular}


Table IA.II

\section{The Effect of the Collateral Reform on Leverage: Difference-in-Differences Matching Estimations Using the Distance to Factoring Companies as Identification Strategy}

Panel A of this table shows the results from the following model estimation:

$$
Y_{i, t}=\alpha_{i}+\alpha_{k, t}+\beta \text { Post }_{t} \times \text { Treated }_{i}^{\text {NoFactor }}+\varepsilon_{i, t},
$$

while Panel B shows the results from the model estimation:

$$
\begin{aligned}
Y_{i, t} & =\alpha_{i}+\alpha_{k, t}+\beta \text { Post }_{t} \times \text { Treated }_{i}^{\text {HighFixedAssets }} \\
& +\gamma \text { Post }_{t} \times \text { Treated }_{i}^{\text {NoFactor }} \times \text { Treated }_{i}^{\text {HighFixedAssets }}+\varepsilon_{i, t},
\end{aligned}
$$

where $Y$ is: the long-term leverage ratio (columns (1)-(2)), a no long-term debt dummy (column (3)), the short-term leverage ratio (columns (4)-(5)), or a no short-term debt dummy (column (6)). Post is a dummy equal to one starting from 2006 onwards, else zero. Treated $^{\text {NoFactor }}$ is a dummy equal to one for firms located in postal code areas without factoring companies, else zero. Treated ${ }^{\text {HighFixedAssets }}$ is a dummy equal to one for firms with a 2005 fixed-to-total assets ratio in the top quartile, else zero. $\alpha_{i}$ and $\alpha_{k, t}$ indicate firm-fixed and industry-year-fixed effects, respectively. The "Intensive Margin" ("Extensive Margin") regressions in columns (2) and (5) (columns (3) and (6)) exclude firms with zero (firms with positive) pre-reform debt. All regressions are run on propensity-score-matched samples using 2005 values of size, age, number of employees, profitability, and total leverage as covariates.

\begin{tabular}{|c|c|c|c|c|c|c|}
\hline & \multicolumn{3}{|c|}{$\begin{array}{l}\text { Long-Term Leverage } \\
\text { (Treated by the Reform) }\end{array}$} & \multicolumn{3}{|c|}{$\begin{array}{c}\text { Short-Term Leverage } \\
\text { (Not Treated by the Reform) }\end{array}$} \\
\hline & Total & $\begin{array}{l}\text { Intensive } \\
\text { Margin }\end{array}$ & $\begin{array}{l}\text { Extensive } \\
\text { Margin }\end{array}$ & Total & $\begin{array}{l}\text { Intensive } \\
\text { Margin }\end{array}$ & $\begin{array}{l}\text { Extensive } \\
\text { Margin }\end{array}$ \\
\hline & (1) & (2) & (3) & (4) & (5) & (6) \\
\hline \multicolumn{7}{|c|}{ Panel A: Factoring Company Identification Strategy } \\
\hline Post $\times$ Treated $^{\text {NoF Factor }}$ & $\begin{array}{l}0.009^{* * *} \\
(5.68)\end{array}$ & $\begin{array}{r}0.002 \\
(0.57)\end{array}$ & $\begin{array}{l}-0.121^{* * *} \\
(-11.93)\end{array}$ & $\begin{array}{l}0.003^{*} \\
(1.67)\end{array}$ & $\begin{array}{l}0.003^{*} \\
(1.66)\end{array}$ & $\begin{array}{l}-0.062^{* *} \\
(-2.01)\end{array}$ \\
\hline Adj. R-squared & 0.05 & 0.02 & 0.34 & 0.01 & 0.01 & 0.09 \\
\hline Observations & 87,679 & 24,746 & 62,933 & 87,679 & 84,271 & 3,408 \\
\hline
\end{tabular}
Each treated firm is matched with one unique control firm. $T$-statistics (in parentheses) are calculated from standard errors clustered at the firm level. 
Table IA.II

The Effect of the Collateral Reform on Leverage: Difference-in-Differences

Matching Estimations Using the Distance to Factoring Companies as Identification Strategy (cont.)

\begin{tabular}{|c|c|c|c|c|c|c|}
\hline & \multicolumn{3}{|c|}{$\begin{array}{l}\text { Long-Term Leverage } \\
\text { (Treated by the Reform) }\end{array}$} & \multicolumn{3}{|c|}{$\begin{array}{c}\text { Short-Term Leverage } \\
\text { (Not Treated by the Reform) }\end{array}$} \\
\hline & Total & $\begin{array}{l}\text { Intensive } \\
\text { Margin }\end{array}$ & $\begin{array}{l}\text { Extensive } \\
\text { Margin }\end{array}$ & Total & $\begin{array}{l}\text { Intensive } \\
\text { Margin }\end{array}$ & $\begin{array}{l}\text { Extensive } \\
\text { Margin }\end{array}$ \\
\hline & (1) & $(2)$ & $(3)$ & (4) & $(5)$ & (6) \\
\hline \multicolumn{7}{|c|}{ Panel B: Fixed Assets and Factoring Company Identification Strategy } \\
\hline $\begin{array}{l}\text { Post } \times \\
\text { Treated }{ }^{\text {HighFixedAssets }}\end{array}$ & $\begin{array}{l}0.019^{* * *} \\
(8.07)\end{array}$ & $\begin{array}{l}0.011^{* *} \\
(1.98)\end{array}$ & $\begin{array}{l}-0.028^{* *} \\
(-2.04)\end{array}$ & $\begin{array}{l}-0.002 \\
(-0.81)\end{array}$ & $\begin{array}{l}-0.002 \\
(-0.95)\end{array}$ & $\begin{array}{l}-0.011 \\
(-0.29)\end{array}$ \\
\hline $\begin{array}{l}\text { Post } \times \\
\text { Treated }{ }^{\text {HighFixedAssets }} \\
\times \text { Treated }^{\text {NoFactor }}\end{array}$ & $\begin{array}{l}0.013^{* * *} \\
(4.80)\end{array}$ & $\begin{array}{r}0.000 \\
(0.06)\end{array}$ & $\begin{array}{l}-0.129^{* * *} \\
(-9.09)\end{array}$ & $\begin{array}{r}0.004 \\
(1.54)\end{array}$ & $\begin{array}{r}0.004 \\
(1.58)\end{array}$ & $\begin{array}{l}-0.061 \\
(-1.35)\end{array}$ \\
\hline Adj. R-squared & 0.07 & 0.02 & 0.35 & 0.01 & 0.01 & 0.09 \\
\hline Observations & 87,679 & 24,746 & 62,933 & 87,679 & 84,271 & 3,408 \\
\hline
\end{tabular}

${ }^{* * *},{ }^{* *}$, and ${ }^{*}$ indicate significance at the $99 \%, 95 \%$, and $90 \%$ confidence levels, respectively. 
Table IA.III

The Effect of the Collateral Reform on New Business Entry: Overlap Between the Map Showing Increases in Debt-Taking and the Map Showing Increases in New Business Formation

This table shows the results from the following model estimation:

$$
Y_{d, t}=\alpha_{d}+\alpha_{t}+\beta \text { Post }_{t} \times \text { Overlapping Department }_{d}+\varepsilon_{d, t},
$$

where $Y$ is the number of new businesses per 1,000 employees at the department level. Post is a dummy equal to one starting from 2006 onwards, else zero. OverlappingDepartment is a dummy equal to one for departments that are deep red in both Panel A of Figure 5 (change in long-term leverage) and Figure 7 (change in start-up businesses), and zero for departments that are deep red in either Panel A of Figure 5 or Figure 7. $\alpha_{d}$ and $\alpha_{t}$ are department-fixed and year-fixed effects, respectively. In column (1) the model does not include year-fixed effects. $T$-statistics (in parentheses) are calculated from standard errors clustered at the department level.

\begin{tabular}{lcc}
\hline & Number of New Businesses per 1,000 Employees \\
\hline Post & $(1)$ & $(2)$ \\
Post $\times$ OverlappingDepartment & $2.790^{* * *}$ & \\
& $(37.01)$ & $0.809^{* *}$ \\
\hline Adj.R-squared & & $(2.22)$ \\
Observations & 0.93 & 0.97 \\
\hline
\end{tabular}

${ }^{* * *},{ }^{* *}$, and ${ }^{*}$ indicate significance at the $99 \%, 95 \%$, and $90 \%$ confidence levels, respectively. 
Table IA.IV

\section{The Effect of the Collateral Reform on Leverage: Difference-in-Differences Matching Estimations with Interacted Controls}

This table shows the results from the following model estimation:

$$
Y_{i, t}=\alpha_{i}+\alpha_{k, t}+\beta \text { Post }_{t} \times \text { Treated }_{i}+\delta_{t}^{\prime} \text { Control }_{i}+\varepsilon_{i, t},
$$

where $Y$ is: the long-term leverage ratio (columns (1)-(2)), a no long-term debt dummy (column (3)), the short-term leverage ratio (columns (4)-(5)), or a no short-term debt dummy (column (6)). Post is a dummy equal to one starting from 2006 onwards, else zero. Treated is a dummy equal to one for firms with a 2005 fixed-to-total assets ratio in the top quartile, else zero. Control is a vector of control variables, measured in 2005. The control variables include log total assets, log company age, log number of employees, profitability, and total leverage. Profitability is earnings before interest and taxes scaled by assets. Total leverage is the sum of short-term and long-term debt scaled by assets. $\alpha_{i}$ and $\alpha_{k, t}$ indicate firm-fixed and industry-year-fixed effects, respectively. $\delta_{t}$ is a vector of control variable coefficients, which are allowed to change over our sample period. The "Intensive Margin" ("Extensive Margin") regressions in columns (2) and (5) (columns (3) and (6)) exclude firms with zero (firms with positive) pre-reform debt. $T$-statistics (in parentheses) are calculated from standard errors clustered at the firm level.

\begin{tabular}{|c|c|c|c|c|c|c|}
\hline & \multicolumn{3}{|c|}{$\begin{array}{l}\text { Long-Term Leverage } \\
\text { (Treated by the Reform) }\end{array}$} & \multicolumn{3}{|c|}{$\begin{array}{c}\text { Short-Term Leverage } \\
\text { (Not Treated by the Reform) }\end{array}$} \\
\hline & Total & $\begin{array}{c}\text { Intensive } \\
\text { Margin }\end{array}$ & $\begin{array}{c}\text { Extensive } \\
\text { Margin }\end{array}$ & Total & $\begin{array}{c}\text { Intensive } \\
\text { Margin }\end{array}$ & $\begin{array}{c}\text { Extensive } \\
\text { Margin }\end{array}$ \\
\hline & (1) & (2) & (3) & (4) & (5) & (6) \\
\hline Post $\times$ Treated & $\begin{array}{l}0.028^{* * *} \\
(19.37)\end{array}$ & $\begin{array}{l}0.015^{* * *} \\
(5.02)\end{array}$ & $\begin{array}{l}-0.134^{* * *} \\
(-16.62)\end{array}$ & $\begin{array}{r}0.005 \\
(1.59)\end{array}$ & $\begin{array}{c}0.004 \\
(1.23)\end{array}$ & $\begin{array}{l}-0.039 \\
(-1.58)\end{array}$ \\
\hline Adj. R-squared & 0.08 & 0.05 & 0.29 & 0.27 & 0.28 & 0.06 \\
\hline Observations & 208,953 & 57,812 & 151,141 & 208,953 & 199,036 & 9,917 \\
\hline
\end{tabular}

\footnotetext{
${ }^{* * *},{ }^{* *}$, and ${ }^{*}$ indicate significance at the $99 \%, 95 \%$, and $90 \%$ confidence levels, respectively.
} 
Table IA.V

The Effect of the Collateral Reform on Leverage: Difference-in-Differences

Matching Estimations Showing the Change in the Difference in Long-Term Leverage Between High- and Low-Fixed Assets Firms By Sample Year

This table shows the results from the following model estimation:

$$
Y_{i, t}=\alpha_{i}+\alpha_{k, t}+\sum_{q=2002}^{2009} \beta_{q} \text { Post }_{t}^{(q)} \times \text { Treated }_{i}+\varepsilon_{i, t}
$$

where $Y$ is the long-term leverage ratio (columns (1)-(2)) and a no long-term debt dummy (column (3)). Post ${ }^{(q)}$ is a dummy equal to one starting from year $q$ onwards, else zero. Treated is a dummy equal to one for firms with a 2005 fixed-to-total assets ratio in the top quartile, else zero. $\alpha_{i}$ and $\alpha_{k, t}$ indicate firm-fixed and industry-year-fixed effects, respectively. The "Intensive Margin" ("Extensive Margin") regression in column (2) (column (3)) excludes firms with zero (firms with positive) pre-reform debt. All regressions are run on propensity-score-matched samples using 2005 values of size, age, number of employees, profitability, and total leverage as covariates. Each treated firm is matched with one unique control firm. T-statistics (in parentheses) are calculated from standard errors clustered at the firm level.

\begin{tabular}{|c|c|c|c|}
\hline & \multicolumn{3}{|c|}{ Long-Term Leverage } \\
\hline & Total & $\begin{array}{l}\text { Intensive } \\
\text { Margin }\end{array}$ & $\begin{array}{l}\text { Extensive } \\
\text { Margin }\end{array}$ \\
\hline & (1) & $(2)$ & (3) \\
\hline Post $^{(2002)} \times$ Treated & $\begin{array}{r}0.001 \\
(0.66)\end{array}$ & $\begin{array}{r}0.004 \\
(0.74)\end{array}$ & $\begin{array}{l}-0.000 \\
(-0.17)\end{array}$ \\
\hline Post $^{(2003)} \times$ Treated & $\begin{array}{r}0.001 \\
(0.55)\end{array}$ & $\begin{array}{r}0.003 \\
(0.59)\end{array}$ & $\begin{array}{l}-0.000 \\
(-0.06)\end{array}$ \\
\hline Post $^{(2004)} \times$ Treated & $\begin{array}{l}-0.002 \\
(-1.64)\end{array}$ & $\begin{array}{l}-0.007 \\
(-1.26)\end{array}$ & $\begin{array}{r}0.002 \\
(0.86)\end{array}$ \\
\hline Post $^{(2005)} \times$ Treated & $\begin{array}{r}0.001 \\
(0.47)\end{array}$ & $\begin{array}{r}0.003 \\
(0.51)\end{array}$ & $\begin{array}{l}-0.000 \\
(-0.03)\end{array}$ \\
\hline Post ${ }^{(2006)} \times$ Treated & $\begin{array}{l}0.027^{* * *} \\
(13.74)\end{array}$ & $\begin{array}{l}0.014^{* * *} \\
(3.20)\end{array}$ & $\begin{array}{l}-0.124^{* * *} \\
(-9.76)\end{array}$ \\
\hline Post $^{(2007)} \times$ Treated & $\begin{array}{r}0.001 \\
(0.62)\end{array}$ & $\begin{array}{l}-0.001 \\
(-0.29)\end{array}$ & $\begin{array}{l}-0.003 \\
(-0.24)\end{array}$ \\
\hline Post $^{(2008)} \times$ Treated & $\begin{array}{l}-0.004 \\
(-1.55)\end{array}$ & $\begin{array}{l}-0.002 \\
(-0.35)\end{array}$ & $\begin{array}{l}0.031^{* * *} \\
(3.01)\end{array}$ \\
\hline Post $^{(2009)} \times$ Treated & $\begin{array}{l}-0.001 \\
(-0.37)\end{array}$ & $\begin{array}{l}-0.008 \\
(-1.44)\end{array}$ & $\begin{array}{r}0.010 \\
(0.91)\end{array}$ \\
\hline Adj. R-Squared & 0.07 & 0.02 & 0.34 \\
\hline Observations & 89,826 & 25,470 & 64,356 \\
\hline
\end{tabular}

${ }^{* * *},{ }^{* *}$, and ${ }^{*}$ indicate significance at the $99 \%, 95 \%$, and $90 \%$ confidence levels, respectively. 
Table IA.VI

\section{The Effect of the Collateral Reform on Cash and Net Leverage: Difference-in-Differences Matching Estimations}

This table shows the results from the following model estimation:

$$
Y_{i, t}=\alpha_{i}+\alpha_{k, t}+\beta \text { Post }_{t} \times \text { Treated }_{i}+\varepsilon_{i, t},
$$

where $Y$ is the cash-to-total assets ratio in column (1) and the long-term debt minus cash-to-total assets ratio in column (2). Post is a dummy equal to one starting from 2006 onwards, else zero. Treated is a dummy equal to one for firms with a 2005 fixed-to-total assets ratio in the top quartile, else zero. $\alpha_{i}$ and $\alpha_{k, t}$ indicate firm-fixed and industry-year-fixed effects, respectively. All regressions are run on propensity-score-matched samples using 2005 values of size, age, number of employees, profitability, and total leverage as covariates. Each treated firm is matched with one unique control firm. T-statistics (in parentheses) are calculated from standard errors clustered at the firm level.

\begin{tabular}{lcc}
\hline & Cash & $\begin{array}{c}\text { Net } \\
\text { Long-Term } \\
\text { Leverage }\end{array}$ \\
\hline Post $\times$ Treated & $(1)$ & $(2)$ \\
\hline Adj. R-Squared & $\begin{array}{c}-0.003 \\
(-1.49)\end{array}$ & $\begin{array}{c}0.028^{* * *} \\
(11.03)\end{array}$ \\
Observations & 0.01 & 0.03 \\
\hline$* * *, * *$, and ${ }^{*}$ indicate significance at the $99 \%, 95 \%$, and $90 \%$ confidence levels, respectively.
\end{tabular}




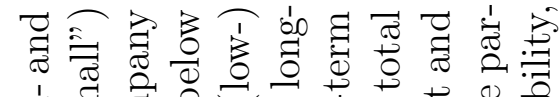

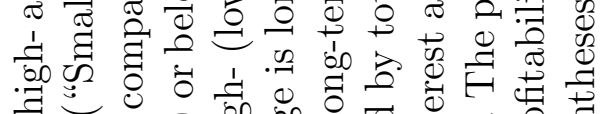
罂 品 प

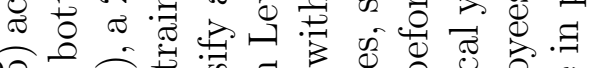

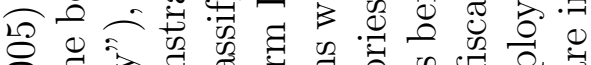

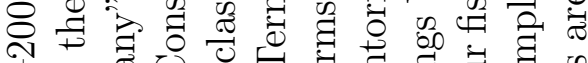

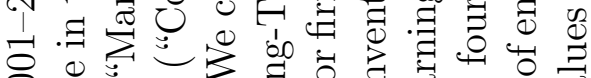

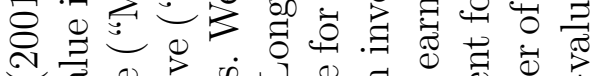

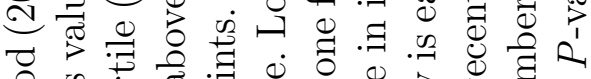

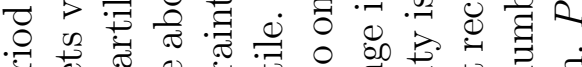

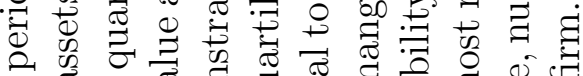
元

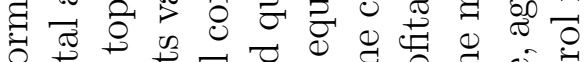

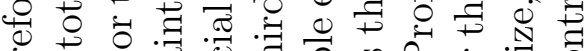

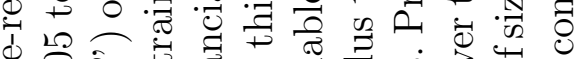

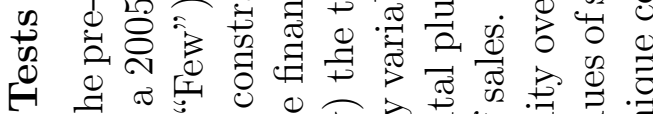

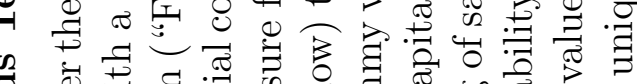

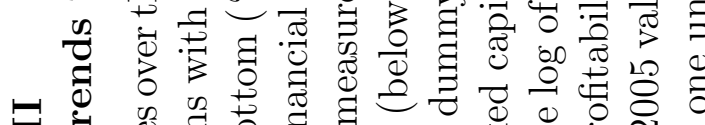

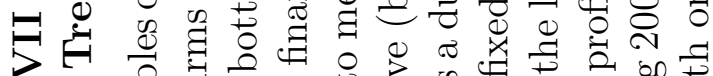

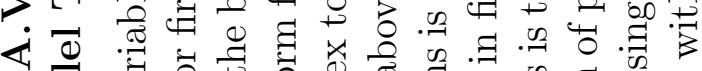

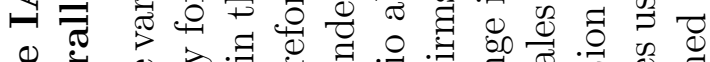
을

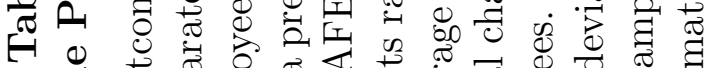

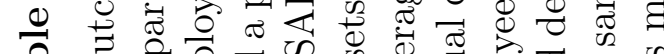
宗 $\overline{0}$ : द्वै क की जू

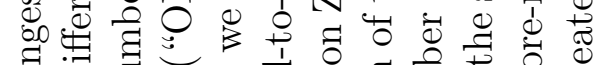

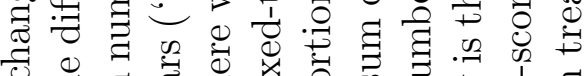

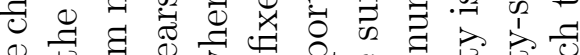
ఫ $\exists \square$

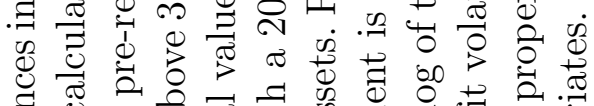
ॠ $\approx$ ๙

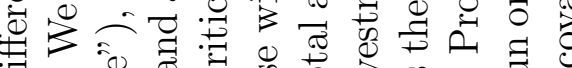
$=\dot{0}$ :

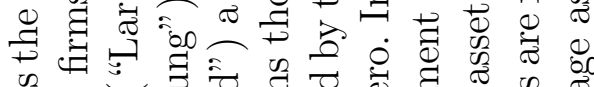
n क

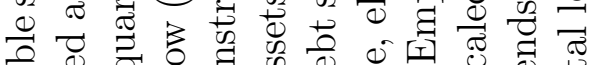

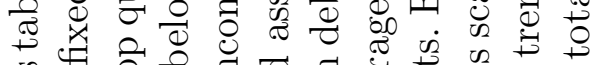

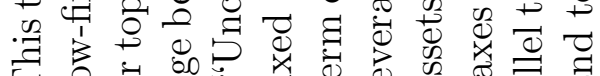

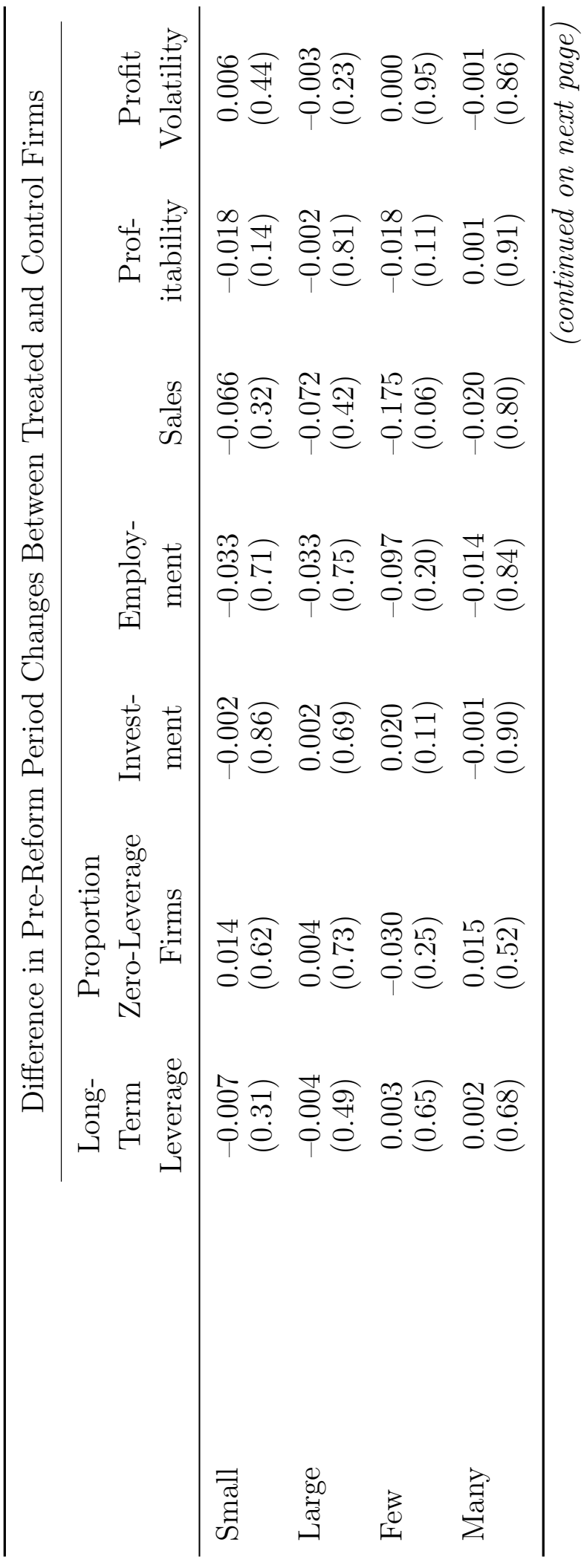




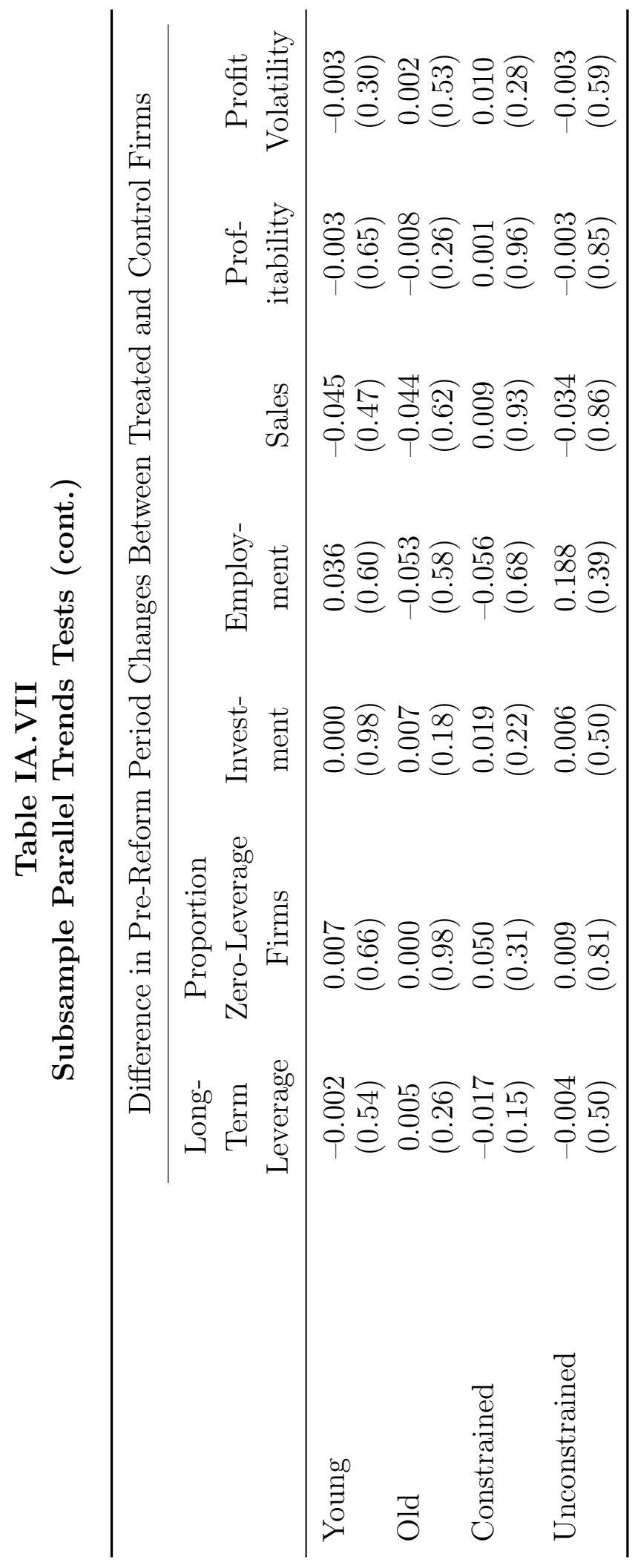


Table IA.VIII

Robustness and Placebo Tests: Difference-in-Differences Matching Estimations

This table shows the results from the following model estimation:

$$
Y_{i, t}=\alpha_{i}+\alpha_{k, t}+\beta \text { Post }_{t} \times \text { Treated }_{i}+\varepsilon_{i, t},
$$

where $Y$ is the long-term leverage ratio (Panels A and B) and a no long-term debt dummy (Panel C). Post is a dummy equal to one starting from 2006 onwards, else zero. Treated is a dummy equal to one for firms with a 2005 fixed-to-total assets ratio in the top quartile, else zero. $\alpha_{i}$ and $\alpha_{k, t}$ indicate firm-fixed and industry-year-fixed effects, respectively. The "Intensive Margin" ("Extensive Margin") regressions in Panel B (Panel C) exclude firms with zero (firms with positive) pre-reform debt. All regressions are run on propensity-score-matched samples using 2005 values of size, age, number of employees, profitability, and total leverage as covariates. Each treated firm is matched with one unique control firm. In the column titled "Base Case (Reference)," we repeat the base-case estimation results from Table II in the paper. In the column titled "Collapsed Data (Robustness Test)," we separately average a firm's analysis variable values over the pre- and the post-reform period before estimation. In the column titled "Public Firms (Placebo Tests)," we repeat the base case estimation on the sample of public French firms. $T$-statistics (in parentheses) are calculated from standard errors clustered at the firm level.

\begin{tabular}{lccc}
\hline & $\begin{array}{c}\text { Base Case } \\
(\text { Reference })\end{array}$ & $\begin{array}{c}\text { Collapsed Data } \\
\text { (Robustness Test) }\end{array}$ & $\begin{array}{c}\text { Public Firms } \\
\text { (Placebo Test) }\end{array}$ \\
\hline Panel A: Total Long-Term Leverage & $(1)$ & $(3)$ \\
\hline Post $\times$ Treated & $0.026^{* * *}$ & $0.026^{* * *}$ & 0.003 \\
\hline Panel B: Intensive Margin & $(14.54)$ & $(14.73)$ & $(0.08)$ \\
\hline Post $\times$ Treated & $0.011^{* * *}$ & & 0.004 \\
\hline Panel C: Extensive Margin & $(2.98)$ & $(2.40)$ & $(0.12)$ \\
\hline Post $\times$ Treated & $-0.108^{* * *}$ & $-0.112^{* * *}$ & 0.000 \\
\hline
\end{tabular}

\footnotetext{
${ }^{* * *},{ }^{* *}$, and ${ }^{*}$ indicate significance at the $99 \%, 95 \%$, and $90 \%$ confidence levels, respectively.
} 
Table IA.IX

\section{Placebo Country Regressions: Difference-in-Differences Matching Estimations}

This table shows the results from the following model estimation:

$$
Y_{i, t}=\alpha_{i}+\alpha_{k, t}+\beta \text { Post }_{t} \times \text { Treated }_{i}+\varepsilon_{i, t},
$$

estimated on firms from the following four Napoleonic-Code countries: Belgium, Italy, Portugal, and Spain. $Y$ is the long-term leverage ratio. Post is a dummy equal to one starting from 2006 onwards, else zero. Treated is a dummy equal to one for firms with a 2005 fixed-to-total assets ratio in the top quartile, else zero. $\alpha_{i}$ and $\alpha_{k, t}$ indicate firm-fixed and industry-year-fixed effects, respectively. All regressions are run on propensity-score-matched samples using 2005 values of size, age, number of employees, profitability, and total leverage as covariates. Each treated firm is matched with one unique control firm. T-statistics (in parentheses) are calculated from standard errors clustered at the firm level.

\begin{tabular}{lrrrr}
\hline & Belgium & \multicolumn{1}{c}{ Italy } & Portugal & \multicolumn{1}{c}{ Spain } \\
\hline Post $\times$ Treated & $\begin{array}{c}-0.008 \\
(-1.60)\end{array}$ & $\begin{array}{r}-0.003 \\
(-1.31)\end{array}$ & $\begin{array}{r}0.017 \\
(0.70)\end{array}$ & $\begin{array}{r}-0.003 \\
(-1.04)\end{array}$ \\
\hline Adj. R-Squared & 0.01 & 0.01 & 0.01 & 0.01 \\
Observations & 23,244 & 70,281 & 1,852 & 80,872 \\
\hline
\end{tabular}

